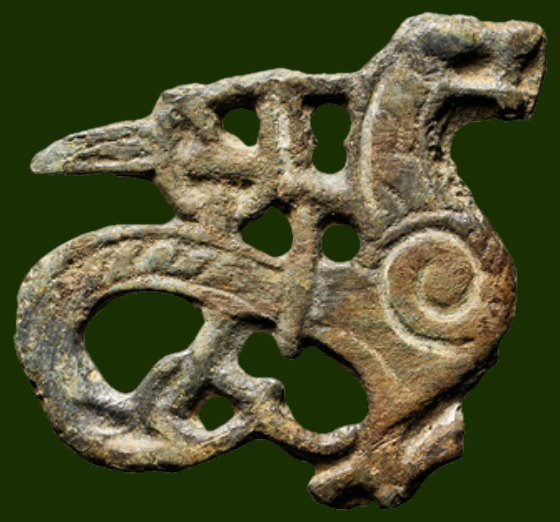

KUML

2016 


\section{KUML 2016}

Årbog for Jysk Arkæologisk Selskab

With summaries in English

I kommission hos Aarhus Universitetsforlag 


\title{
Algade 9 i Aalborg Husenes udvikling fra vikingetid til nutid
}

\author{
Af CHRISTIAN VRÆNGMOSE JENSEN OG CHRISTIAN KLINGE
}

I 2007 blev et af Aalborgs æeldste huse revet ned, hvilket gav Nordjyllands Historiske Museum mulighed for at udgrave en $135 \mathrm{~m}^{2}$ stor flade midt i byen. Kulturlagstykkelsen var op til $4 \mathrm{~m}$, og dateringsrammen går fra Aalborgs opståen i vikingetiden og frem til 1574, året hvor det bindingsværkshus, der indtil 2007 stod på grunden, blev opført. Grunden viste sig at have været bebygget gennem næsten hele perioden, og et af hovedresultaterne af udgravningen er derfor en sekvens på i alt 19 huse med dateringer fra slutningen af 900-tallet til 1574.

Udgravningen resulterede i et af Danmarks bedste fund af byhuse fra vikingetiden og middelalderen, idet anlæggene er veldaterede dendrokronologisk. Der var gode bevaringsforhold for organisk materiale generelt. Desuden havde grunden været næsten kontinuerligt bebygget, hvorved det var muligt at følge udviklingen i bygningernes udformning og indretning fra vikingetidens krumvæggede langhuse, over træhuse med rette langvægge og bilæggerovne i middelalderens første del til senmiddelalderen og renæssancens fuldt udviklede bindingsværkshuse.

I denne artikel fokuseres på de mange hustomters konstruktion, datering og anvendelse, ligesom deres udvikling vil blive sat i forhold til andre fund af lignende huse. Resultaterne af de relevante naturvidenskabelige undersøgelser er medtaget i husbeskrivelserne. Husene gennemgås kronologisk i artiklens katalog, hvor der også findes udgravningsplaner af alle husene.

\section{Bebyggelsens udvikling}

Algade er Aalborgs ældste gade. Den har været hovedgade igennem hele byens historie, og alle de ældste spor efter bymæssig bebyggelse ligger i umiddelbar nærhed af Algade. ${ }^{1}$ Algade 9 ligger på den østlige side af Østerå og var i det meste af middelalderen nabo til byens gråbrødrekloster (fig. 1). Grunden lå 


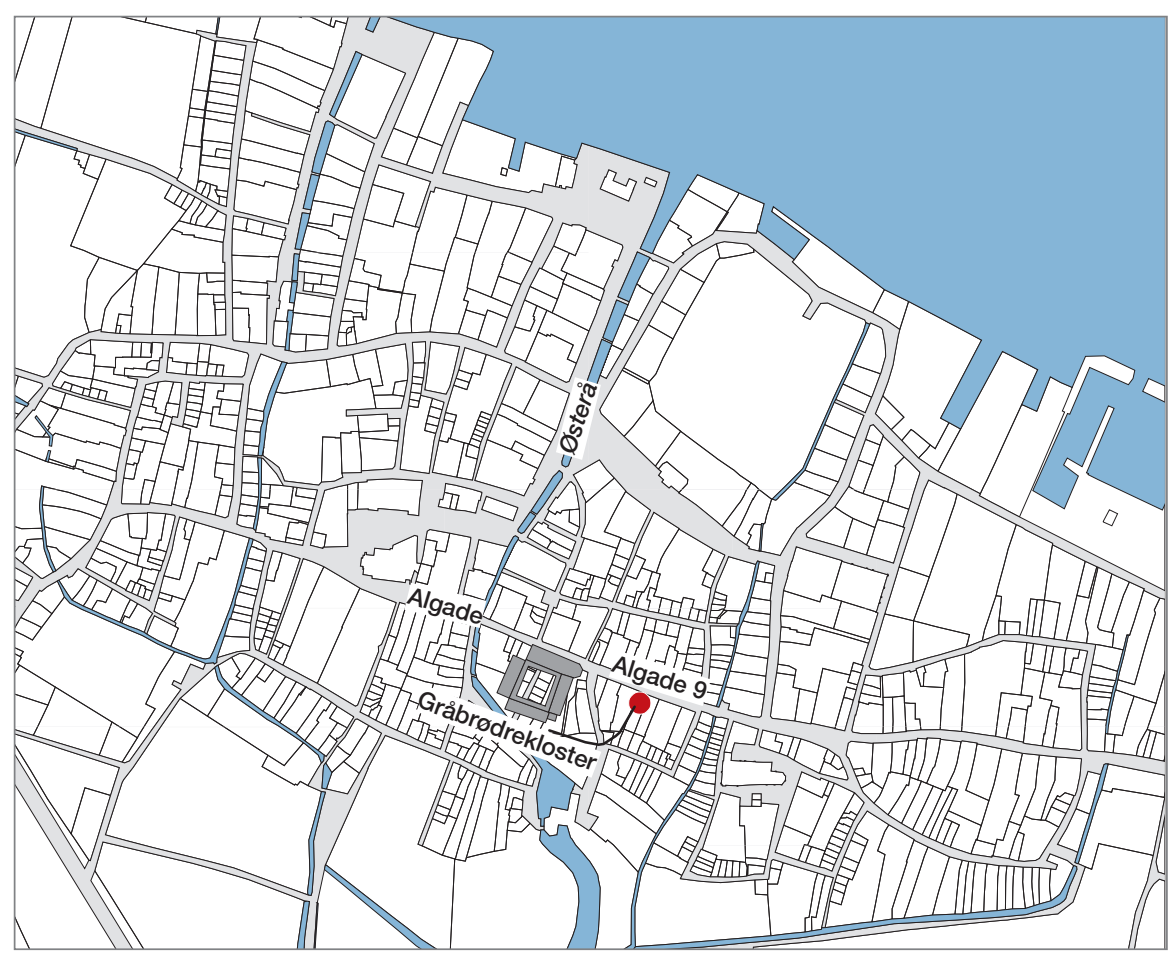

Fig. 1. Udgravningens placering i Aalborg. Baggrundskortet er en digital udgave af et matrikelkort fra 1872, der viser gadeplan og åløb, som det sandsynligvis også så ud ved middelalderens slutning.

Location of the excavation site in Aalborg. The background is a digital version of a cadastral map from 1872, which shows the street layout and river as it probably also appeared at the end of the Middle Ages.

midt i middelalderbyens centrum, og de relativt store huse sandsynliggør, at beboerne har tilhørt den bedrestillede del af Aalborgs befolkning.

De ældste beboelseshuse i Algade 9 blev anlagt i slutningen af 900 -tallet. De overlejrede dog ældre anlæg fra 700-800-tallet såsom grubehuse og en næsten $4 \mathrm{~m}$ bred grøft eller voldgrav. ${ }^{2}$ Bebyggelsens karakter i den ældste vikingetid skal dog ikke diskuteres her. Fra slutningen af 900-tallet er det sikkert, at der er tale om en bymæssig bebyggelse (fig. 2).

Der blev undersøgt rester efter 19 huse, hvoraf de 17 var beboelseshuse, mens de to sidste udgjorde henholdsvis en staldbygning og et smedeværksted. Husene var hovedsageligt orienteret med nordgavlen ud til Algade. Fra middelalderens begyndelse er orienteringen som gavlhuse helt konsekvent. Man må derfor formode, at grundene i denne del af Algade allerede fra starten af middelalderen har været smalle gavlhusgrunde. 


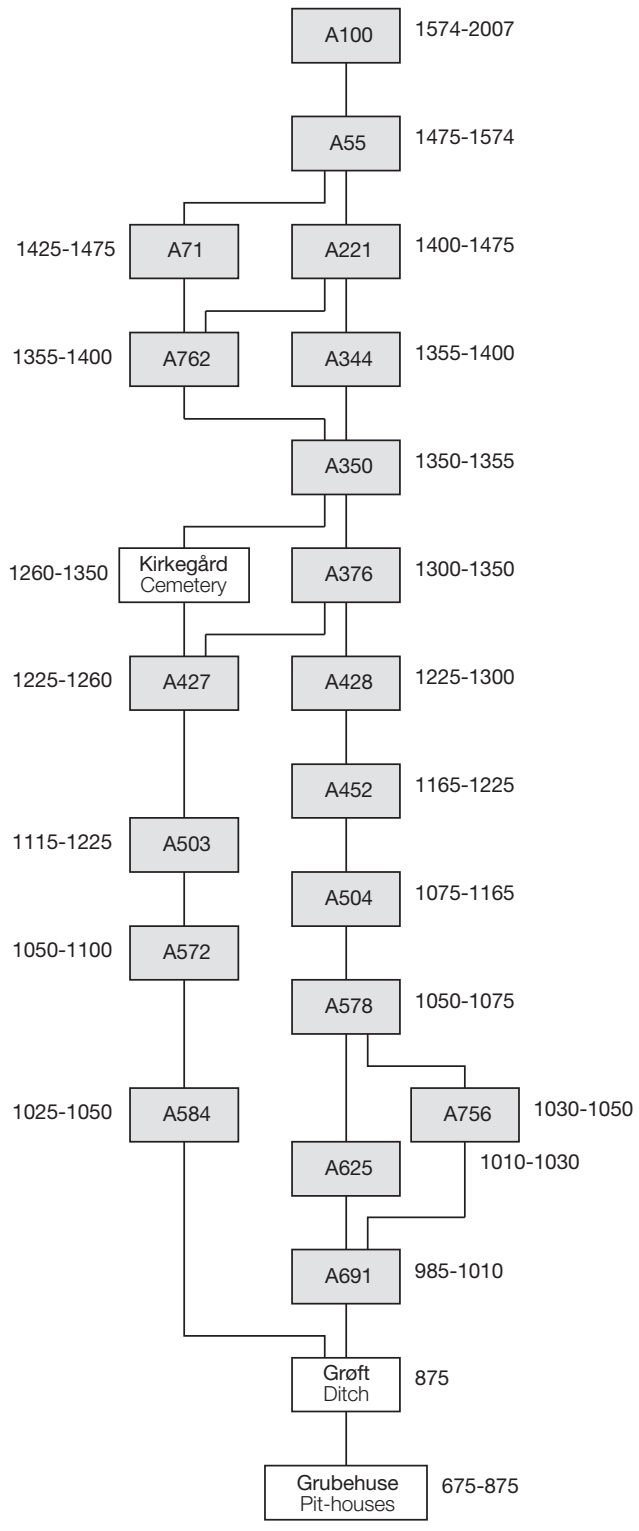

Fig. 2. Matrix med husenes indbyrdes stratigrafi. Husenes omtrentlige levetid er anført.

Matrix showing the stratigraphic relationships between the houses and their approximate lifetimes.

Fra begyndelsen af 1000-tallet var der på den nuværende grund dele af to parceller. Denne opdeling lå ved begyndelsen af middelalderen fast, således at skellet var forskudt ca. $2 \mathrm{~m}$ mod øst i forhold til nutidens matrikelskel. Derfor var der i flere faser rester efter to huse, der havde været i brug samtidigt. Slippen imellem grundene var i begyndelsen af 1000-tallet 2,5 $\mathrm{m}$ bred med husene A584 og A756 på hver side, og den var belagt med vidjefletværk. Slippen blev smallere med tiden, og i begyndelsen af 1200-tallet var den 1,2 m bred og adskilte husene A427 og A428 (fig. 3). 


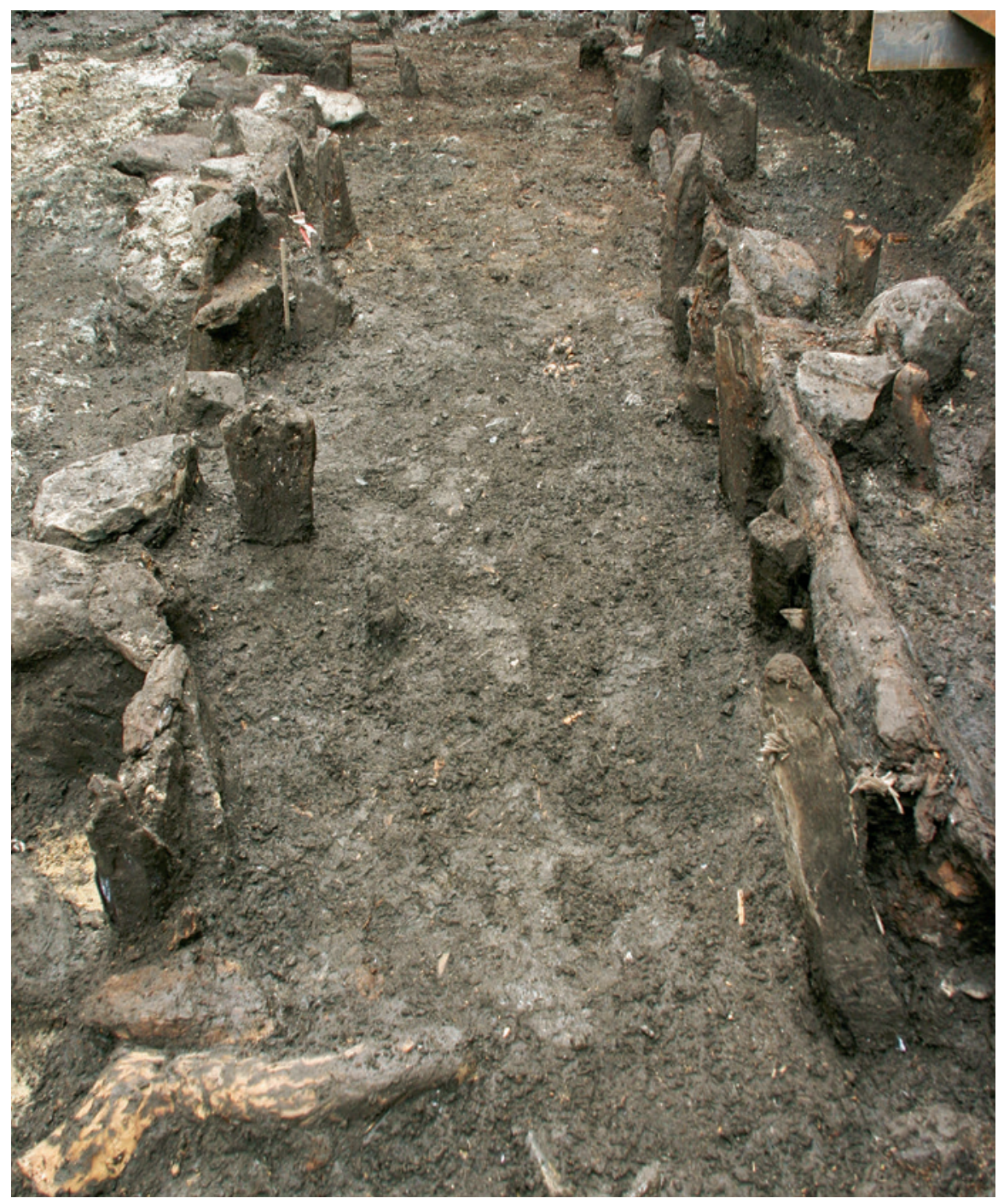

Fig. 3. Slippen imellem hus A427, ca. 1225-1260, og hus A428, ca. 1225-1300, set fra nord. Hus A428 er til venstre. Slippen var 1,2 m bred.

Alley between house A427, c.1225-1260, and house A428, c.1225-1300, seen from the north. House A428 is to the left. The alley was $1.2 \mathrm{~m}$ wide.

I midten af 1200-tallet blev den vestlige grund inddraget til kirkegård for Aalborgs gråbrødrekloster og fungerede som sådan til midten af 1300-tallet. Her fandtes grave, som indeholdt to voksne og to børn. I baggårdsfeltet blev der fundet resterne af et 1,5 m bredt kirkegårdsdige af kampesten, og det har sandsynligvis forløbet helt op til Algade. ${ }^{3}$ 


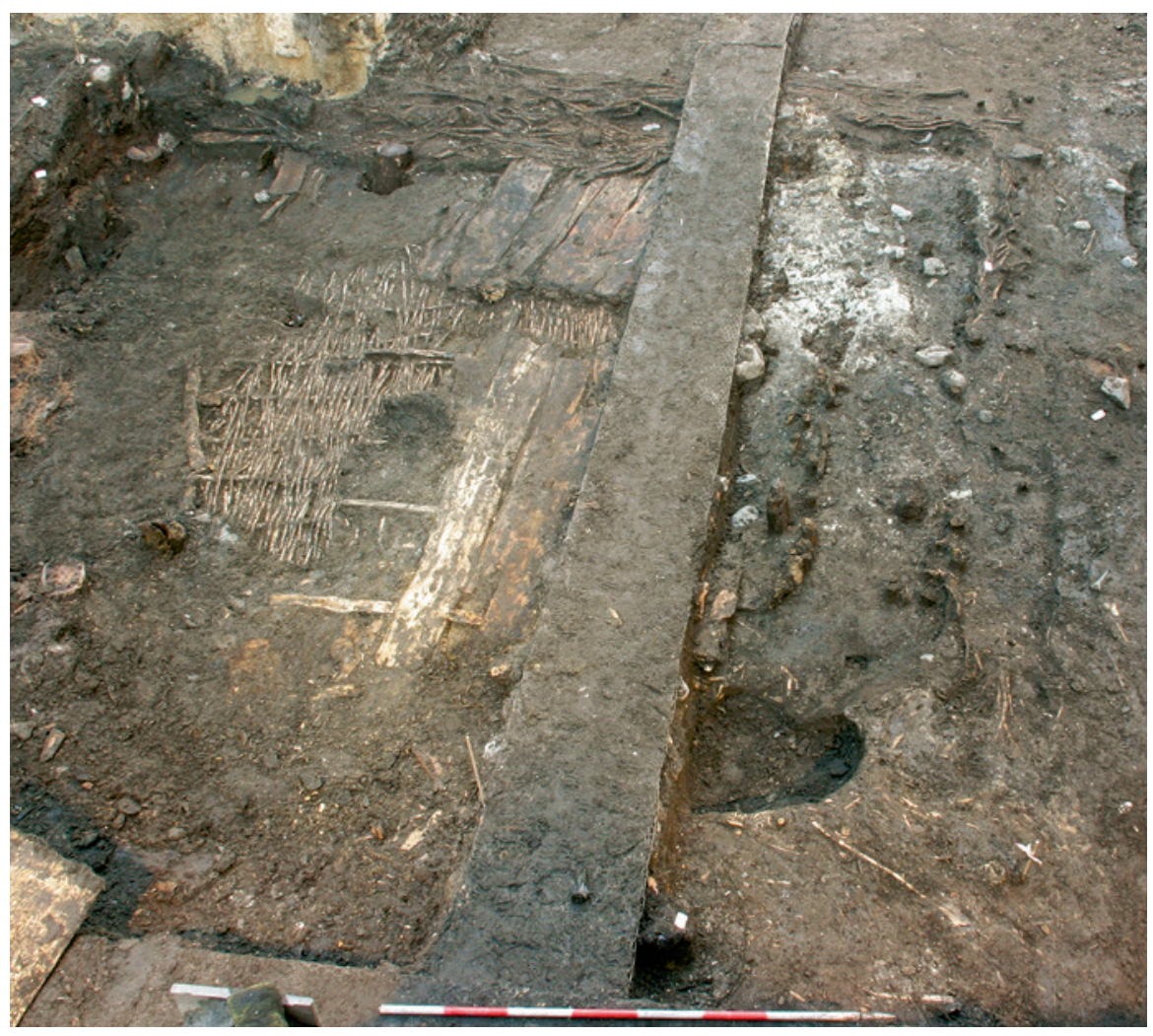

Fig. 4. Hus A350, ca. 1550-1355, set fra syd. Bemærk de fire fletværkshegn, der omkranser huset.

House A350, c. 1550-1355, seen from the south. Note the four wattle fences around the building.

Midt i 1300-tallet saneredes området, og der var en kort periode uden bebyggelse, og klosterkirkegården blev også indskrænket. Generelt skete der en markant ændring i grundstrukturen, en ændring der også ses i andre dele af Aalborg. ${ }^{4}$ Den kan være et resultat af en kortvarig befolkningsnedgang i byen omkring midten af 1300-tallet. Årsagen kan være Den Sorte Død eller en hungersnød i forbindelse med 1300-tallets landbrugskrise. I denne periode, der sandsynligvis ikke var særlig langvarig, lå stalden A350 på den sydlige del af grunden (fig. 4).

Herefter blev den nuværende grundinddeling etableret, og senest fra omkring år 1400 blev arealet igen bebygget med gavlhuse ud til Algade. Det ældste gavlhus var A221, og husene A221, A55 og A100 havde alle omtrent samme bredde og placering på grunden. 


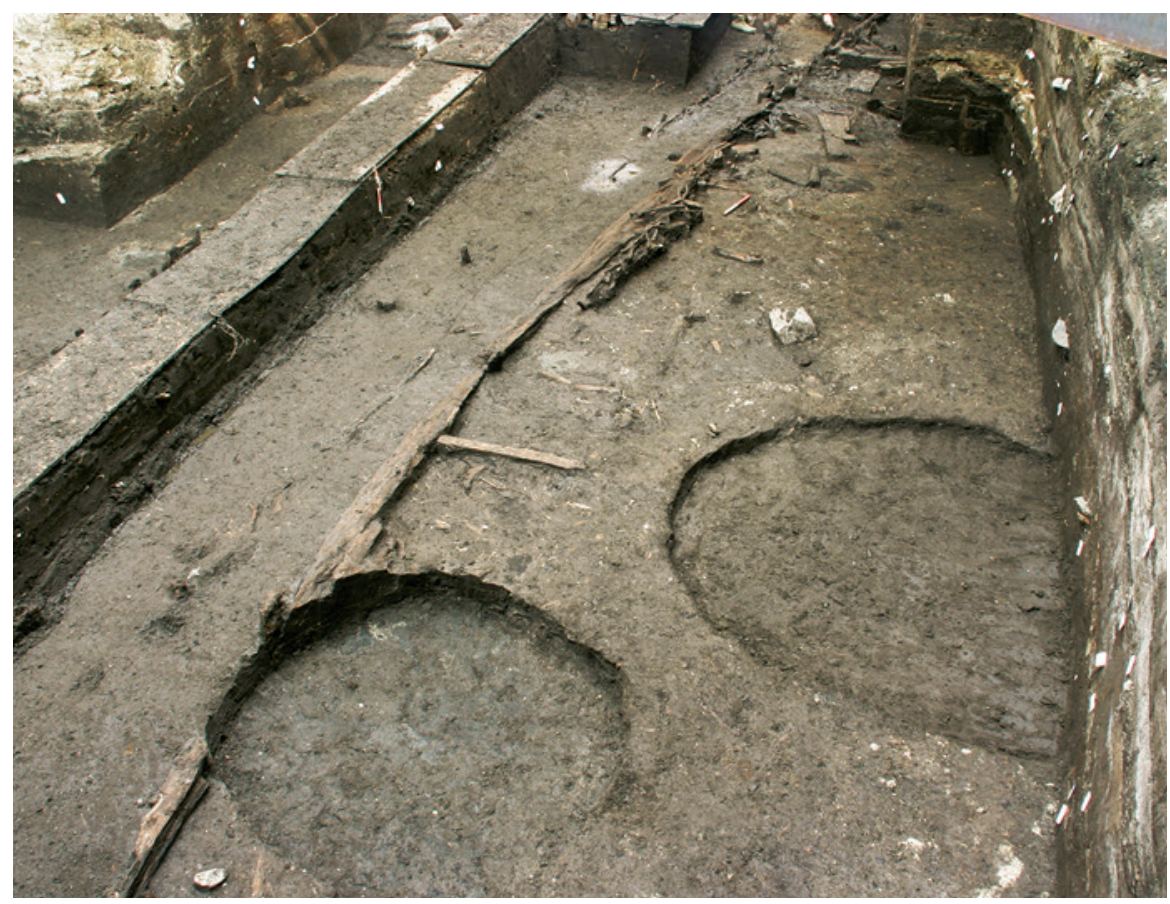

Fig. 5. Hus A578, ca. 1050-1075, set fra syd. De cirkulære forstyrrelser er yngre gruber. House A578, c. 1050-1075, seen from the south. The circular disturbances are later pits.

\section{Krumvæggede langhuse, 900- og 1000-tallet}

De fire ældste huse A691, A657, A625 og A578 (fig. 15-17) fra det sene 900-tal og det meste af 1000-tallet var orienteret nord-syd, mens A584 lå orienteret i øst-vestlig retning. Selvom nord-sydvendte huse forekom i datidens åbne bebyggelser, kan orienteringen i dette tilfælde måske inddrages som et argument for en relativ tæt bebyggelsesstruktur, der skulle respekteres. Til trods for, at ingen af disse tidlige huse kunne udgraves i deres fulde udstrækning, får man alligevel indtryk af huse med en betydelig størrelse. To af husene, A691 og A578, var længere end 15 m og A625 med sikkerhed længere end 10 m. Hus A584 var $4 \mathrm{~m}$ bredt ved gavlen.

Disse fem huse har, så vidt det kunne afgøres, haft langvægge med et krumt forløb (fig. 5). Ved de yngre huse fra slutningen af 1000-tallet var der til gengæld tale om rette langvægge. Skiftet fra krumme til rette langsider synes således at ske ved midten af 1000-tallet eller senest omkring 1075. I en kort periode har de to hustyper stået side om side. Dette ses også i Lund, i PK-bankens fase 1 , fra $1000-1050 .^{5}$ 
Det bevarede tømmer og træ fra husene gør det muligt at beskrive en række forskellige konstruktionsmæssige træk (fig. 6). Det drejer sig særligt om husenes ydervægge i langsiderne. Grundlæggende synes der at have været tale om to forskellige vægtyper. I det ene tilfælde, ved hus A584 og A691, var der tale om en stavværksvæg i en væggrøft. Ved det relativt bedst bevarede A584 var der tale om regulære stavplanker, der vekslede med nærmest utildannede stolper.

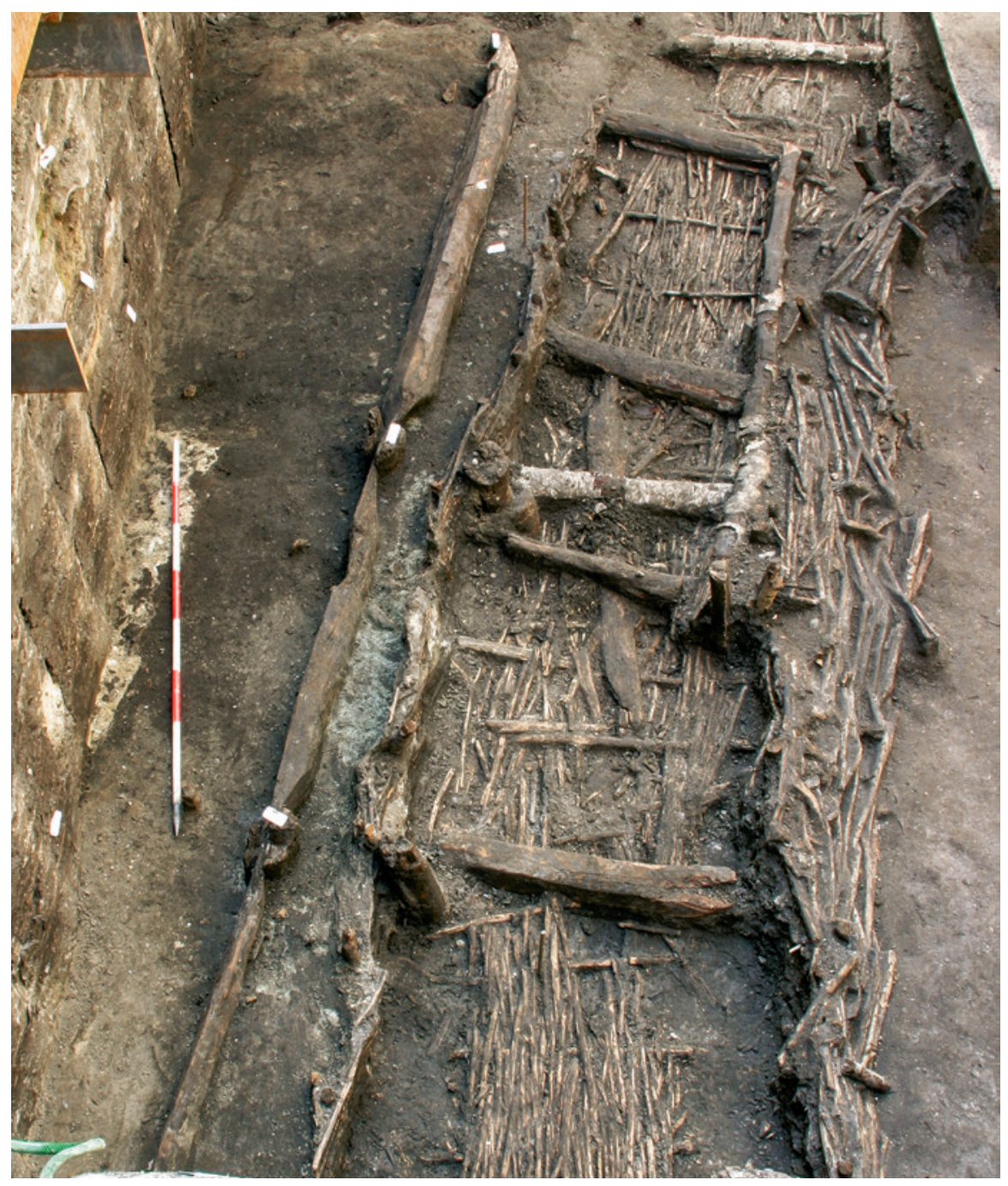

Fig. 6. Hus A756, ca. 1030-1050, set fra nord. Langs huset ses samtidige hegn og en fletværksvej/-sti.

House A756, c. 1030-1050, seen from the north, with coeval fences and a wattle road/ path running alongside. 


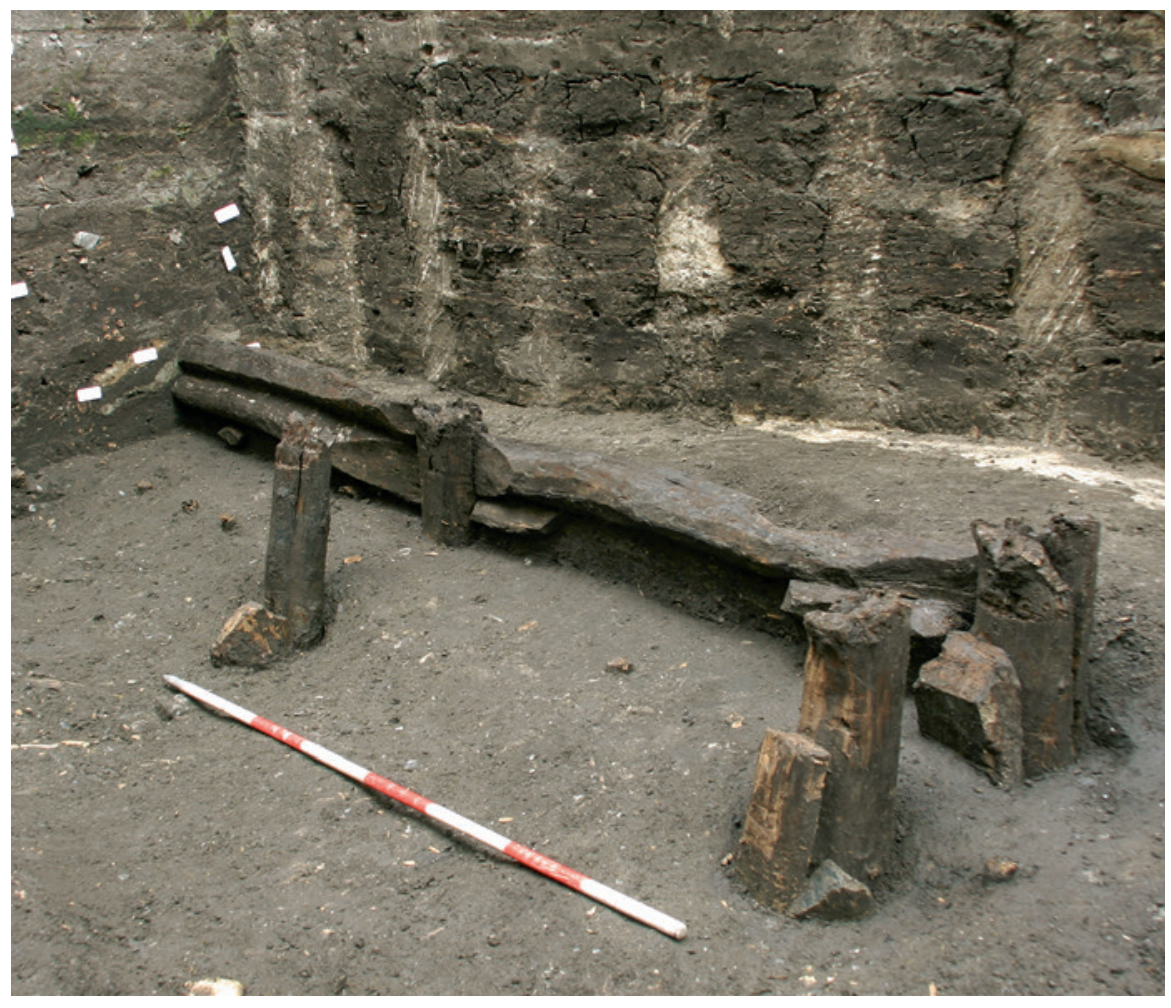

Fig. 7. De to nordligste fag af hus A756, ca. 1030-1050, set fra sydvest. Foran væggen ses to udvendige skråstivere.

The two northernmost bays of house A756, c. 1030-1050, seen from the southwest. Two external, sloping timber buttresses can be seen in front of the wall.

Den anden vægtype sås ved husene A756, A625 og A587, hvor der var tale om en bullignende konstruktion med 2-3 m lange fag. Væggenes stolper har været dobbeltstolper. Det vandrette fyldtømmer udgjordes af kløvede træstammer, der ikke viste nogen videre tilvirkning. Deres ender var dog skråt tilhugget for at kunne indstikkes i dobbeltstolpernes mellemrum (fig. 7).

Desuden har vidjefletværk været benyttet som vægmateriale ved husene A765, A584 og A578. Det drejede sig i det mindste om indvendige vægge og måske rundt om en enkelt gavl. Der blev ikke set spor efter nogen form for klining af disse.

Ved enkelte af dobbeltstolperne i husene A625 og A756 var der bevaret udvendige skråstivere, og vinklingen vidnede om væghøjder, der mindst må have været omkring 2 m. Også et enkelt yngre hus, A503, fra 1100-tallet havde udvendige skråstivere, der dog angav en anelse lavere væghøjde på knap 2 m. 
Forskellige træsorter har været benyttet i de krumvæggede huse, men generelt får man indtryk af ret spinkelt tømmer af en svingende og måske relativ lav kvalitet. Egetømmer har været fremherskende, men el synes at have været flittigt benyttet ved hus A756, mens birk blev set ved hus A578. Der må regnes med et vist genbrug, hvilket både var tydeligt i kraft af den vekslende kvali-

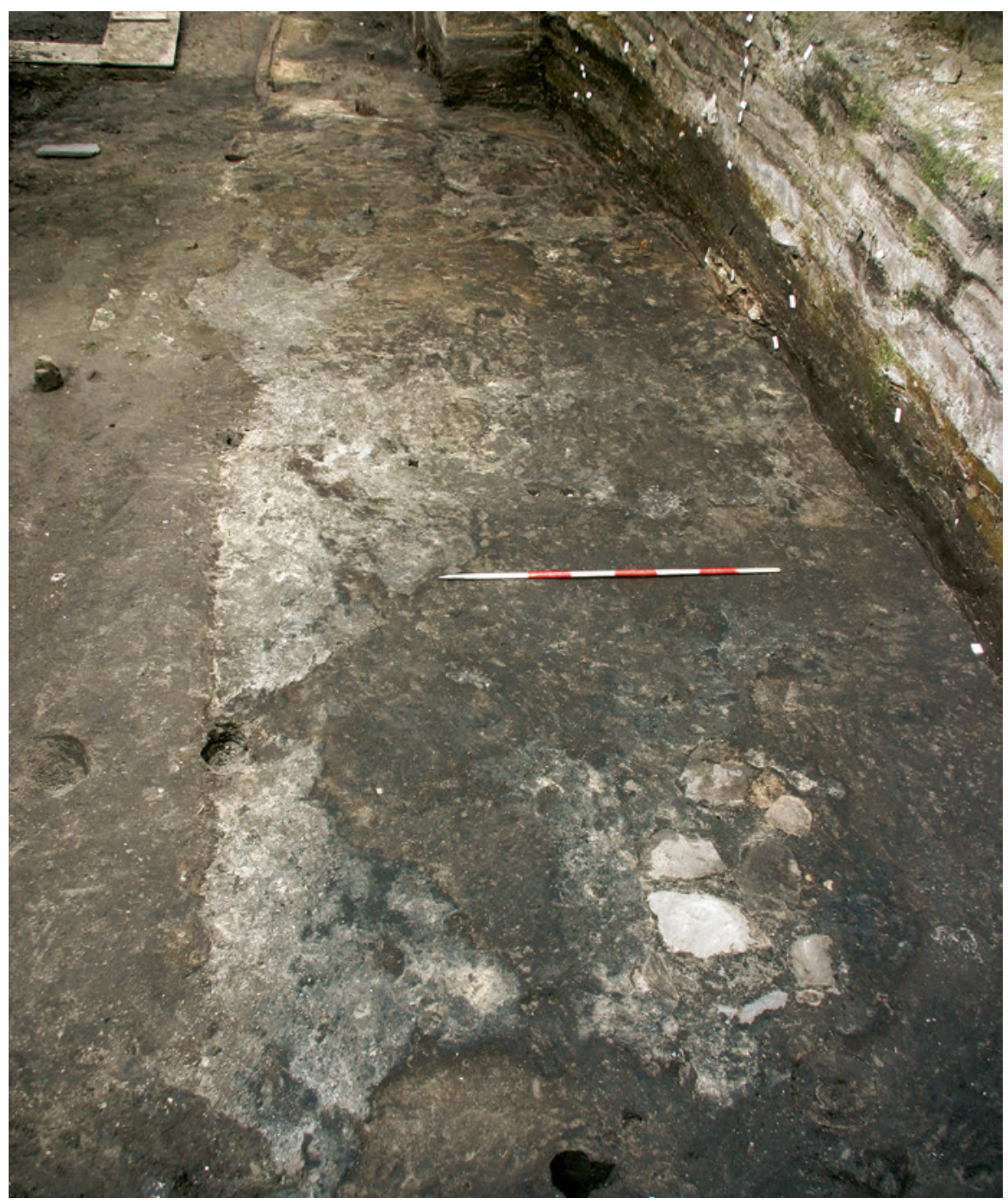

Fig. 8. Hus A625, ca. 1010-1030, set fra syd. I forgrunden ses husets centrale ildsted. I baggrunden anes det samtidige eller lidt yngre hus A756, ca. 1030-1050.

House A625, c. 1010-1030, seen from the south. In the foreground is the house's central hearth. The coeval or slightly later house A756, c. 1030-1050, is just visible in the background. 
tet, men også ved meget forskellig alder på dateret tømmer fra samme væg. Indtrykket af tømmerets relativt ringe kvalitet kan også udvides til at gælde husene fra de efterfølgende århundreder. Isoleret set synes tømmeret altså ikke at tale for et miljø, der har hævet sig op på højeste niveau.

Indre vægforløb sås i enkelte tilfælde ved rester af fletværk eller stolper og stolpehuller. I husene A756, A625 og A578 kunne der anes en rumdeling med et relativt stort centralt rum, flankeret af mindre rum ved gavlene (fig. 8). De påviste ildsteder i husene A691, A625 og A578 lå i dette centrale rum, mens hus A584 havde et ildsted i husets østligste del. Der blev ikke fundet rester af regulære gulve af hverken tørv eller ler, hvorved de adskiller sig fra de yngre huse. I bedste fald har der været tale om ganske tynde sandlag. Hovedsageligt på baggrund af ildstederne tolkes alle fem huse som beboelseshuse, om end noget taler for, at i hvert fald hus A578 på et tidspunkt sidst i sin levetid er brugt som stald.

Husene fra 1000-tallet svarer på mange punkter til lignende bygninger $\mathrm{i}$ Lund og Viborg. Ved PK-banken i Lund synes konstruktionen også at være forholdsvis spinkel med ydre skråtstillede stolper. Disse stolpers vinkel giver, som ved hus A625 og A756, en mulig væghøjde på godt 2 m. ${ }^{6}$ I Store Sct. Pederstræde i Viborg var vægstolpehullerne af varierende dybde og havde en lille diameter. Dette indikerer, at hustomterne I og IV har været af samme karakter som i Algade 9, ligesom de var del af en relativt tæet bebyggelse.?

De krumvæggede huse i Algade 9 må grundlæggende opfattes som varianter af det såkaldte Trelleborghus med et centralt halrum og gavlrum i husenderne. Dateringen af denne hustype er tidligere præsenteret som ca. 950-1050, ${ }^{8}$ hvilket Algade 9-husene ikke ændrede på.

\section{Huse med bilæggerovne, 1100- til 1300-tallet}

De syv huse A572, A504, A503, A452, A427, A428 og A376 dateret til perioden fra slutningen af 1000-tallet og frem til 1300-tallet havde mange fællestræk (fig. 17-21). De var orienteret nord-syd med gavlen ud til Algade, og især de to ældste huse på den østlige del af grunden, A504 og A452, var i særlig grad ens. De to yngre huse, A428 og A367, som blev udgravet i meget højt tempo, mindede meget om A504 og A452.

Langsiderne var rette. Stolperne var dog i flere tilfælde kløvet og tilhugget i fuldkantede rektangulære tømmerstokke som i vikingetiden. Selvom konstruktionerne i husene i øvrigt var forskelligartede, anes en vis udvikling over tid. Syldsten indgik i konstruktionen af husene A452, A427 og A428, men kun ved A452, fra 1160'erne, var stolperne sat på sten. De øvrige huse fra perioden havde 
jordgravede stolper. Syldstenene i A427 og A428, fra begyndelsen af 1200-tallet, blev brugt som fundering for væggen. Ved husene A572, A504, A503 og A452, der er dateret til perioden fra slutningen af 1000-tallet til begyndelsen af 1200-tallet, bestod væggene af jordgravede stavplanker. Der var dog ikke tale om samme type, for mens det ældste hus, A572, havde ensartede $13-25 \mathrm{~cm}$ brede stavplanker, havde det yngre hus A452 planker af meget uens karakter og bredde (fig. 9). Husene fra 1200-tallet, A427 og A428, havde bulvægge lagt på syldsten. Udviklingen synes at være foregået således, at man byggede med stavplanker i den ældste middelalder og gik over til at bruge bulkonstruktioner mod midten af middelalderen.

Der var ligeledes flere meget iøjnefaldende fællestræk ved husenes indretning. Det er derfor nærliggende at tale om én egentlig hustype. Husene A504, A503, A452 og A428 havde alle spor efter tre rum, og det gjaldt muligvis også de resterende tre huse. Det var sandsynligvis kun de to nordlige rum ud mod gaden, der udgjorde beboelsesdelen. Beboelsesrummene var ved husene

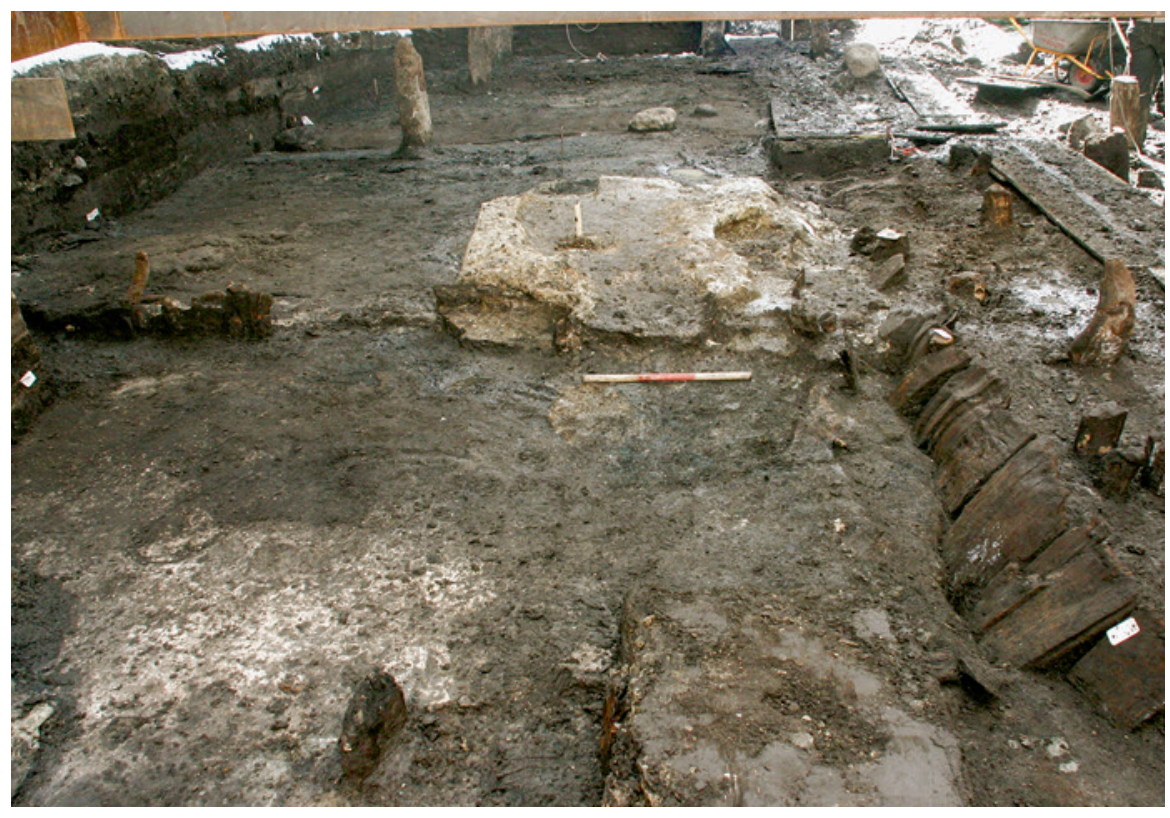

Fig. 9. Et kig fra nord ind i hus A452, ca. 1165-1225. Indfyringen til bilæggerovnen ses til højre lige bag målepinden. Den nordlige skillevæg ses til venstre for ovnen med døråbningen umiddelbart op ad ovnen. Til højre ses væggens stavplanker med uens bredde.

A view from the north into house A452, c. 1165-1225. The stokehole for the jamb stove (i.e. a stove fired from another room) can be seen to the right, behind the scale bar. The northern partition wall is to the left of the stove, with a doorway immediately next to it. The staves of the wall, which vary in width, can be seen to the right. 
A504, A452 og A428 forbundet med en dør i skillevæggen. Det nordlige rum lå ud mod Algade, hvor hovedindgangen efter al sandsynlighed har været. Det bagerste rum havde en ukendt funktion, men kan have været brugt som værksted, hvilket der er spor efter i hus A452.

Det mest markante fællestræk ved hustypen var den meget store ovn op ad den ene ydervæg i det midterste rum. Dette var tilfældet i husene A504, A452, A427, A428 og A376. Ved de to ældste huse, A504 og A452, var der med sikkerhed tale om en bilæggerovn, der blev fyret fra husets nordlige rum (fig. 10 og 11). De øvrige registrerede ildsteder befandt sig alle i rummet mod nord. Det midterste rum har derimod været røgfrit og mere komfortabelt.

Bilæggerovnene var alle opbygget efter samme mønster. En rektangulær base opbygget af ler med størrelser der varierede fra 197-260x103-168 cm. Inde i lerbasen var mindst et indre lag af sten, hvorover et tyndt lag af ler fungerede som brugsflade. Der fandtes typisk flere indre lag af sten, hvilket viser, at ovnene har været nedbrudt og genopbygget flere gange. Ovnkappen var opbygget

Fig. 10. Bilæggerovnen i hus A504, ca. 1075-1165, set fra syd. Brugsfladen er fjernet til det underliggende stenlag. Bunden af det lille anlæg, der tolkes som glødegemme, ses nederst. Øverst til venstre for ovnen ses husets nordlige skillevæg.

Jamb stove in house A504, c. 1075-1165, seen from the south. The working surface has been removed down to the underlying stone layer. The base of the small structure, interpreted as a compartment for embers, is visible at the bottom. To the upper left is the house's northern partition wall.

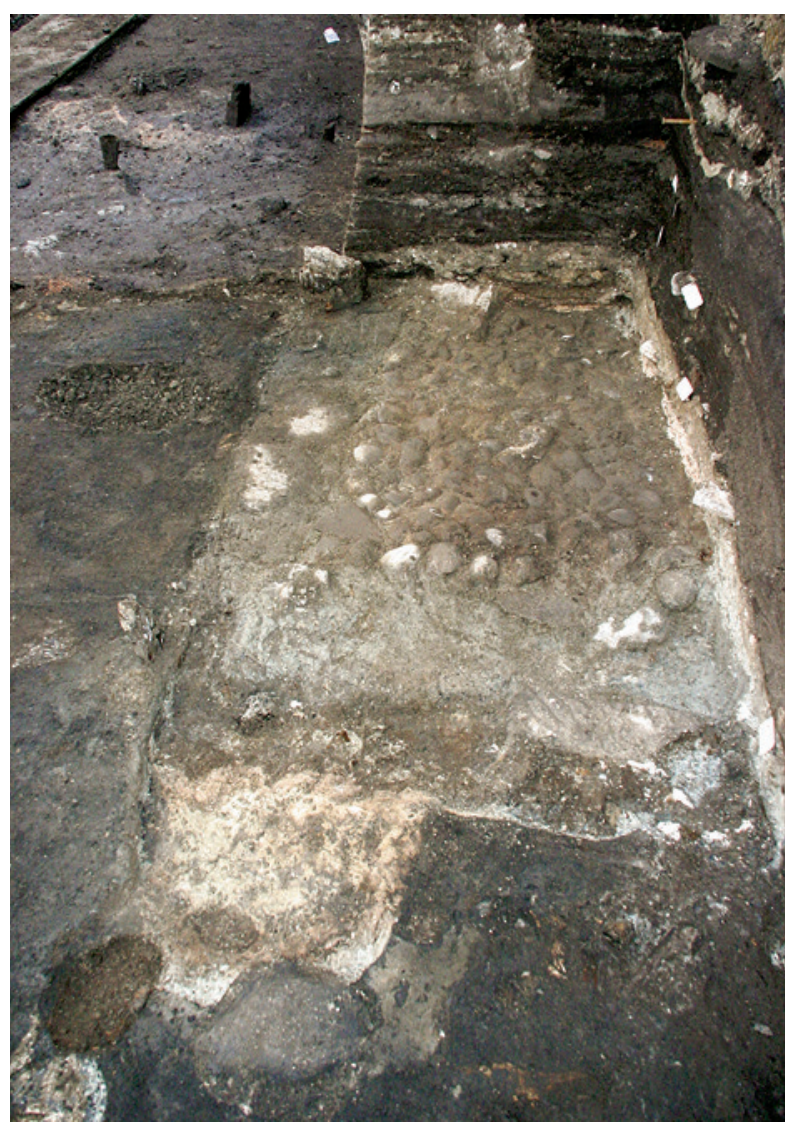




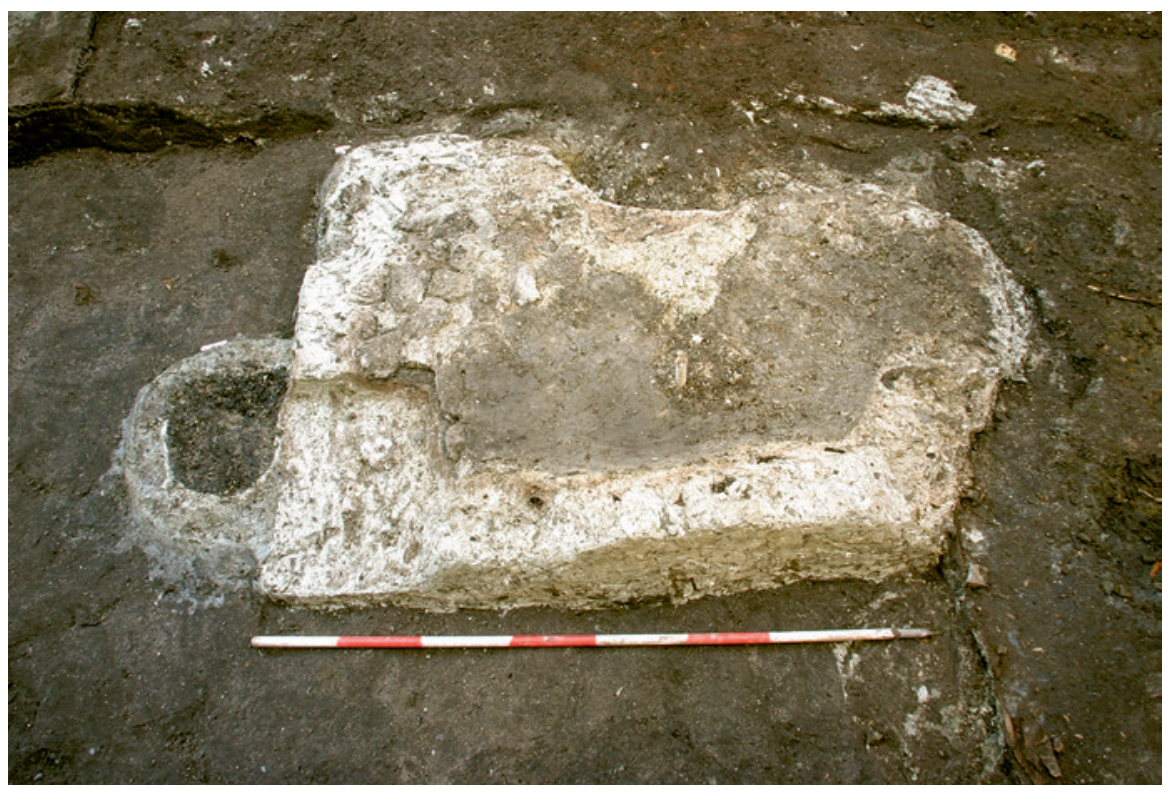

Fig. 11. Bilæggerovnen i hus A452, ca. 1165-1225, set fra øst. Indfyringen ses til højre. Bemærk det lille anlæg til venstre, anlægget tolkes som et glødegemme. Tilsvarende glødegemme ses på fig. 10 .

Jamb stove in house A452, c. 1165-1225, seen from the east. The stokehole can be seen to the right. Note the small structure to the left, interpreted as a compartment for embers. A similar feature is shown in figure 10 .

over et skelet af krydsede vidjer, der var stukket ned i ovnbunden. Bilæggerovne af denne type ser ud til at have været et gennemgående træk ved indretningen af huse i Aalborg fra 1000-tallet og frem til 1300-tallet. ${ }^{9}$ Der kendes yderligere seks andre bilæggerovne fra byen og dateret til samme periode. ${ }^{10}$

Ved A452 og A428 bestod det ældste gulv af to lag rektangulære græstørv, der så ud til at være udlagt, inden huset blev opført.

Denne hustype, der er karakteriseret af to beboelsesrum, hvoraf det ene blev opvarmet med en bilæggerovn, er også blevet identificeret andre steder i byen. ${ }^{11}$ Disse huse fra Aalborg er desuden meget lig nogle huse undersøgt i Store Sct. Pederstræde i Viborg i 1967. De to huse fra Viborg er dateret til tiden omkring 1100 og omkring 1200 og er de eneste øvrige danske eksempler på byhuse med bilæggerovne fra middelalderens første halvdel. ${ }^{12}$ Selvom husene i Viborg ikke var orienteret som gavlhuse, må der være tale om en variation over den samme hustype som i Aalborg. Hustypen skal således ikke blot findes i den tætte gavlhusbebyggelse, men muligvis i flere forskellige områder af byerne. 
Fig. 12. Oversigtsbillede af hus A221, ca. 14001475, set fra syd. På billedet ses pikstensgulvet i kælderen nederst. Øverst ses beboelsesrummet, et af ildstederne kan ses i toppen af balken.

Overview of house A221, c. $1400-1475$, seen from the south. The cellar's cobbled floor can be seen at the bottom. Uppermost is the living room; one of the hearths is visible in the top of the baulk.

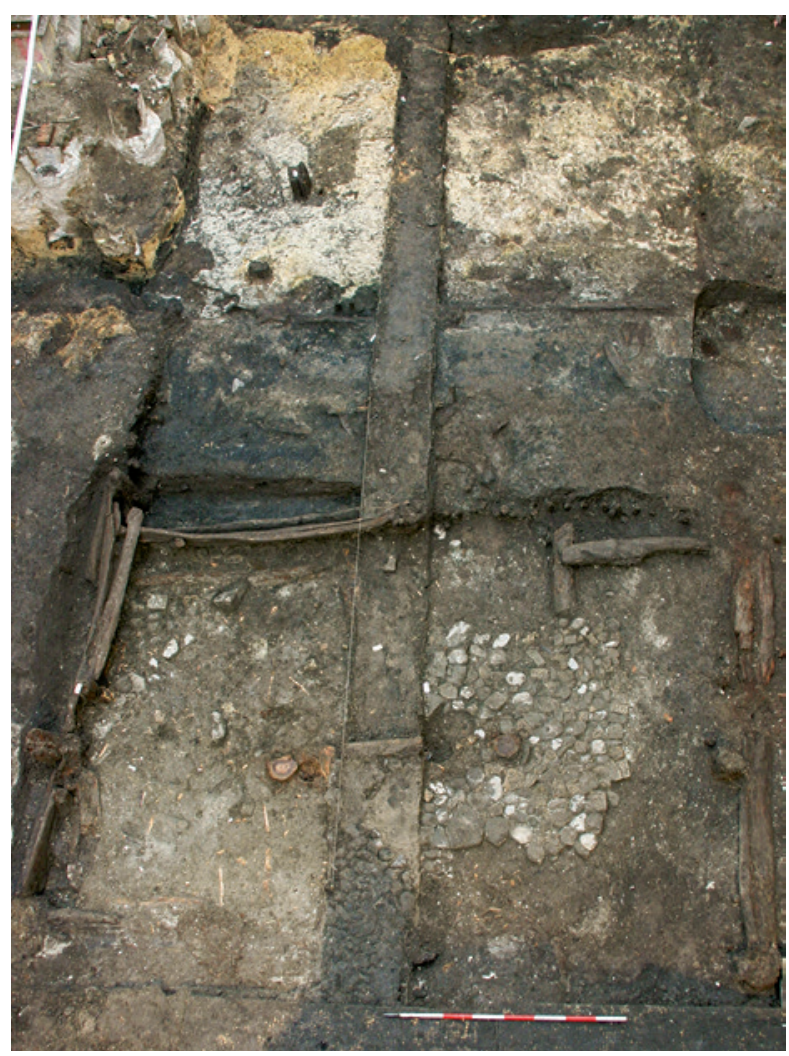

\section{Bindingsværkshuse med kælder, 1400- til 1500-tallet}

Husene A350, A762, A372, A221, A71 og A55 (fig. 22-25) daterer sig til den sidste del af middelalderen og den tidlige renæssance. A350 var en stald fra tiden omkring saneringen af grunden i midten af 1300-tallet. I den følgende fase lå foruden beboelseshuset A762 også smedebygningen A344 på grunden. Hus A762 var dog dårligt bevaret og derfor vanskeligt at sammenligne med de andre. Af hus A71 var der blot spor efter en ydervæg. De to yngste huse, A221 og A55, var begge gavlhuse ligesom det nedrevne hus A100 fra 1574. Husene A221, A71 og A55 har formentlig alle været opført i en eller anden form for bindingsværk.

Det kan være vanskeligt at påvise bindingsværkskonstruktioner arkæologisk, men de to yngste huse, A55 og A71, havde, bortset fra kælderen i A55, ingen jordgravede dele. Det er derfor sandsynligt, at de har været opført i fuldt udviklet bindingsværk. I hus A55 var bevaret enkelte syldsten og formuldede spor af fodremmene. Hus A71 var bygget på en gennemgående syld af tæt udlagte kampesten. Hus A221 havde stolper eller pæle i hele væglinjen (fig. 
12). Stolperne eller pælene i den nordlige del af huset kan have været ført op til tagremmen. En anden mulighed er, at der var tale om piloteringspæle under en fodrem. Dette sås i et samtidigt hus fra Algade 5, der blev udgravet i 2006. Denne fodrem var fuldkantet og hvilede på mindst en piloteringspæl, der var tappet op i fodremmens underside. ${ }^{13}$ Ved hus A221 var oversiden af pælene bortrådnet, og eventuelle tapper kunne derfor ikke påvises. Det er dog sandsynligt, at begge bygninger har været fuldt udviklede bindingsværkshuse.

Husene A221 og A55 var udstyret med en kælder med pikstensgulv under den sydlige del (fig. 13). Kældrene var under en meter dybe, og de havde samme bredde som huset, og var bygget i træ. Begge har sandsynligvis haft samme funktion, idet de havde $80 \mathrm{~cm}$ brede pigstensfrie områder ud mod væggene. Nogle tømmerstykker i disse områder blev tolket som en konstruktion, der har skullet hæve tønder, kar eller lignende op over gulvet. At de var bygget $\mathrm{i}$ træ må være et bevidst valg, da der andre steder i byen ses kældre fra 1400- og 1500-tallet bygget i kampesten og teg. $1 .^{14}$ Det nedrevne hus på Algade 9, A100, havde således en kampestenskælder, som dog lå i den nordlige del af huset ud mod Algade. Det ses andre steder i Aalborg, at de ældre kældre bygget i 1400-tallet lå væk fra gaden, mens kældrene ved yngre huse fra 1500-og 1600 -tallet blev flyttet ud til gaden. ${ }^{15}$

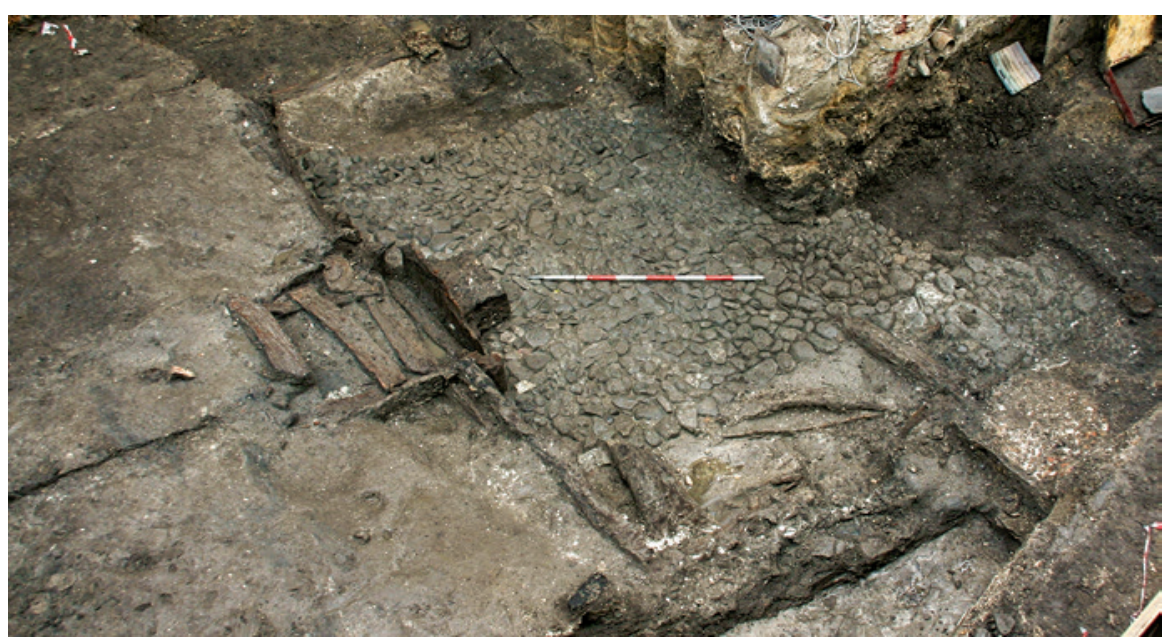

Fig. 13. Kælderen i hus A55, ca. 1475-1574, set fra nordvest. Kældertrappen og den lukkede kælderdør ses midtfor til venstre. Bemærk pikstensgulvet, der ikke er lagt helt ud til kælderens ydervægge.

The cellar in house A55, c. 1475-1574, seen from the northwest. The cellar steps and the closed cellar door can be seen centre left. Note the cobbled floor, which has not been laid all the way out to the cellar's outer walls. 


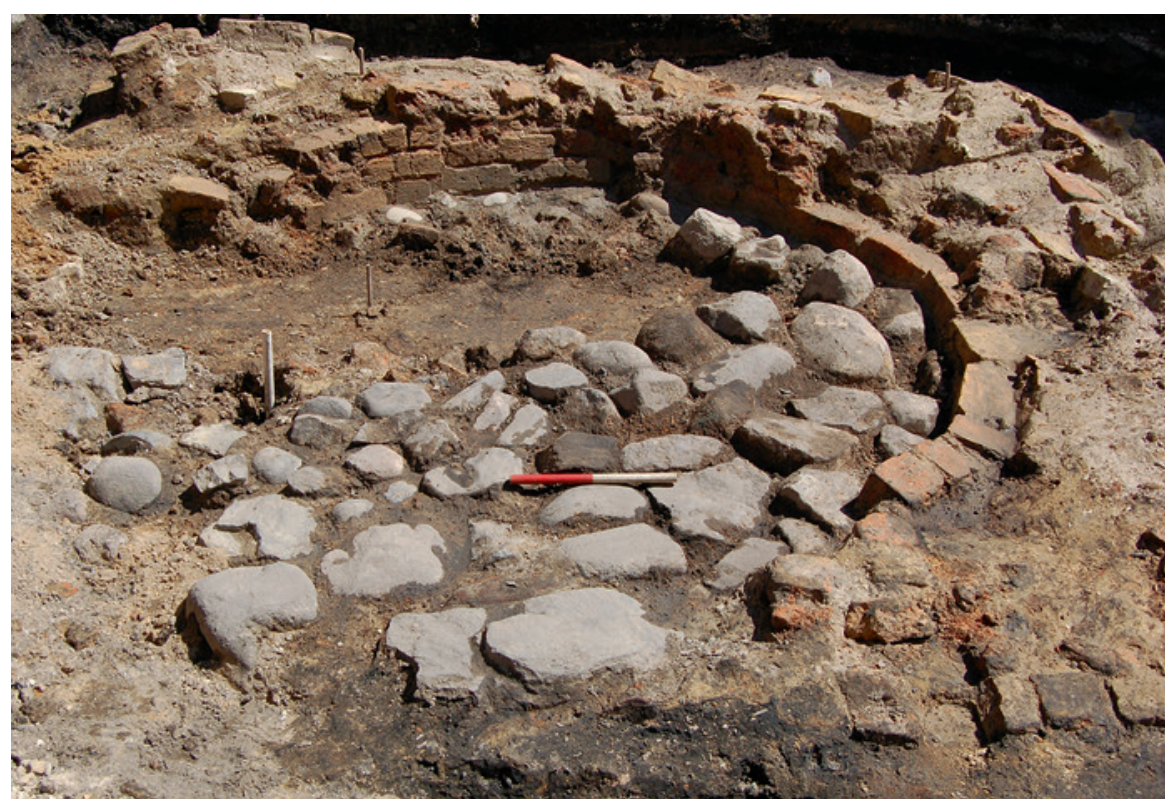

Fig. 14. Den store centrale ildstedskonstruktion i hus A55, ca. 1475-1574, set fra vest.

The large central hearth construction in house A55, c. 1475-1574, seen from the west.

Det er nærliggende at sammenligne hus A221 og A55 med Grønnegade 12 i Ribe, der også bagerst i huset havde en kælder, og over denne var et rum med højt gulv, der fungerede som stue eller herberg. ${ }^{16}$ Dette kan også være tilfældet ved de to huse fra Algade 9, hvis indretning kan sammenlignes med Grønnegadehuset, der var indrettet efter Engqvists nørrejyske planløsning. Selvom den nordlige del af A221 og A55 var bortgravet af kælderen i hus A100 fra 1574, var der forhold, som taler for, at de også har været indrettet efter den nørrejyske planløsning, som den ses ved flere jyske gavlhuse fra 1500-tallet. ${ }^{17}$ Indretningstypen er karakteriset ved få rum, og ved at rummet ud til gaden var en forstue, der blev opvarmet af en kakkelovn. Forstuen har haft handels- og håndværksfunktioner, og det var desuden her, de besøgende blev modtaget. Køkkenildstedet lå i stuen bag forstuen. Dette rum har været det private rum, der foruden køkkenfunktionen har haft opholds- og sovepladser. I overetagen på de bevarede huse med den nørrejyske planløsning har der ofte været mindst et kammer. ${ }^{18} \mathrm{Ud}$ fra bygningskonstruktionen er der intet, der taler imod, at husene A221 og A55 skulle have haft en overetage, ligesom alle kendte bindingsværkshuse fra Aalborg fra 1500-tallet. ${ }^{19}$

Der blev ikke påvist sikre spor efter skillevæggen mellem forstuen og stuen. Det forekommer dog usandsynligt, at huset blot har haft et enkelt meget stort 
rum ud mod gaden. Begge huses ildsteder lå i, hvad der sandsynligvis var det andet rum fra gaden. I hus A55 var ildstedet en meget stor konstruktion muligvis med en skorsten (fig. 14), mens der i A221 var meget sparsomme spor efter ildstedet. Sandsynligvis fordi ildstedet har været opbygget på en bænkkonstruktion, der var blevet fjernet helt ved nedrivningen af huset. Det forreste rum ud til gaden var muligvis indrettet med kakkelovne. Der fandtes nemlig i begge huses nedbrydningslag flere skår af ovnkakler.

Det er tidligere foreslået, at den nørrejyske planløsning sandsynligvis var almindelig i Aalborg allerede fra slutningen af 1300-tallet, og med de to huse A221 og A55 kendes ni senmiddelalderlige huse, hvor der kan argumenteres for denne planløsning. ${ }^{20}$

\section{Opsummering}

I denne artikel fremlægges den del af de mange iagttagelser fra Algade 9, der vedrører bygningerne. Den næsten kontinuerlige bebyggelse gennem næsten 600 år giver et indblik i husenes udvikling på en central parcel i en middelalderkøbstad.

Den ældste bebyggelsesfase fra 900-tallet til slutningen af 1000-årene bestod af krumvægshuse af Trelleborgtypen, med et centralt halrum flankeret af to mindre gavlrum. Trelleborghuset kendes især fra landbebyggelserne, men har altså også indgået i tæt bymæssig bebyggelse. Noget tilsvarende gjorde sig gældende i både Lund og i Viborg. To huse havde vægge af jordgravede stavplanker, mens de tre øvrige huse var bygget i bulkonstruktion af kløvede stammer.

I anden halvdel af 1000-tallet ændredes byggeskikken, idet langvæggene blev rette, og jordgravede stavplanker blev den fremherskende vægkonstruktion. Ændringen sker gradvist over tid, og i anden halvdel af 1000-tallet stod et krumvægget hus side om side med et retvægget. I 1200-tallet blev bulkonstruktionen taget i brug igen. Den største fornyelse var dog introduktionen af bilæggerovnen, som gav mulighed for at have et opvarmet rum uden røggener som ved et åbent ildsted. Bilæggerovnen ser ud til at indgå som en fast del af en egentlig hustype, der var enerådende på grunden gennem hele første halvdel af middelalderen. Der var tale om et beboelseshus med mindst to rum. Indgangen har været til et rum med åbne ildsteder, hvor madlavningen og eventuelle håndværk foregik. Herfra var der adgang til et sove- og opholdsrum opvarmet af bilæggerovnen. Hustypen kan genfindes andre steder i Aalborg og i Viborg.

Omkring midten af 1300-tallet blev Algade 9-grunden omstruktureret, ligesom det var tilfældet flere andre steder i Aalborg. Parcellen henlå nogle få år med blot en staldbygning, inden den igen blev inddraget til beboelse. I 
senmiddelalderen dominerede egentlige bindingsværkshuse. Det er fraværet af jordgravet tømmer, der ses som vidnesbyrd om, at konstruktionen har været fuldt udviklet bindingsværk. I 1400-tallet kan bindingsværkets fodremme være tappet fast i piloteringspæle. Denne konstruktion er undersøgt i Algade 5 og har muligvis også været brugt ved 1400-tallets hus i Algade 9 .

Tidligere er det fremført, at huse i Aalborg har været indrettet efter Engqvists nørrejyske planløsning, og de yngste huse i Algade 9 er ingen undtagelse. Denne planløsning er karakteriseret ved gavlhuse med mindst to beboelsesrum. Indgangen førte til en forstue, hvorfra der var adgang til stuen, der fungerede som køkken og opholdsrum. Selvom der ikke fandtes sikre spor efter skillevægge, tages ildstedernes placering bagtil i husene som indikation på en sådan ruminddeling. Den nørrejyske planløsning er kendt fra bindingsværkshuse over hele Nørrejylland og var i brug i Aalborg fra 1300-tallet og frem til 1600-årene.

Man kan diskutere, hvor geografisk repræsentativ den skitserede udvikling er. Selvom der refereres til enkelte paralleller andre steder i landet, vil dette spørgsmål ikke blive diskuteret yderligere her. Hovedformålet har været at præsentere fundet og derved skabe et grundlag for disse sammenligninger.

\section{Genstandsmaterialet}

Selvom hovedparten af genstandsfundene må karakteriseres som hverdagsting, var der en del fund, der kan betegnes som højstatusgenstande. Det gjaldt således smykker af forskellig type i forbindelse med husene A756, A578, A504 og A452 fra 1000- og 1100-tallet. I Hus A572 blev der fundet et ribben med runer, og ved hus A503 fra begyndelsen af 1100-tallet fandtes halvdelen af et relikviekors i bronze af samme type som Orø-korset. I hus A221 fra 1400-tallet fandtes en spejlramme, og i de yngre huse A344, A221 og A55 blev der fundet drikkeglas og i sidstnævnte tillige rudeglas.

Flere genstande hovedsageligt i form af importeret keramik kunne belyse de internationale kontakter. Den importerede keramik udgjordes i de ældste lag af Østersøkeramik, der blev fundet ved husene A578, A503 og A504. Denne keramik er endnu ikke blevet analyseret, og det kan ikke afvises, at den er hjemligt produceret. Den ældste sikkert importerede keramik udgjordes af Andennekeramik fra 1100- og 1200-tallet, og den blev fundet i A504, A452 og A427. I A428 lå der desuden keramik af den nordfranske Rouen-type. Fra Rhinegnene blev der importeret Pingsdofkeramik, et enkelt skår fandtes i et lag fra 1200-tallet, og dertil stentøj fra A376 og alle yngre huse, dvs. fra 1300-årene og frem. Forskellige norske bjergarter bevidnede kontakterne nordover. I hus A625 fra det tidlige 1000-tal fandtes fragmenter af kværnsten af granatglim- 
merskifer, og i A625, A578, A452 og A428 fra 1000-, 1100- og 1200-årene dukkede forskellige genstande af norsk klæbersten op. Den mest markante norske bjergart var skifer til hvæssesten, hvoraf mere end 120 fragmenter blev fundet $\mathrm{i}$ lagene omkring husene A625, A765, A578, A504, A428, A376 og A350 dateret fra 1000- tallet til 1300-tallet. I hus A625 blev over 30 fragmenter fundet på et afgrænset område i husets nordlige del. Der var tale om to typer skifer: En finkornet type ${ }^{21}$ der hovedsageligt fandtes i lagene dateret frem til 1100-tallet og den grovere Eidsborgtype, der fandtes i lag dateret til hele perioden. Til den mere kuriøse del af importvarer hører auripigment, et gult farvestof, hvis nærmeste naturlige forekomst er Østeuropa, fundet i lagene mellem hus A578 og A504 fra slutningen af 1000-tallet samt muskovitglimmer, brugt blandt andet til lygteglas, fra hus A625, der var dateret til begyndelsen af 1000-tallet.

\section{Katalog}

Kataloget omfatter grundige beskrivelser af samtlige 19 huse, der blev undersøgt på Algade 9-grunden, inklusive det nedrevne bindingsværkshus A100 der stod på grunden i perioden 1574-2007. Der er planer over alle de udgravede huse. På planerne er anlæggene tilhørende husene fremhævet. Planerne er digitaliserede og rentegnede tolkningsniveauer, der hovedsageligt er sammenfaldende med registreringsniveauerne. Planerne viser alle øvrige anlæg fra samme registreringsniveau med en lysegrå streg. Det er angivet i figurteksten, hvis der er tilføjet anlæg fra øvre eller nedre registreringsniveauer til tolkningsniveauet.

\section{Udgravningsmetoden}

Kulturlagene blev gravet stratigrafisk. Registreringen af fladen blev grundlæggende foretaget i 13 tegningsniveauer, der var kunstigt skabte registreringsniveauer, der således ikke repræsenterer afgrænsede tidsfaser. Udgravningsplanerne, der er fremstillet til denne artikel, er de digitaliserede og rentegnede tolkningsniveauer. Denne artikels 11 tolkningsniveauer er hovedsageligt, men ikke nødvendigvis sammenfaldende med registreringsniveauerne. Den primære registrering var i fladen, profilerne blev brugt til hjælp for stratigrafien, i det omfang fladeregistreringen var utilstrækkelig. Hovedprofilerne var en midterbalk centralt gennem hele feltets længderetning samt feltets øst- og vestvendte profiler. Alle de udgravede huse blev således repræsenteret på både plan- og profiltegning.

Ved udgravningen af undersøgelsens niveau 5 , svarende til midten af 1300-tallet, blev det klart, at det hidtidige udgravningstempo ikke var tilstrækkeligt højt til, at udgravningen kunne afsluttes indenfor den fastsatte 
tidsramme. For at undgå maskinafgravning blev det derfor besluttet at øge udgravningstempoet ved udstrakt brug af almindelig håndskovl. Generelt bærer registreringen af huse ældre end 1350 desværre præg af at være udgravet på denne måde. Det øgede gravetempo kom til at betyde, at særligt husene dateret til perioden ca. 1225-1350 i høj grad har måttet tolkes i efterbearbejdningsfasen og sammenstykkes af lag i profiltegninger. Der vil derfor i fremlæggelsen være flere løse ender og uafklarede spørgsmål som følge heraf.

Udgravningsfeltet viste sig at ligge heldigt i forhold til husenes orientering og udstrækning. Grundenes afgrænsning havde kun rykket sig $2 \mathrm{~m}$ siden 1100-tallet, og derfor lå flere af husene nærmest helt inden for udgravningsfeltet. For flere af de ældre huses vedkommende lå op mod to tredjedel af deres udstrækning inden for udgravningsfeltet. De yngste huse fra begyndelsen af 1400 -tallet og frem lå i hele deres udstrækning inden for feltet. Her var den nordlige del af feltet dog forstyrret af en yngre kælder, hvorfor deres forbindelse til gaden mangler. Det var dog alligevel muligt at undersøge store dele af gulvarealet for hovedparten af husenes vedkommende og derved påvise deres indretning og planløsning.

Bevaringsforholdene i de $4 \mathrm{~m}$ tykke kulturlag var meget gode. Der var bevaret træ og andet organisk materiale i næsten alle niveauer. Den gode bevaringsgrad for organisk materiale gjorde, at det var muligt at indsamle prøver til naturvidenskabelige analyser gennem alle lagene. Der blev udtaget prøver til dendrokronologi af alt egnet tømmer. Makrofossilprøver blev hovedsageligt udtaget som søjleprøver fra udgravningens profiler og som floteringsprøver. Det blev tilstræbt, at alle husene var repræsenteret i mindst én søjleprøve.

\section{Hus A691, ca. 985-1010}

I udgravningssituationen herskede der stor tvivl om tolkningen af hus A691, der således i store træk er en efterrationalisering. ${ }^{22}$ Dette har medført en inddragelse af spor, der oprindeligt tolkedes som ardspor, foruden tvivlsomme stolpehuller, der oprindeligt var opgivet efter at være blevet snittet. Tolkningen af huset og dets delelementer er således behæftet med en betydelig usikkerhed (fig. 15).

Hus A691 var, bortset fra grubehusene, udgravningens ældste. Det registreredes i undergrundsniveau og havde modsat alle de yngre huse intet regulært tømmer bevaret. Det blev således kun erkendt ved nedgravninger. Kun et udsnit med husets vestlige langside og den nordlige gavl lå inden for feltet. Det kunne dog fastslås, at huset var orienteret nogenlunde nord-syd med en lille afvigelse mod nordøst-sydvest. Huset var mere end 2,9 m bredt, mens længden var mere end 14,5 m. Den vestlige langside erkendtes som en let krumt væggrøft, der generelt var ganske smal, kun op til $10 \mathrm{~cm}$ bred. Den nordlige del var dog op til $48 \mathrm{~cm}$ bred, hvilket sikkert skyldtes, at denne del var anlagt oven på ældre, opfyldte nedgravninger. Det samme gjaldt den nordlige, øjensynlige rette gavl, der bl.a. tydeligt skar et grubehus. Væggrøften havde en dybde på kun 5-10 cm i det smalle og sydlige forløb i undergrundssandet. I den nordlige del, hvor den nåede op på $45 \mathrm{~cm}$ i dybden, blev der 


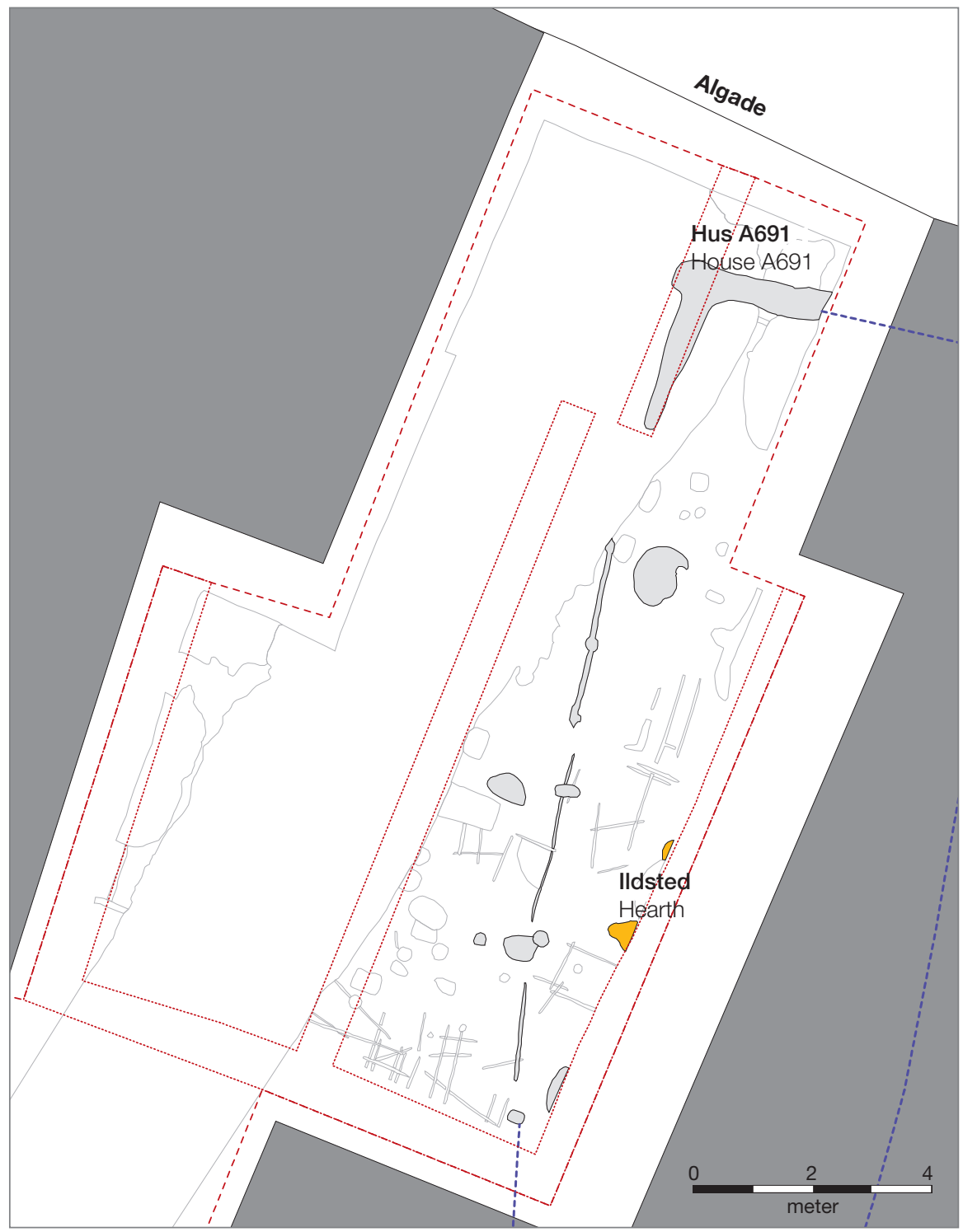

Fig. 15. Plan over hus A691, ca. 985-1010. Planen viser registreringsniveau 12. Husets mulige omrids uden for feltet er stiplet ind. Anlæg tilhørende huset er gråt, og ildsteder er orange. Øvrige anlæg er vist med lysegrå streg. Feltgrænsen og balkene er stiplet med rødt, og de nuværende nabohuse er mørkegrå.

Plan of house A691, c. 985-1010, showing recording level 12. The possible outline of the house outside the excavation trench is marked with a broken line. Features belonging to the house are grey and hearths are shown in orange. Other features are shown with light-grey lines. The trench limits and baulks are marked with broken red lines and the present neighbouring house is dark grey. 
ikke set spor efter tømmer eller andet vægmateriale. I den smallere del sås et enkelt stykke smuldrende træ, der tolkedes som en plankerest.

Langsidens væggrøft blev stedvist afbrudt af stolpehuller, hvortil der syntes at knytte sig et stolpehul fra en udvendig skråstiver. Også langs den nordlige del af langsiden, hvor ingen stolpehuller blev erkendt, synes sådanne at optræde på udgravningsfotografier. Vægstolperne med skråstivere fordelte sig med indbyrdes afstande på 2,5-2,9 m og mindede derved om væggene i de yngre, krumvæggede huse.

Indvendigt i huset var to stolpehuller, der antydede en tredeling med et stort, centralt rum, der flankeredes af et mindre rum i hver gavlende. Det nordlige rum har optaget ca. 4,9 m af husets længde, mens det sydlige gavlrum ikke kunne måles. I det centrale rum var der rester af et tyndt, varmepåvirket lerlag, der formodes at stamme fra et ildsted.

Hus A691 tolkes som stedets ældste regulære beboelseshus. Det eneste genstandsfund, der henførtes til huset, er et muligt fragment af en spydspids af jern.

Dateringen af huset beror alene på de stratigrafiske forhold, hvilket giver en levetid, der ligger inden for perioden ca. 875-1010. Da der sandsynligvis er tale om det første i den række af krumvæggede langhuse, der optræder gennem 1000-tallet, skal hus A691 sandsynligvis dateres til den yngre del af perioden. Det vil sige i slutningen af 900 -tallet eller tiden omkring 1000, svarende til ca. 985-1010.

\section{Hus A625, ca. 1010-1030}

Hus A625 blev erkendt i den østlige del af feltet, hvor et udsnit med den vestlige langside og måske den nordlige gavl kunne registreres (fig. 16). I nordlig forlængelse af hus A625 registreredes hus A756. Forholdet mellem de to huse er uklar. I udgravningssituationen blev de betragtet som enten to huse i forlængelse af hinanden eller reelt som del af samme bygning. I efterbearbejdningen blev den mulighed dog åbenbar, at hus A756 er et yngre hus, der overlapper den nordlige del af hus A625. Nedenstående beskrivelse er givet med udgangspunkt i den oprindelige fortolkning af huset. Huset har været mere end $10 \mathrm{~m}$ langt og havde tydeligvis gået til grunde ved en brand.

Den vestlige ydervæg i hus A625 udgjordes af en række stolpehuller, der antydede et let krumt forløb (fig. 8). Stolpehullerne havde indbyrdes afstande på 1,84-2,28 m. Mellem to af stolpehullerne var bevaret et forkullet tømmerstykke, der antydede en væg med en form for bulkonstruktion. Ved to af vægstolpehullerne var der bevaret $75 \mathrm{og} 84 \mathrm{~cm}$ lange rester af udvendige skråstivere begge af eg. Den ene var en krumvokset og kløvet stamme eller gren med en diameter på 16-18 cm. Den anden havde et ret forløb og en diameter på 16-20 cm. På dennes lodrette og modstående flader var bark og splintved hugget bort, og de nedre ender var ret afskåret. De stod $80-100 \mathrm{~cm}$ fra deres tilhørende vægstolpe og begge med en vinkel på 62 grader. Det betyder for den rette skråstiver, at denne må have mødt vægstolpen i en højde på ca. $188 \mathrm{~cm}$, hvilket giver en antydning af væggens højde.

Den nordlige gavl blev erkendt ved et vandretliggende, forkullet tømmerstykke. I forlængelse af dette stod desuden to stolper, der begge var tildannet til en nærmest fuldkantet form. Tværsnittene målte 7x18 og 8x15 cm. Den ene kunne yderligere beskrives som en kløvet stamme, der kun var lettere tilhugget med delvist bevaret bark. Ved den alternative tolkning med hus A756 som en yngre bygning, synes hus A625's nordgavl at skulle findes ca. 3,3 m længere mod nord.

I det indre af hus A625 blev der erkendt 24 mindre pæle med en diameter på op til $10 \mathrm{~cm}$. En enkelt var dog større og $16 \mathrm{~cm}$ i diameter. Denne stod ca. $85 \mathrm{~cm}$ inden for vestvæggen og har måske haft en tagbærende funktion. Omtrent $190 \mathrm{~cm}$ østligere sås et stolpehul, 


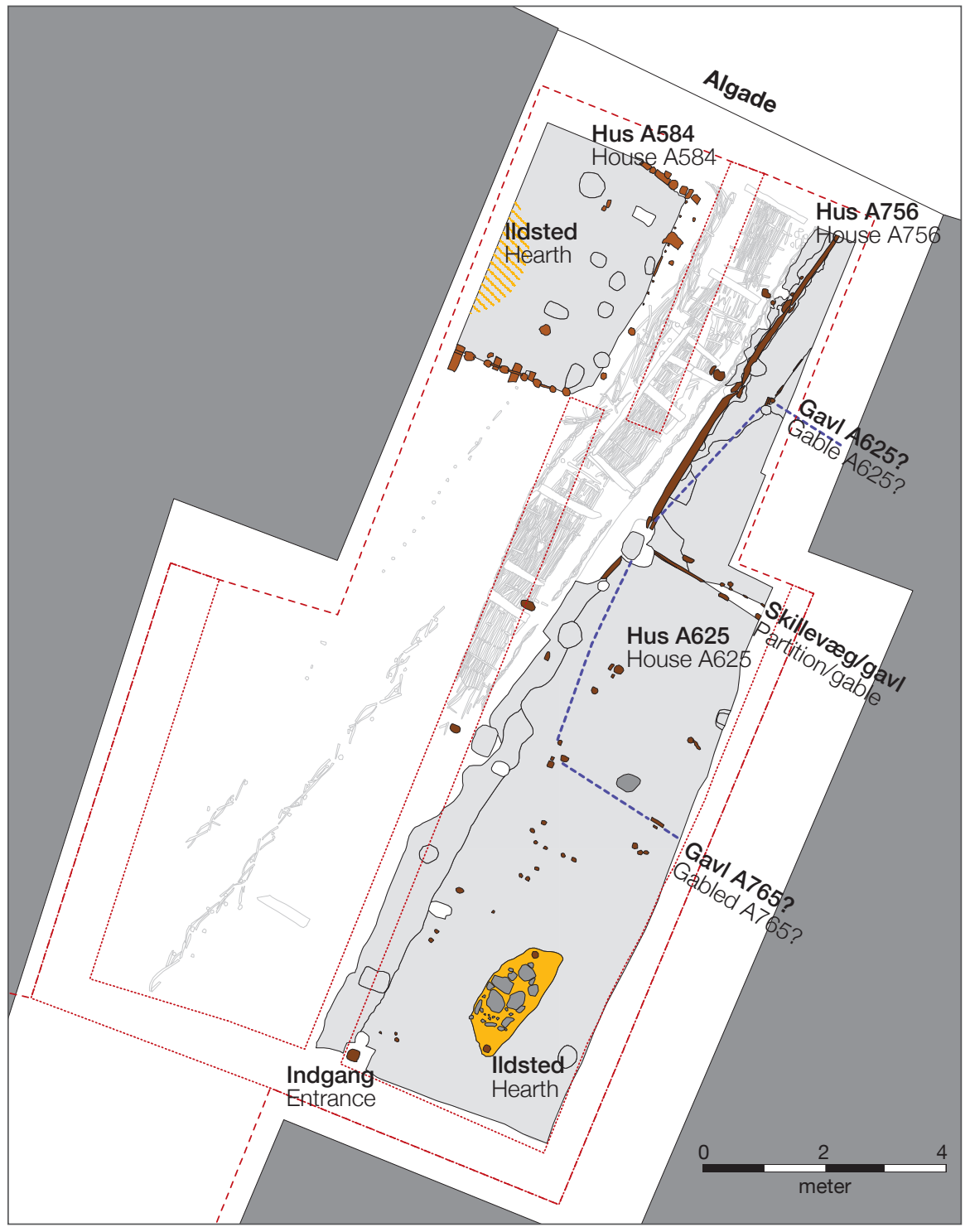

Fig. 16. Plan over hus A625, ca. 1010-1030, hus A756, ca. 1030-1050 og hus A584, ca. 1025-1050. Planen viser registreringsniveau 11, men anlæg fra niveau 10. De alternative tolkninger af hus A625 og hus A756 er stiplet ind. Tømmer, der var bevaret, er brunt, og sten er mørkegrå.

Plan of house A625, c. 1010-1030, house A756, c. 1030-1050, and house A584, c. 1025-1050, showing recording level 11, but structures and features from level 10. The alternative interpretations of houses A625 and A756 are shown with broken lines. The preserved timber is brown and stones are dark grey. 
som angiver en mulig pendant. De øvrige småpæle må have haft andre funktioner i husets indre. Alle pæle var sortbrændte. Centralt i huset lå desuden en omtrent hovedstor sten.

Sydligt i huset sås en relativ kraftig stolpe med et cirkulært tværsnit på $18 \mathrm{~cm}$ i diameter. Også denne var sortbrændt som husets øvrige tømmer. Stolpen stod umiddelbart inden for ydervæggen, og måske var der tale om en dørstolpe. Det efterfølgende hus syntes netop at have en døråbning på dette sted.

I husets sydlige del var der et ildsted, der erkendtes ved en belægning af 12 flade sten med op til hovedstore størrelser. Omkring stenene sås et tyndt lag af gulligt, varmepåvirket sand. Alle stenene var ligeledes tydeligt varmepåvirkede. Belægningen havde en nærmest rektangulær udstrækning, der målte ca. $75 \times 130 \mathrm{~cm}$ med længderetningen orienteret som huset. Den største sten i belægningen var et fragment af en kværnsten af granatglimmerskifer. Ved både den sydlige og den nordlige ende af stenbelægningen stod en forkullet pæl med en diameter på 8-10 cm. De to pæle må have været til grydeophængning, stegning eller lignende over ildstedet.

I huset var der dannet et op til $8 \mathrm{~cm}$ tykt lag af tynde smudsaflejringer, der øverst afsluttedes af et askelag fra husets formodede brand. I aflejringerne blev der fundet keramik, klæbersten, granatglimmerskifer, 30 fragmenter af skifer til hvæssesten, knive, klinknagler, en nøgle, en tenvægt, muskovitglimmer, jernsøm, støberester af bly og sintret ler. Ildstedet angiveer, at der er tale om et beboelseshus.

Hus A625 var efterfølger til hus A691 og efterfulgtes selv af hus A578 og måske også af hus A756. Huset synes at være opført i begyndelsen af 1000-tallet eller senest i 1020'erne. Husets brand må være sket senest ved midten af 1000-tallet, hvorefter det blev opgivet. Dateringen baseres især på tre møntfund, hvoraf én ${ }^{23}$ kommer fra et samtidigt lag uden for huset, mens de andre to ${ }^{24} \mathrm{er}$ fra overlejrende lag. Desuden skal der medregnes to løsfundne mønter fra 1000-tallets begyndelse. ${ }^{25}$ De synes at stamme fra enten det aktuelle hus eller dettes forgænger, A691. Endelig har en hasselnød fra husets gulv givet en C14-datering til 982-1032, der således kan styrke dateringen. ${ }^{26}$ En datering af huset må i årstal foreslås til ca. 1010-1030.

\section{Hus A756, ca. 1030-1050}

Som ovenfor nævnt blev hus A756 og hus A625 opfattet som to huse i forlængelse af hinanden eller som dele af samme hus (fig. 16). Dette var den oprindelige tolkning i udgravningssituationen. Endelig er der den mulighed, at hus A756 er lidt yngre end og delvist overlapper hus A625. Denne sidste tolkning stammer fra efterbearbejdningen, og nedenfor vil der kun i begrænset omfang blive refereret hertil. Hus A625 var tydeligvis brændt ned, hvilket der til gengæld ikke sås spor efter i tømmeret fra hus A756. Hus A756 må derfor mest sandsynligt opfattes som en selvstændig bygning, der enten lå med gavlen helt op mod hus A625 eller måske mere sandsynligt som et lidt yngre hus. I sidstnævnte tilfælde skal husets sydgavl findes ca. 4 m sydligere end ved førstnævnte scenarie. I den længste udgave har huset været mere end 10 m langt. Nedenstående beskrivelse tager dog sit udgangspunkt i den oprindelige opfattelse, at hus A756 lå i forlængelse af hus A625.

Husets vestlige ydervæg kunne registreres over en længde på ca. 5,90 m (fig. 6). Den var velbevaret med adskillige tømmerdele intakt. Væggen havde et svagt krumt forløb. Konstruktionen var simpel bulkonstruktion med vandretliggende fyldtømmer. Det bærende element udgjordes af dobbeltstolper, der hver bestod af to tætstående stolper med en indbyrdes afstand på 2-4 cm. Der blev registreret tre dobbeltstolper, hvoraf den sydligste måske var husets sydvestlige hjørne. Afstanden mellem væggens dobbeltstolper var uens med henholdsvis 2,44 m,1,36 m og en længde på mere end 1,35 m. Hvis huset har overlappet hus A625, må den sydligste del af væggen have haft ca. 4,15 m langt fyldtømmer. Væggen ville i dette tilfælde have et tydeligt krumt forløb. 
Stolperne var enten af mindre kløvede stammer med kun lettere tilhugget overflade eller af mere regulære, fuldkantede planker med rektangulært tværsnit. To af dobbeltstolperne havde en korresponderende stolpe ca. $35 \mathrm{~cm}$ vest for væggen og dermed uden for huset. Begge disse stolper skrånede svagt ind mod huset og må derfor tolkes som udvendige skråstivere. Med en vinkel på ca. 80 grader må skråstiverne have mødt væggen i en højde på ca. $2 \mathrm{~m}$, hvilket måske angav væggens højde. Ved begge skråstivere var der nedrammet to kileformede træstykker til støtte eller stabilisering af disse. En lignende kile sås desuden ved den ene af dobbeltstolperne.

Fyldtømmeret bestod af kløvede småstammer, der var anbragt med den plane side vendt indad. Ydersiden var kun lettere tilhugget med bevaret halvrund profil (fig. 7). Enderne var skråt tilhugget og indstukket i dobbeltstolpernes mellemrum. I det nordlige af væggens fag var fyldtømmeret bevaret i to skifter, mens der i de øvrige kun var et enkelt. Under fyldtømmeret i de to nordligste fag var der anbragt mindre træstykker, der måske skulle stabilisere fyldtømmerets leje og hæve det fra det fugtige underlag. I det sydlige fag havde fyldtømmeret en længde på 2,6 m, mens det i det følgende fag var 1, $58 \mathrm{~m}$ langt. Det nordligste fag afsluttedes uden for feltet. Det har dog været mere end 1,42 m langt.

For væggens vedkommende syntes der i alle tilfælde at være tale om tømmer fra ret tynde stammer med en diameter på op til 20-25 cm. En vedprøve af det nordlige fags nederste fyldtømmer kunne bestemmes til at være af el, hvilket må antages også at gælde de øvrige tømmerdele. ${ }^{27}$ En af vægstolpernes øvre ender havde tydelige hugspor efter økse, hvilket viser, at stolperne ved husets nedrivning blev hugget over i jordniveau og ikke hverken gravet eller hevet op af jorden.

Husets formodede sydgavl udgjordes af en enkelt stolpe og fem mindre pæle. Den har tilsyneladende ikke været i bulkonstruktionen, som der sås ved vestvæggen, men måske har der i stedet været tale om en fletværkskonstruktion på de mindre pæle. Hvis huset har overlappet hus A625, skal sydgavlen og husets sydvestlige hjørne i stedet findes ved to små stolper omtrent $4 \mathrm{~m}$ sydligere. Øst for disse stod desuden en stolpe med udpræget plankeform, som sammen med en mindre stolpe kan have udgjort en dobbeltstolpe i sydgavlen.

Langs indersiden af hele vestvæggen lå en $10 \mathrm{~cm}$ tyk bræmme af opgravet undergrundssand, der strakte sig $60 \mathrm{~cm}$ ind i rummet. Her afgrænsedes den af en vandretliggende og kantrejst, tynd planke og en mindre pæl eller stolpe. Sandet lå således som fyld i en opbygget forhøjning, der måske skal opfattes som en vægbænk. Inden for vægbænken lå lag af henholdsvis lyst silt og organisk affald, der begge må tilhøre husets gulv. Under disse lag lå desuden et organisk lag, der måske skal henføres til huset. Alternativt kan laget snarere opfattes som umiddelbart ældre end huset. Det er særligt fra dette lag, nedennævnte fund stammer.

Til huset blev henført to pilespidser af jern, klinknagler, jernsøm, hvæssesten, skifer til hvæssesten samt et formodet beslag af ben. Hvis tolkningen som vægbænk er korrekt, må der være tale om et hus til beboelse. På grund af fundenes tvivlsomme forbindelse til huset, angiver de snarere tiden for husets opførelse eller tiden, der ligger umiddelbart før.

Hus A756 var yngre end hus A691 og ældre end hus A578. En C14-datering fra husets velbevarede vestvæg har givet dateringen 1023-1185, der således taler for en opførelse, der tidligst ligger i århundredets anden fjerdedel. ${ }^{28}$ Den dendrokronologiske datering fra husets tvivlsomme sydgavl har givet et fældningstidspunkt, der ligger efter 1026. Dateringen af det overlejrende hus A578 tyder på en nedrivning af hus A756 senest ved midten af 1000-tallet. En datering af huset må således foreslås til ca. 1030-1050.

\section{Hus A584, ca. 1025-1050}

Hus A584 registreredes i den nordlige del af feltet, hvor det med en orientering nogenlunde øst-vest har ligget vinkelret på de samtidige eller lidt ældre huse A625 og A756 (fig. 16). 
Den undersøgte del af huset må have udgjort de østlige ca. 2,5 m med den østlige gavl. Ved gavlen var bredden ca. $4 \mathrm{~m}$, hvorfra bredden tiltog i vestlig retning. Husets langsider har derved formentlig haft et krumt forløb.

Den sydlige væg kunne registreres over en længde på ca. $2 \mathrm{~m}$. Det drejede sig om en form for stavværkskonstruktion, hvor der veksledes mellem regulære stavplanker og stolper med cirkulært tværsnit. Stolperne stod med skiftende afstande på 10-22 cm, hvorimellem de lodrette stave var indsat. Stavene var fastholdt i stolpernes ca. $2 \mathrm{~cm}$ dybe notriller. Stolperne var af mindre træstammer med diameter på 10-18 cm. De havde endnu fastsiddende barkrester. Stavene var af fuldkantet egetømmer med en tykkelse på op til $4 \mathrm{~cm}$. Tilvirkningsgraden var således markant højere end for stolpernes vedkommende. Den længste stav var bevaret i en længde på $18 \mathrm{~cm}$.

Stavene var nederst anbragt på et kort tømmerstykke, der vendte på tværs af væggens længderetning. Det drejede sig om kløvede småstammer, der var lagt på den plane side. I oversiden var der hugget en rille eller fure på tværs, hvori plankens nedre ende var anbragt og derved fikseret. Hele væggens konstruktion var nedgravet i en ca. $25 \mathrm{~cm}$ dyb væggrøft.

Den nordlige væg registreredes over en længde på $70 \mathrm{~cm}$ og havde en ringere bevaringsgrad end den sydlige. Stavene manglede således, og kun det underliggende tømmer kunne registreres. Det var orienteret i væggens længderetning.

Husets østlige gavl var ikke konstrueret som stavværket i langsiderne. Til gavlen kunne med en vis usikkerhed henføres et 2,10 m langt forløb af vidjefletværk på tynde pæle. En anelse uden for dette stod en række af stolper, der mere sandsynligt har indgået i gavlen. De største af disse havde en diameter på $10 \mathrm{~cm}$ og var som langsidernes stolper af stammer uden videre tilvirkning.

Indvendig i huset var et antal stolpehuller og bevarede stolper, der formentlig særligt stammede fra yngre konstruktioner. Et par af de bevarede stolper blev dog med en vis usikkerhed henført til husets tagbærende konstruktion. Det drejede sig først og fremmest om en stolpe, der stod $75 \mathrm{~cm}$ inden for sydvæggen og $110 \mathrm{~cm}$ fra østgavlen. Stolpen havde et cirkulært tværsnit med en diameter på $18 \mathrm{~cm}$. Inden for den nordlige væg registreredes en stolpe med en helt tilsvarende placering i forhold til ydervæg og østgavl. Den var dog et fuldkantet tømmerstykke med tværsnittet $12 \times 5 \mathrm{~cm}$.

I feltets vestlige profil registreredes et lag af varmepåvirket, grågult, leret silt, der havde en tykkelse på 6-10 cm. I retningen N-S havde laget en udstrækning på mindst $102 \mathrm{~cm}$. Laget repræsenterede formentlig et ildsted i huset, der således har været at finde ca. $2 \mathrm{~m}$ fra den østlige gavl. I ildstedslaget blev der fundet to jernholdige slagger, hvoraf den ene formodentlig var et essefragment. I huset blev desuden fundet en 13,5 cm lang sømlignende jerngenstand. Helt identiske genstande er fundet på Aggersborg, hvor de kaldes for jerntene. ${ }^{29}$

Ildstedet viste, at huset formentlig skal tolkes som enten et beboelseshus med tilknyttet smedehåndværk eller som en bygning alene til håndværk.

Dateringen af huset afhang i første omgang af dendrokronologiske dateringer af to stave fra sydvæggen. De gav fældningstidspunkter til efter henholdsvis 868 og $964 .{ }^{30}$ De meget forskellige resultater tyder på, at stavene var genbrugt tømmer, hvilket også antydes ved deres relative høje tilvirkningsgrad. Således skal der sandsynligvis lægges et betydeligt antal år til terminus post quem dateringen 964 . Tæt omkring husets gavl forløb et fletværkshegn, der gav en tydelig stratigrafisk sammenhæng med en fletværksvej og dennes samtidige huse A625 og A756. Det taler for en næsten samtidighed mellem de tre huse, hvilket giver et opførelsestidspunkt, der mest sandsynligt skal findes i første halvdel af 1000-tallet. Stratigrafisk synes huset at være kun en anelse ældre end hus A578, der menes opført ved midten af 1000-tallet. En sandsynlig datering for A584 må således være den anden fjerdedel af 1000-tallet. 


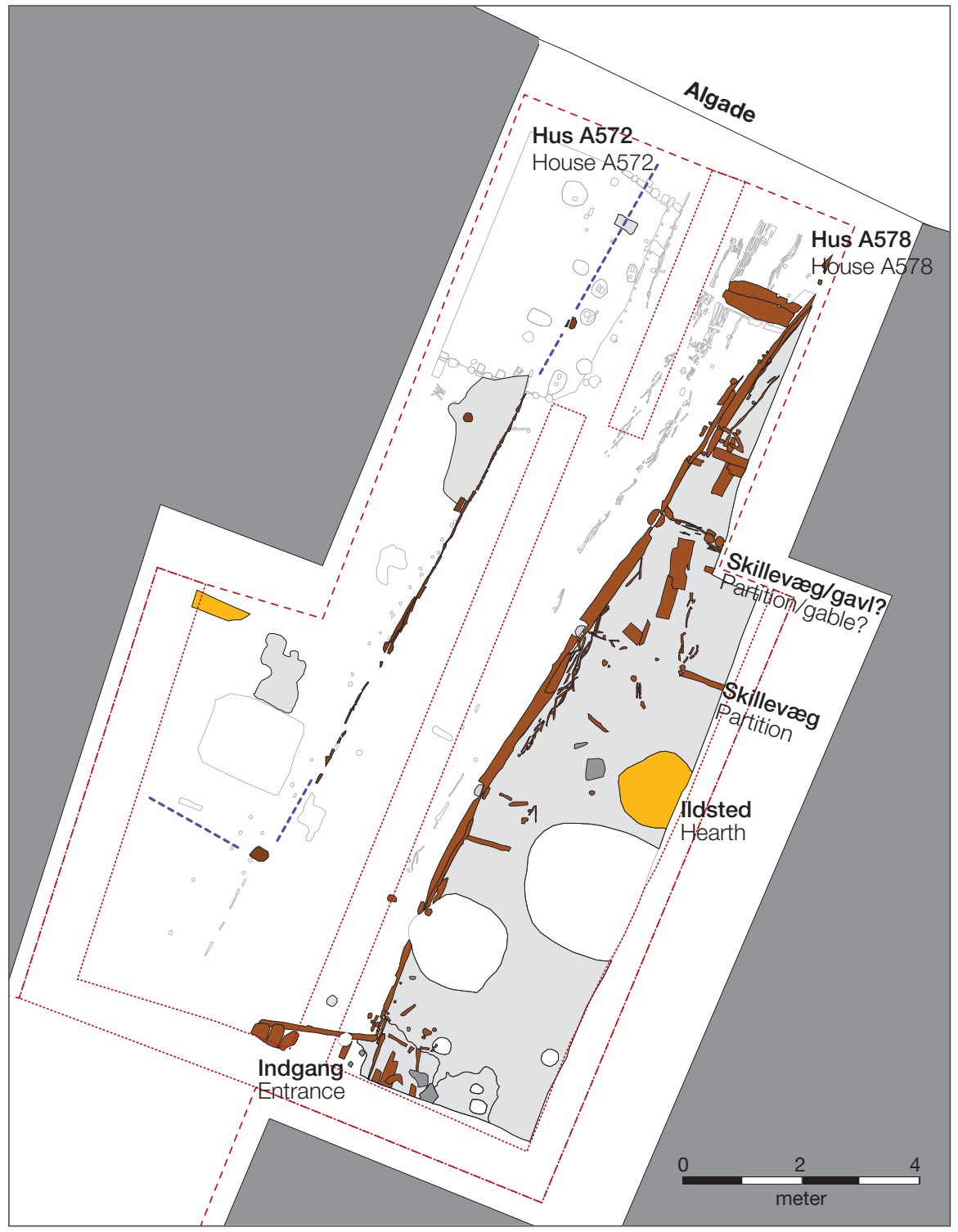

Fig. 17. Plan over hus A572, ca. 1050-1100 og hus A578, ca. 1050-1075. Planen viser registreringsniveau 10.

Plan of house A572, c. 1050-1100, and house A578, c. 1050-1075, at recording level 10. 


\section{Hus A578, ca. 1050-1075}

Hus A578 efterfulgte husene A625 og A756 og er på mange måder en gentagelse af disse - blot med en lidt afvigende placering (fig. 17). Igen synes der således nærmest at være tale om to sammenbyggede dele. Da de to afdelinger af huset i dette tilfælde tydeligt deler samme dobbeltstolpe i ydervæggen, må der her dog retteligt være tale om ét hus.

Huset blev registreret gennem hele feltet over en længde på 15,10 m. Bredden har været mere end $3,35 \mathrm{~m}$.

Den vestlige væg var opført som en slags bulkonstruktion med vandret fyldtømmer mellem lodrette dobbeltstolper (fig. 5). De havde en meget uens karakter, men bestod grundlæggende af to næsten helt tætstående stolper, hvorimellem enderne af det vandrette fyldtømmer var indstukket. Mellemrummet i dobbeltstolperne måltes til 4-6 cm. Den nordligste var særligt velbevaret og bestod af to kløvede stammer, der vendte de plane sider mod hinanden. Overfladerne var afbarket og lettere tilhugget med økse. Den udvendige stolpe stammede fra et træ med en diameter på ca. $28 \mathrm{~cm}$. Den var bevaret i en længde på $70 \mathrm{~cm}$ og havde en nedre ende, der var ret afskåret, men dog hugget skrå fra rundingens side. Ved væggens øvrige dobbeltstolper manglede i et par tilfælde den ene eller begge stolper. De manglende stolper kunne dog registreres som aftryk i jorden, og generelt har de været af samme type som den nordligste - dog med lidt mindre diameter på $16-22 \mathrm{~cm}$. De bevarede stolper havde længder på op til $50 \mathrm{~cm}$.

I et enkelt tilfælde afveg den indre stolpe ved at være en utildannet stamme med en diameter på $12 \mathrm{~cm}$. Også den sydligste dobbeltstolpe adskilte sig markant fra væggens øvrige, men i dette tilfælde ved at udgøres af flere små tætstående stolper med rektangulært tværsnit. Det drejede sig om 10 stk., hvoraf de 7 dannede to tætstående rækker, der vel skulle udgøre den indre og den ydre stolpe. De øvrige 3 små stolper eller pæle syntes at være i konflikt med systemet og var måske tilkommet som senere tilføjelser.

Ved den næstsydligste dobbeltstolpe var en udvendig skråstiver, der stod omtrent $40 \mathrm{~cm}$ fra væggen. Det var en skråstiver af eg med en diameter på ca. $15 \mathrm{~cm}$ og en hældning på ca. 78 grader. Den var bevaret i en længde på $40 \mathrm{~cm}$ og havde en nedre ende, der var lettere tilspidset med øksehug. Hældningen betød, at den må have mødt vægstolpen i en højde på ca. $188 \mathrm{~cm}$. Der blev ikke konstateret skråstivere ved andre af væggens dobbeltstolper.

Væggens vandrette fyldtømmer må generelt beskrives som deformeret og fladmast af jordens tryk. Der var dog tale om mindre og kun lettere tilhuggede stammer, der har haft en diameter på 10-15 cm. Træsorten var løvtræ af en tydeligt mindre bestandig slags end eg. Afstanden mellem dobbeltstolperne og længden på det udfyldende vægtømmer varierede fra 2,0-2,7 m. Nord for den nordligste dobbeltstolpe udgjordes vægtømmeret af to tømmerstykker i forlængelse af hinanden med en samlet længde på 4,2 m. Det nordligste af disse var mere end 3,2 m langt. Langs denne nordlige del var der ingen regulære eller tydelige dobbeltstolper. To steder var vægtømmeret dog fastholdt af mindre pæle. I det ene tilfælde med en pæl på både ud- og indvendig side og i det andet med kun små pæle langs ydersiden.

Ved næsten alle stykker fyldtømmer blev der, foruden det nederste stykke, iagttaget mindre stumper af overlejrende dele. Et enkelt sted kunne der således konstateres rester af $\mathrm{i}$ alt tre skifter. Langs indersiden af en del af væggen var der rester af vidjefletværk på små pæle. Vidjefletværket tolkedes som hørende til vægforløbet, der således har haft et dobbelt forløb med bulkonstruktionen yderst og fletværkskonstruktionen inderst.

Ved den sydligste del af vestvæggen var der rester af en plankebelægning, der foruden et mindre parti inden for væggen også strakte sig udenfor og væk fra huset. Belægningen 
må være beregnet til færdsel, der samtidig antydede, at der har været en døråbning det pågældende sted.

Uden for husets nordlige del og helt op mod væggen lå to kraftige planker, der ligeledes må tilhøre en gangflade. Væggens fyldtømmer syntes dog ikke at tale for døråbning det pågxldende sted.

Som nævnt indledningsvist kan huset nærmest opfattes som to sammenbyggede huse. Adskillelsen skal findes ved vestvæggens nordligste dobbeltstolpe, der samtidig syntes at have været væggens kraftigste. På det helt tilsvarende sted i forgængerhuset A625 blev dette adskilt i to selvstændige huskonstruktioner A625 og A756. På samme måde kan det foreslås, at også den nordlige del af hus A578 skal betragtes som en selvstændig bygning, der godt nok synes at være bygget sammen med den øvrige del.

Fra den kraftige dobbeltstolpe udgik desuden et formodet vægforløb i østlig retning. Det bestod af fingertykke vidjer, i hvis østlige del indgik tre tætstående stolper. To af disse kunne bestemmes som værende henholdsvis af birk og eg. Den tredje var en kløvet stamme, der var anbragt tæet op mod egestolpen, således at disse dannede en dobbeltstolpe af samme type som i vestvæggen. Væggen tolkedes som en tværgående skillevæg i hus A578, men kan altså alternativt tolkes som den egentlige nordgavl i huset, hvortil der knytter sig et tilbygget afsnit mod nord.

Omtrent 2,25 $\mathrm{m}$ syd for den ovennævnte skillevæg eller gavl blev der ligeledes set rester af et tværgående fletværksforløb. Også dette forløb, hvori der desuden indgik et spinkelt, vandretliggende tømmerstykke, blev opfattet som en indre skillevæg. Foruden de to foreslåede skillevægge blev der set andre rester af fletværk, der ikke umiddelbart lod sig forklare som vægspor.

Centralt i husets indre blev der registreret en belægning af nævestore sten, der må stamme fra et åbent ildsted eller en ovn. Stenene overlejredes af et lerlag, der tydeligvis var varmepåvirket, og på hvilket der var dannet et tyndt lag af trækul. Dette overlejredes af endnu et lag af varmepåvirket ler, der enten må være en yngre fase i ildstedet eller nedbrudt ovnmateriale. Det formodede ildsted eller ovn havde i plan en nogenlunde cirkulær form, der målte $1,3 \mathrm{~m}$ i diameter.

I størstedelen af huset var der aflejret et op til $26 \mathrm{~cm}$ tykt affaldslag. Dette bestod hovedsageligt af grønligt, organisk materiale med indhold af bl.a. fækalier, dyrehår fra ko eller gris, fiskeben, æggeskaller, en østersskal og dyreknogler. Det indeholdt desuden et stort genstandsmateriale i form af stumper af tildannet træ, læderstumper, en lædersål, en tekstilrest, en glasperle, en dragtnål af knogle, et tøndeformet vægtlod af bronze, en synål af jern, en tenvægt af bjergart, en tenvægt af knogle, et spænde af jern, en kniv, en jernten, en nøgle, fem klinknagler/-plader, hvæssesten, skifer til hvæssesten, hår, gråbrændt keramik, Østersøkeramik og klæberstensskår. Laget overlejrede det centrale ildsted og kan således repræsentere en ændring i rummets funktion fra almindelig beboelse til stald. I området mellem de to tværgående skillevægge indeholdt laget en del stave og bunddele fra bødkrede trækar, foruden enkelte andre plankestumper. Måske skal trædelene tolkes som en bevidst udlagt flade til færdsel. Ved og i huset blev der desuden fundet skåret læderaffald, en bøjlesaks, en synål af jern, et fragment af en bronzebarre og to klinkplader.

I den sydlige del af huset, umiddelbart inden for plankebelægningen og den formodede døråbning, blev der registreret tynde lag af grågult silt, afsat organisk materiale, klumper af kridt, ler, trækul og enkelte dyreknogler. Skiftet fra det mere rene gødningslag til disse tyndere afsatte lag skete ved den sydligste dobbeltstolpe. Omtrent $70 \mathrm{~cm}$ inden for denne var desuden en lille stolpe, to mindre pæle og et muligt stolpehul. På dette sted må der også foreslås en tværgående skillevæg i huset.

Hus A578 efterfulgte hus A625, der syntes at tilhøre første halvdel af 1000-tallet. I lagene, 
der adskilte de to huse og dermed dannede etableringsniveau for hus A578, fandtes en mønt med dateringen ca. 1035-1055. ${ }^{31}$ Desuden fandtes en anden, der usikkert er dateret til 1037-1105..$^{32}$ På baggrund af disse må hus A578 tidligst være opført i perioden ca. 10371055. I husets gødningsholdige lag blev der fundet to mønter, der henholdsvis skal dateres til 1039-1056 og tiden efter ca. $1050 .{ }^{33}$ Disse to mønter fra selve huset synes altså at bekræfte en datering til midten af 1000-tallet eller kort før. Det samme gælder et løst plankefragment fra samme lag. Dette har givet en dendrokronologisk datering til efter $1028 .{ }^{34}$ De to planker, der må tilhøre en gangflade uden for husets nordlige del, har givet dendrokronologiske dateringer til efter henholdsvis 1055 og $1056 .{ }^{35}$ Plankerne var sekundære i forhold til huset og antydede kun, at huset eksisterede i 1050'erne eller derefter. Da der med stor sandsynlighed er tale om genbrugt træ, bør de måske angive et opførelsestidspunkt, der snarere skal findes omkring 1050 end i 1030'erne.

Fra et overlejrende lag stammer udgravningens ældste sikre danske mønt, nemlig en Svend Estridsen fra omkring 1060. ${ }^{36}$ Fra det efterfølgende hus A504 stammer desuden en dendrokronologisk datering, der viser, at dette hus fra slutningen af 1000-tallet må være opført efter 1064. Hus A578 må således mest sandsynligt have eksisteret i tredje fjerdedel af 1000-tallet.

\section{Hus A572, ca. 1050-1100}

Mod vest på grunden lå huset A572, der var meget ufuldstændigt bevaret (fig. 17). Huset var mere end $14 \mathrm{~m}$ lang og mere end 3,3 m bredt. Det var udgravningens ældste hus med rette langsider og havde været i brug samtidigt med husene A578 og A504.

Husets tag var båret af jordgravede stolper og af væggen. Stolperne stod i væglinjen, og der var fire bevarede stolper og et stolpehul. De tre nordlige stolper var dobbeltstolper. Den sydligste havde cirkulært tværsnit på $22 \mathrm{~cm}$, og den hældede tydeligt mod øst. Det er tvivlsomt, om denne stolpe skal henføres til hus A572. Den synes dog at modsvare den sydlige udstrækning af huset, der ses i den vestlige profil og kan derfor markere husets sydøstlige hjørne. Væggen udgjordes af en række tætstående, lodrette stavplanker, der var 13-25 cm brede. Størsteparten af stavplankerne havde en tykkelse på ca. $2 \mathrm{~cm}$. En mindre del havde et trekantet tværsnit og var således blot spejlkløvede planker uden videre tilvirkning. Stavplankerne stod i en 30-40 cm bred væggrøft.

Huset har fortsat ud af feltet mod nord og vest. Gulvene var af ler. I husets sydlige del var et ildsted, et op til $18 \mathrm{~cm}$ tykt lag ler iblandet en del nævestore sten. Det så ud til at være anbragt i en lav nedgravning. Stenene kunne tyde på, at ildstedet var en ovn. Der var dog ikke spor efter lodrette vidjer, der kunne understøtte dette. Huset tolkes alene på grundlag af ildstedets tilstedeværelse som et beboelseshus. Fundmaterialet bestod af et dyreribben med runer, en pyntenitte af kobber og et fragment af en brændt vævevægt af ler.

Hus A572 var den umiddelbare efterfølger til hus A584, der dateres til anden fjerdedel af 1000-tallet. Derfor blev huset sandsynligvis bygget omkring midten af 1000-tallet. Undersøgelserne af makrofossilerne viste, at der, efter at hus A572 var blevet nedrevet, sandsynligvis var en længere periode uden bebyggelse på stedet. ${ }^{37} \mathrm{Da}$ det efterfølgende hus A503 blev bygget i første halvdel af 1100-tallet, må perioden uden bebyggelse høre til i begyndelsen af 1100-tallet. Huset kan anslås til at have eksisteret ca. 1050-1100.

\section{Hus A504, ca. 1075-1165}

Hus A504 lå i feltets østlige del og havde en længde på mere end $14 \mathrm{~m}$ og en bredde på mere end 4,15 m (fig. 18). Lagene tilhørende huset havde en tykkelse på op til $50 \mathrm{~cm}$, hvilket indikerer, at det har haft en lang levetid. Det har været i brug samtidigt med A572 


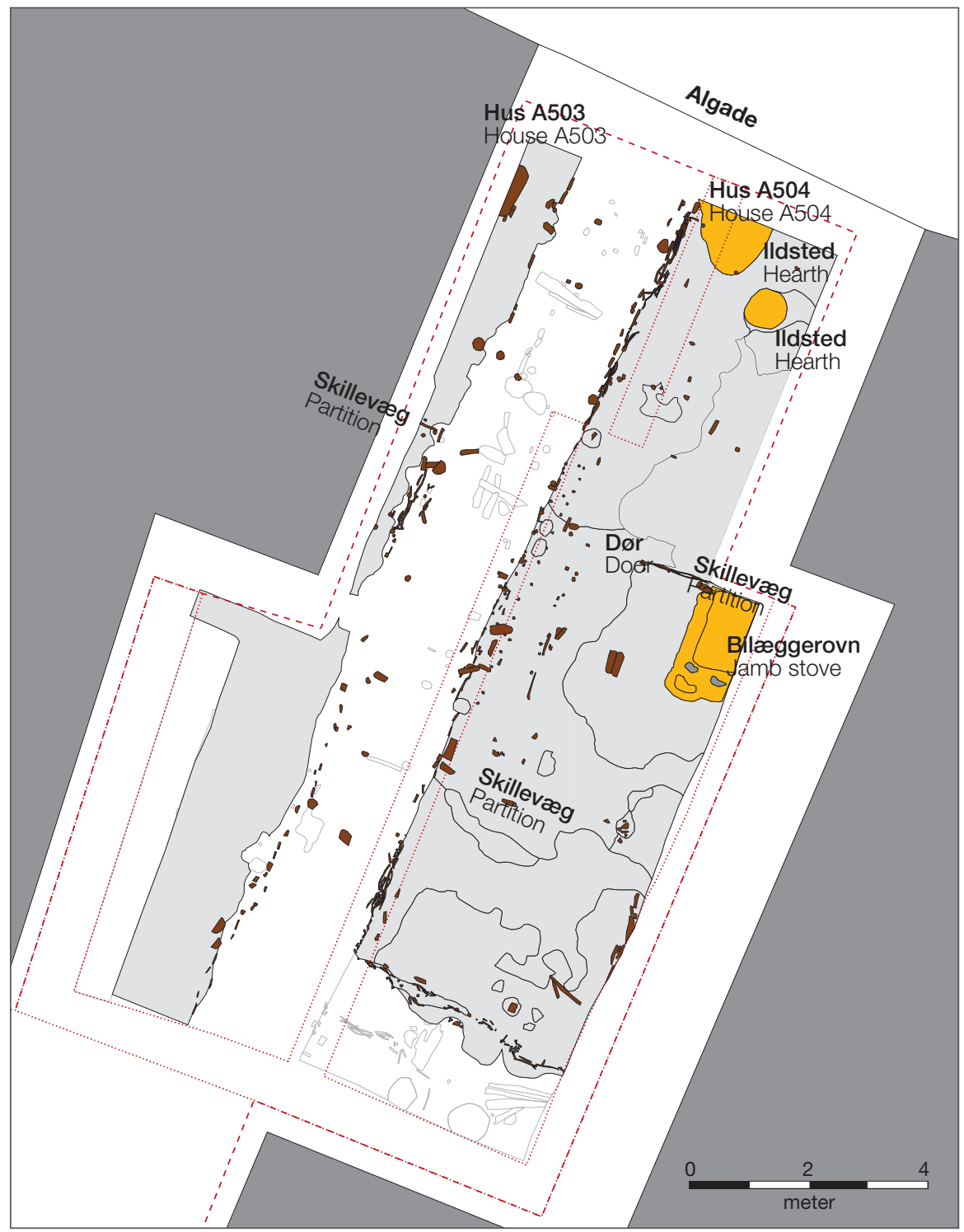

Fig. 18. Plan over hus A504, ca. 1075-1165 og hus A503, ca. 1115-1225. Planen viser registreringsniveau 9.

Plan of house A504, c. 1075-1165, and house A503, c. 1115-1225, at recording level 9. 
og A503. Den vestlige ydervæg bestod af en stor mængde planker, stolper og småpæle, der tilsammen gav et svært tolkeligt indtryk, og det kan ikke afvises, at der muligvis er tale om to huse med samme udstrækning.

Taget var sandsynligvis båret af jordgravede stolper, der stod lidt inden for væglinjen. Fire af stolperne var bevarede, og de var alle fuldkantede og havde et rektangulært tværsnit på $4 \times 10-24 \mathrm{~cm}$. Derudover var der yderligere tre stolpehuller fra yderligere tre stolper. Den vestlige ydervæg bestod af to parallelle forløb. Det ene var af jordgravede stavplanker, 8-24 cm brede og 2-4 cm tykke. På indersiden af stavvæggen var et fletværksforløb, der kan have fungeret som en indre vægbeklædning sammen med stavvæggen. Der var dog tvivl om samtidigheden, og fletværket kan i stedet repræsentere et yngre selvstændigt vægforløb. Væggene i den sydlige del af huset bestod udelukkende af lerklinet fletværk.

Huset var delt i tre rum af to skillevægge. Rummene havde alle husets fulde bredde. Den nordlige skillevæg var af fletværk. I dennes vestlige ende var to stolper, der tolkes som en døråbning med en bredde på $120 \mathrm{~cm}$. Den sydlige skillevæg blev erkendt ved to stolper og forskelle i gulvlagene. Ydervægskonstruktionen i det sydlige rum var desuden også forskellig fra konstruktionen i de to nordlige rum. Huset havde meget tynde lergulve i det nordlige og sydlige rum. I det midterste rum var det ældste gulv et jordgulv. Hen over jordgulvet var et lag af brændt lerklining. Laget stammede sandsynligvis fra en ombygning af rummets ovn, men det har fungeret som gulvbelægning. Det ældste gulv i det midterste rum respekterede begge husets skillevægge, derfor lå husets ruminddeling fast fra opførselstidspunktet.

I det nordlige rum var der spor efter to ildsteder. Det nordlige bestod af et lerlag indeholdende granitskærver. Der var rester efter enkelte vidjer langs kanten, men ellers iagttoges der intet, som kunne tyde på en ovnkappe. Det har derfor sandsynligvis været et åbent ildsted. Ved siden af havde et område i gulvet tydeligvis også fungeret som et ildsted i en periode. I det midterste rum fandtes husets største ildsted (fig. 10). Det var en 197x $103 \mathrm{~cm}$ stor ovn, der havde været nedbrudt og genopbygget to gange. Ovnbunden var opbygget i ler med en indre belægning af nævestore sten. Stenene lå dækket af et hårdt brændt lerlag, som har været ovnens brugsflade. Den viste, at ovnkammeret har været $135 \times 75 \mathrm{~cm}$. Ovnåbningen lå i den nordlige skillevæg, og ovnen var derfor en bilæggerovn med indfyring fra husets nordlige rum. Det midterste rum i hus A504 har derved kunnet opvarmes uden røggener. På ovnens sydside var der i den ældste fase tilføjet en lille halvcirkulær opbygning i ler. Den havde en hvælvet fordybning, der var fyldt med trækul. Funktionen af dette lille ildsted er ukendt, men det kan have været et glødegemme. Da bilæggerovnen overlejrede det ældste gulv i huset, var den tilføjet senere i husets levetid. Den har derfor ikke været en del af husets oprindelige indretning.

Husets ildsteder lå i det nordlige og det midterste rum. Disse rum tolkes derfor som husets beboelsesdele. Tolkningen underbygges af makrofossilundersøgelserne, der viser, at husholdningsaffaldet hovedsageligt fandtes i de to nordlige rum. Funktionen af det sydlige rum var mere uklart, men rummet kan have været anvendt som værksted eller til opbevaring. Der var i alle rum i huset en del frø fra pors, der normalt sammenkædes med ølbrygning, mens der ikke var spor efter malt, og det var derfor muligvis indsamlet til salg eller til brygning, der i så fald foregik et andet sted. ${ }^{38}$ I husets midterste rum fandtes flere skår fra samme kande af importeret Andenne-keramik. Dette vidner sammen med en blå glasperle om mere velstående beboere. Desuden fandtes gråbrændte keramikskår, tre mulige skår af Østersøkeramik, en fibula med mulig forgyldning, en jernnøgle, en mulig sav, diverse søm og beslag i jern, diverse kobberbeslag, rester af lædersko, en spids trægenstand, en tenvægt, to dragtnåle i ben, hvæssesten og råmaterialer til samme.

Hus A504 overlejrede hus A578, der dateredes til midten af 1000-tallet. En mønt fra laget i mellem de to huse er fra ca. $1060,{ }^{39}$ og et tømmerstykke fra husets opførelsestidspunkt 
er dendrokronologisk dateret til efter 1064. Hus A504 blev derfor sandsynligvis bygget i slutningen af 1000-tallet. Yderligere én stolpe blev dendrokronologisk dateret til 1115$1130 .{ }^{40}$ Det kan være på dette tidspunkt, at huset gennemgik en større renovering eller ombygning. Huset blev nedrevet ved opførelsen af hus A452 i 1160'erne. En datering af huset må således foreslås til ca. 1075-1165.

\section{Hus A503, ca. 1115-1225}

Hus A503 lå mod vest i feltet, og hovedparten af huset lå uden for feltet (fig. 18). Bredden af huset har været mere end $3 \mathrm{~m}$. Husets sydgavl lå sandsynligvis uden for feltet, og længden har da været over 16,75 m. Huset har været i brug samtidigt med A504 og A452.

Den tagbærende konstruktion indgik i ydervæggen, hvor der stedvist var mulige tagbærende stolper. Uden for ydervæggen var der otte skråtstillede stolper, der sandsynligvis også har haft en bærende funktion. Stolperne i væggen og skråstiverne stod ikke konsekvent i par, og det var noget uklart, hvordan den tagbærende konstruktion præcist var udformet. Der var 60-80 cm mellem skråstiverne og væggen, og skråstiverne havde en vinkel på 64-70 grader. Det betyder, at skråstiveren har mødt væggen 1,7-1,85 m over jorden, hvilket giver et fingerpeg om væghøjden. Væggen har været af jordgravede stavplanker, og der var brugt kraftigere tømmer i dens nordlige del i forhold til den sydlige. I et kort parti midt i huset var ydervæggen af fletværk, men dette kunne være en reparation.

En skillevæg af vandrette tømmerstokke deler huset i mindst to rum. To tredjedele af husets areal var dog syd for skillevæggen, og det kan derfor ikke afvises, at der har været endnu en skillevæg. Den lettere vægkonstruktion i den sydlige del antyder ligeledes endnu en opdeling. Huset havde lergulv i den nordlige del og jordgulv i den sydlige.

På trods af, at der ikke blev observeret ildsteder i huset, tolkes det som et beboelseshus. I makrofossilprøverne var der smeltet, brændt og forglasset ler, der viste, at huset sandsynligvis har haft et ildsted..$^{41}$ I slippen umiddelbart øst for huset fandtes halvdelen af et relikviekors i bronze.

Hus A503 blev bygget efter hus A572, der dateres til anden halvdel af 1000-tallet. Der var dog en periode uden bebyggelse imellem de to huse, og hus A503 var derfor sandsynligvis opført i begyndelsen af 1100-tallet. Huset blev nedrevet senest ved opførelsen af hus A427 sandsynligvis omkring 1200. I årstal må huset derfor have eksisteret ca. 1115-1225.

\section{Hus A452, ca. 1165-1225}

I feltets østlige del lå hus A452, og hovedparten lå inden for feltet (fig. 19). Huset har været 14,2 m langt og mindst 4,4 m bredt. Den nordlige del blev udgravet hurtigere end resten af huset, nordgavlen blev derfor ikke påvist med sikkerhed. Nordligst i feltet sås dog den vidjebrolagte gade, og derfor har nordgavlen ligget inden for feltet. Huset var i brug samtidigt med A503.

Taget i hus A452 har været båret af ydervæggen og af stolper umiddelbart inden for væggen. Stolperne stod på syldsten. Der var stadig fem sten in situ, og afstanden mellem stolperne var 1,6-1,8 m. Ydervæggen bestod af jordgravede stavplanker med uens bredde. Plankerne var helt tætstillede, og enkelte steder var en indvendig ekstra planke naglet fast, sandsynligvis for at lukke utætheder i væggen. Sydgavlen var også bygget med jordgravede stavplanker, her kunne væggrøften dog ikke registreres. Der var desuden fire planker, der tydeligvis var fra en senere reparation af gavlen.

Huset har som det forrige haft tre rum, alle i husets fulde bredde (fig. 9). Den nordligste skillevæg var som ydervæggen af jordgravede stavplanker. I væggen indgik desuden en- 


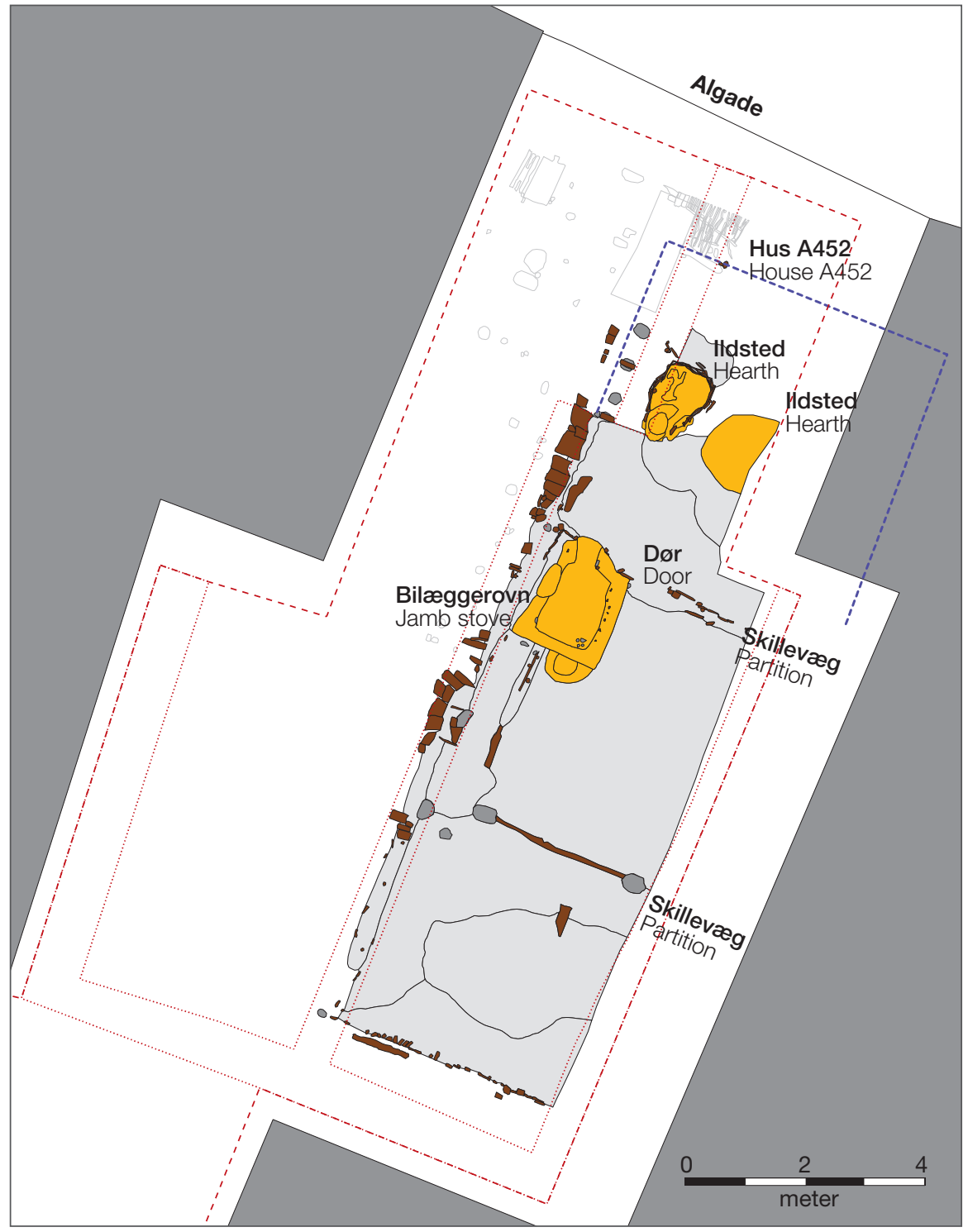

Fig. 19. Plan over hus A452, ca. 1165-1225. Planen viser registreringsniveau 8. Tolkningen af husets nordlige del er stiplet ind.

Plan of house A452, c. 1165-1225, at recording level 8, with interpretation of its northern part marked with a broken line. 
kelte mindre stolper med rektangulært tværsnit. Konstruktionen af den sydlige skillevæg var mere uklar. I fladen sås den som et spor af formuldet og nedbrudt træ sandsynligvis efter et vandret tømmerstykke. Ved hver ende af træsporet var en hovedstor kampesten. I profilen sås derimod en væggrøft som ved husets øvrige vægge. Træsporet kan opfattes som en fodrem, men væggrøften peger på en stavplankevæg. Muligvis afløser den ene vægkonstruktion den anden. Gulvene i alle husets tre rum var af tørv udskåret i rektangulære stykker og lagt med græssiden nedad. Det ældste tørvegulv så ud til at være udlagt, før huset blev opført. I det midterste rum blev tørvegulvet fornyet på et tidspunkt i husets levetid.

Hus A452 havde i det nordlige rum to ildsteder, hvor det ene afløste det andet. Det ældste lå nogenlunde centralt i rummet og bestod blot af et varmepåvirket lerlag med en tykkelse på 6-8 cm. Ildstedet har været et åbent ildsted. Det andet ildsted var en $140 \times 98 \mathrm{~cm}$ stor spidsoval leropbygning, der var kantet af fletværk. Fletværket havde en åbning mod syd, der i begge sider var flankeret af lodrette planker, som var forkullede i toppen. Varmepåvirkningen af brugsfladen var mest markant i den centrale del og i særdeleshed i området mellem de to planker. Der var ikke spor efter ovnkappe, og det omgivende fletværk synes at være en ramme, hvori lerbunden var opbygget. De øvrige ovne havde desuden et skelet af lodrette vidjer uden vandret fletværk. Ildstedet tolkes derfor som et åbent ildsted. Varmepåvirkningen af brugsfladen antyder en mulig forbindelse til et håndværk.

Som ved det foregående hus var hovedildstedet en ovn i det midterste rum (fig. 11). Den var $198 \times 168 \mathrm{~cm}$ og lå ved den vestlige ydervæg. Indfyringen har også her været i det nordlige rum, således det midterste rum var røgfrit. Bunden var opbygget i ler med et indre lag af granitskærver, som må være fremstillet i huset, da flere af smudslagene indeholdt mindre stumper af samme type skærver. Ovnbunden var blevet fornyet to gange. Brugsfladen i ovnen var ca. 130 x98 cm. Der var spor efter lodrette vidjer fra skelettet til ovnkappen. Ovnens rektangulære form tyder på en nærmest tøndehvælvet ovnkappe. På sydsiden af ovnen var et lille halvcirkulær anlæg med en hvælvet fordybning som ved ovnen i hus A504. Anlægget kan have fungeret som et glødegemme. Det var i to faser og var fornyet samtidigt med gulvet i det midterste rum. Syd for ovnen var der opbygget en mulig vægbænk af tørv. Tøvelaget var ind mod rummet kantet med planker. To plankestykker var bevarede i form af formuldede spor. Plankerne var fastholdt af mindre pæle. Vægbænken var 270x70 cm.

Husets beboelsesdel har sandsynligvis været de to nordlige rum. I disse rum befandt ildstederne sig, og makrofossilundersøgelserne viste, at her lå hovedparten af husholdningsaffaldet. Makrofossilerne viste desuden, at bilæggerovnen sandsynligvis også har været brugt til madlavning. ${ }^{42}$ Køkkenet må derfor have været i det nordlige rum. Det yngre ildsted i dette rum peger desuden på, at der også foregik håndværksaktiviteter i dette rum. Funktionen af husets sydlige rum var som ved det forrige hus uklart, men det var i dette rum, at der var flest rester fra tilhugningen af skærver til ovnen. Rummet kan derfor have haft en værkstedsfunktion. Som ved hus A504 var der også i hus A452 store mængder frø fra pors.

Et vægtlod af bly, importeret Andenne-keramik og importeret klæbersten peger på, at husets beboere har haft tilknytning til et internationalt handelsmiljø. Skår efter udgravningens ældste hjemlige glaserede kander fandtes desuden i husets lag. De øvrige genstandsfund var en fiskekrog, to fingerringe, en celleemaljefibel, ${ }^{43}$ jernknive, en benkam, en tenvægt af ben, et bronzebeslag og flere ubestemmelige jerngenstande.

Hus A452 blev ifølge dendrokronologiske dateringer opført i 1160'erne. De tre daterede prøver var fra ydervæggen mod vest. De indeholdt alle tre splint og blev dateret til 11551170, 1154-1167 og 1157-1170. ${ }^{44}$ Den meget enslydende datering af prøverne tyder på, at de ikke stammer fra genbrugstømmer. Huset blev nedrevet ved opførslen af hus A428 i begyndelsen af 1200-tallet. At hus A452 har været i brug ind i 1200-tallet underbygges desuden ved, at der fandtes skår af hjemlige glaserede kander i huset. huset har sandsynligvis eksisteret i perioden ca. 1165-1225. 


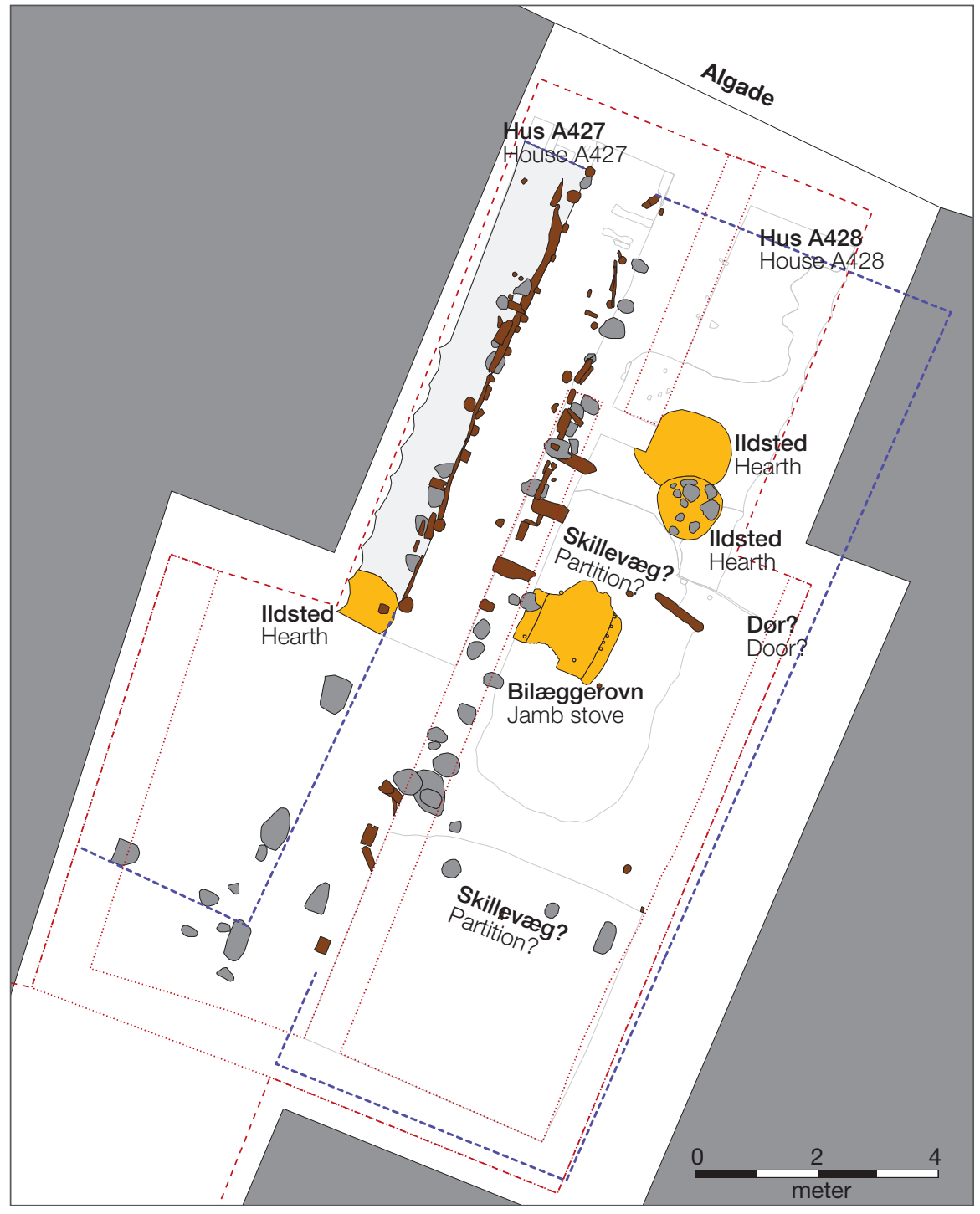

Fig. 20. Plan over hus A427, ca. 1225-1260 og hus A428, ca. 1225-1300. Planen viser registreringsniveau 7 med enkelte anlæg fra niveau 6. Det mulige omrids af husene er stiplet ind.

Plan of house A427, c. 1225-1260, and house A428, c. 1225-1300, at recording level 7 and showing a few features from level 6 . The possible outlines of the buildings are shown with broken lines. 


\section{Hus A427, ca. 1225-1260}

Hus 427 lå på den vestlige del af grunden, og en stor del af huset lå uden for feltet (fig. 20). Huset blev udgravet i forceret tempo, hvilket vanskeliggjorde tolkningen og forståelsen af huset. Det var omkring $14 \mathrm{~m}$ langt og mere end $3 \mathrm{~m}$ bredt, dog er tolkningen af hele husets sydlige halvdel behæftet med stor usikkerhed. Huset har fungeret samtidigt med hus A428.

Husets tagbærende stolper stod i ydervæggen, og der var syv stolper bevaret i den nordlige ende af huset. Stolperne stod med en indbyrdes afstand på 1 til 1,8 m. De var ikke alle fuldstændigt tilhuggede, og flere af dem havde således runde tværsnit (fig. 3). Husets nordgavl blev ikke sikkert påvist, men rester af den plankebelagte gade angav nordgavlens omtrentlige udstrækning. Væggen tolkes som en form for bulkonstruktion. De nederste vandrette planker lå på få spredte syldsten. Enkelte pæle har støttet væggens nederste planke mod udskridning. Der blev ikke registreret vægkonstruktioner i husets sydlige halvdel. Sydgavlens afgrænsning blev fastslået ud fra gulvenes udstrækning i profilen og ud fra enkelte spredte syldsten. Husets gulve var hovedsageligt af ler.

Midt i huset lå et stort ildsted, som bestod af en op til $80 \mathrm{~cm}$ tyk lerbund, der tydeligt fremstod i to faser. Den massive lerkonstruktion og beliggenheden ud til ydervæggen mindede om bilæggerovnene i husene A504 og A452.

Trods den mangelfulde bevaringstilstand og registrering tolkes huset som værende af samme type som husene A452 og A504. Fundmaterialet fra huset var da også af samme karakter som ved disse to huse. I lagene blev der fundet skår fra hjemligt producerede glaserede kander, skår af hjemligt gråbrændt keramik, et skår af importeret Andennekeramik, flere benkamme og kamfragmenter, en træspunds, dele af sko og klæde, jernknive, en mejsel, et jernbidsel, en pilespids, del af en hestesko, kobberbeslag, en synål og diverse nagler og beslag i jern.

Hus A427 blev sandsynligvis bygget i begyndelsen af 1200-tallet. Det var umiddelbar efterfølger til hus A503, der blev bygget i begyndelsen af 1100-tallet. Husets lag indeholdt flere skår af hjemlige glaserede kander, der peger på, at det var i brug efter 1200 . Fire tagbærende stolper og en af vægplankerne blev dendrokronologisk dateret. Alle fem prøver var uden splint og fra træer fældet efter 1090, 1102, 1105, 1143, 1156 og 1156. Tømmerets høje alder i forhold til genstandsmaterialet kan skyldes, at der var tale om genbrugstømmer eller kerneved. En planke fra den tømmerbelagte Algade nord for huset blev dendrokronologisk dateret til 1162-1177. ${ }^{45}$ Denne belægning blev lagt, mens huset var i brug, og planken var sandsynligvis genbrugstømmer muligvis fra nedrivningen af hus A452. Efter huset var nedrevet, blev den vestlige del af grunden inddraget til kirkegård. Den var i brug i en kort periode i slutningen af 1200- eller begyndelsen af 1300-tallet og har sandsynligvis tilhørt Aalborgs gråbrødrekloster, der blev oprettet i 1240'erne. Hus A427 blev derfor sandsynligvis nedrevet omkring midten af 1200-tallet. Huset kan således dateres til ca. 1225-1260.

\section{Hus A428, ca. 1225-1300}

Øst for hus A427 lå det samtidige hus A428 (fig. 20). Dette hus blev ligeledes hastigt udgravet, og tolkningen er derfor behæftet med stor usikkerhed, blandt andet fordi gulvlagene ikke blev registreret i fladen. Huset var mere end 15,3 m langt og over 4,7 m bredt. Lagene i huset var op til $70 \mathrm{~cm}$ tykke, hvilket tyder på en lang brugsperiode.

Taget har været båret af jordgravede stolper, der stod i ydervæggen. Fem stolper stod bevaret i husets vestvæg (fig. 3). Hvis det antages, at der blot var fjernet en enkelt stolpe midt for huset, ville den indbydes afstand mellem stolperne være nogenlunde ensartet, 2,7-3,1 m 
i den nordlige ende og $2 \mathrm{~m}$ i sydenden. Stolperne var alle fuldkantede og rektangulære i tværsnit 12-18x20-34 cm. En tagbærende stolpe i den sydlige del af huset havde desuden notriller i husets længderetning. Denne stolpe havde dog en senere datering og kan være fra en reparation eller ombygning. Væggen bestod af uens stykker af vandret tømmer og mindre pæle samt flere kampesten. Den tolkes som en bulvæg lagt på syldsten, hvor den nederste planke var fastholdt af pæle. Den store afstand mellem de tagbærende stolper kan ligeledes ses som indikation på, at væggene bestod af bulplanker.

Husets ruminddeling var ikke entydig, men det synes som sine to forgængere at have tre rum i husets fulde bredde. Den sydlige skillevæg har ligget på en uens række af kampesten og kan derfor have været identisk med ydervæggen. Den nordlige skillevæg var blot antydet af et formuldet tværgående tømmerstykke, der lå ud for en kraftigere tagbærende stolpe. Såfremt husets ovn var en bilæggerovn, som tilfældet var ved det forrige hus, kan dette også styrke tolkningen af skillevæggen. Som hus A452 var hus A428 bygget på et lag af græstørv, der også udgjorde husets ældste gulv. Ved profilen ud for skillevæggen var tørvegulvet særligt slidt og var repareret ad flere omgange. Denne nedslidning af gulvet kan skyldes megen færdsel på stedet, og det er derfor muligt, at der har været en dør i skillevæggen. I tidens løb blev gulvet flere gange udbedret både med ler og tørv.

Hus A428 havde sandsynligvis tre ildsteder. Den hastige udgravningsmetode gjorde, at de to nordlige ildsteder blev henført til det yngre hus A376. Ved efterbearbejdningen blev det klart, at ildstederne sandsynligvis tilhørte hus A428. De to nordlige ildsteder afløste hinanden og lå i husets nordlige rum. Det ældste var et åbent ildsted, der bestod af et lerlag med en forsænkning til ilden. Det yngre var sandsynligvis også et åbent ildsted, og var ligeledes af ler, men bestod desuden af sten. Hovedildstedet var en stor ovn, der lå i husets midterste rum, var $158 \mathrm{~cm}$ bred og mere end $160 \mathrm{~cm}$ lang, mens selve ovnkammeret var $112 \mathrm{~cm}$ bredt. Ovnkappen var ved foden 20-24 cm tyk, og der var rester efter de lodrette vidjer fra ovnkappens skelet. Trods den hastige registrering af ovnen synes der ikke at være tvivl om, at ovnen var af samme type som ovnene i husene A504 og A452. Indfyringen må derfor antages at have været ved den mulige skillevæg mod nord.

Huset har sandsynligvis været af samme type som de forrige A452 og A504. Det nordlige og det midterste rum har derfor sandsynligvis været husets beboelsesdel. Genstandsfundene adskilte sig ikke fra fundene i de xldre middelalderhuse, og det kan derfor formodes, at beboerne har tilhørt samme lag, som de der boede i husene fra det forudgående århundrede. Tre vægtlodder, en glasperle, keramikskår af den nordfranske Rouen-type, fragmenter af en bageplade og et kar af norsk klæbersten og flere hvæssesten af norsk skiffer vidner om internationale forbindelser. En hummerklo opfyldt med bly kan være et fiskelod eller mere kuriøst en amulet. Desuden fandtes hjemlige gråbrændte keramikskår, skår af glaserede kander, to tenvægte af bly og en tenvægt af keramik, bronzebeslag, et stegespid i jern, flere knive, en pilespids, diverse søm og beslag i jern, to bennåle, to små dobbeltkamme i ben og et muligt stykke legetøj af knogle.

Hus A428 blev sandsynligvis bygget i begyndelsen af 1200-tallet og var i brug frem til omkring 1300. To dendrokronologiske dateringer angiver husets opførelsestidspunkt, en prøve var uden splint og stammede fra et træ fældet efter 1180, mens en anden var fra et træ fældet i perioden 1147-1162. Begge prøver stammede fra tagbærende stolper i husets nordende. Da de dendrokronologiske dateringer var sammenfaldende med dateringen af hus A452, der var stratigrafisk ældre, kunne det tyde på, at huset delvist blev bygget af genbrugstømmer. Fra sydenden hidrørte én dendrokronologisk datering fra en tagbærende stolpe, der stammede fra et træ fældet efter $1274 .{ }^{46}$ Stolpen har derfor sandsynligvis været anvendt ved en renovering eller ombygning i slutningen af 1200 -tallet. Den sene datering viser desuden, at huset har været i brug over en lang periode. Det blev nedrevet ved opførelsen af hus A376 i begyndelsen af 1300-tallet. Den formodede brugstid har derfor været ca. 1225-1300. 


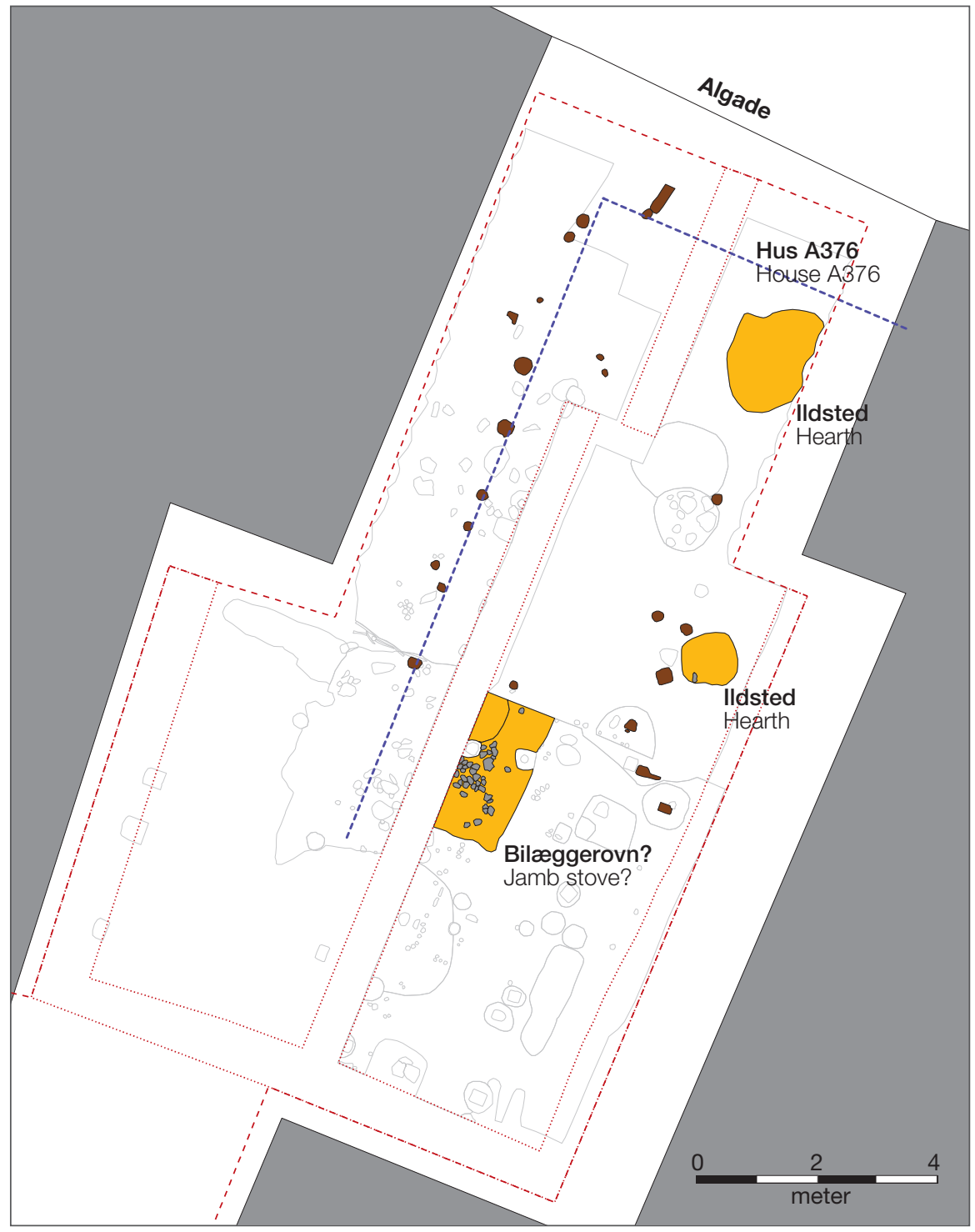

Fig. 21. Plan over hus A376, ca. 1300-1350. Planen viser registreringsniveau 6. Husets sandsynlige vestvæg og nordgavl er stiplet ind.

Plan of house A376, c. 1300-1350, at recording level 6. The building's likely west wall and north gable are shown with broken lines. 


\section{Hus A376, ca. 1300-1350}

Dette hus blev absolut ikke undersøgt optimalt, og det må grundlæggende beskrives som en række husrelaterede anlæg, der tolkes som sammenhørende (fig. 21). Der er derfor uklarhed med hensyn til husets grundplan, men længden har været mindst $12 \mathrm{~m}$ og bredden mindst $5 \mathrm{~m}$. Kirkegården mod vest var i brug samtidig med huset.

Husets formodede vestlige ydervæg udgjordes af en uregelmæssig stolperække, som var den eneste konstruktion, der kendes fra huset. Stolperne var tilspidsede forneden og tilsyneladende banket i jorden. De var runde, og diameteren varierede fra $18-30 \mathrm{~cm}$ og havde sandsynligvis båret taget.

Tre ildsteder blev tolket som en del af huset. De to nordligste fremstod som varmepåvirkede lerlag og uden en egentlig opbygning. Det tredje ildsted var sandsynligvis en ovn, som målte $260 \times 120 \mathrm{~cm}$ opbygget af ler med et indre lag af nævestore sten. Tre indre stenhorisonter viste, at ovnen var ombygget mindst to gange. Der var ikke spor efter ovnkappen, men ligheden med ovnene i hus A504, A452 og A428 sandsynliggør, at dette ildsted var af samme type.

Hus A376 opfattes som et hus af samme type som de yngre A504, A452 og A428. Tolkningen er dog behæftet med stor usikkerhed. Udgravningens ældste skår af rhinsk stentøj blev fundet i lag tilhørende huset. Derudover fandtes skår af hjemligt gråbrændt keramik, skår af hjemlige glaserede kander, en blytenvægt, et vægtlod, kobberbeslag, en jernnøgle, diverse søm og beslag i jern og et fragment af en hvæssesten.

Dateringen af huset er usikker. Skårene af rhinsk stentøj peger på en funktionstid i 1300-tallet, og det var stratigrafisk yngre end A428, der stadig var i brug efter 1274. Det tyder på, at huset blev opført i begyndelsen af 1300-tallet. Efter nedrivningen blev grundene i området samtidigt saneret. De efterfølgende huse respekterede derfor ikke de gamle skel fra 1000-tallet. Dette skete sandsynligvis ved midten af 1300-tallet. Dateringsmæssigt tilhører huset perioden ca. 1300-1350.

\section{Hus A350, ca. 1350-1355}

Hus A350 var en staldbygning, der lå sydligst i feltet (fig. 22). Det var i udgravningssituationen uklart, om A350 var et egentligt hus eller blot et halvtag. Orienteringen af huset synes at være øst-vest, og bredden var da 5,8 m, mens længden var mere end $5 \mathrm{~m}$. Huset havde sandsynligvis en meget kort levetid, hvor der tilsyneladende ikke var bebyggelse på den nordlige del af grunden op mod Algade.

Taget var båret af jordgravede stolper. Flere stolper kan have været tagbærende, og det var usikkert, hvordan konstruktionen har været. Huset var omgivet af fire forløb af fletværk af vidjer flettet omkring støjler med en diameter på 6-12 cm (fig. 4). Det er nok mest sandsynligt, at forløbene afspejler hegn, men drejer det sig om vægge, kan et eller flere af forløbene hidrøre huset.

Husets gulvareal var dækket af planker, der var ordnet i tre grupper i forlængelse af hinanden. Plankerne var af løvtræ og dækkede 5,8x3 m på tværs gennem huset. De var lagt på strøer af mindre grene, og en enkelt af disse var egetræ. Under plankerne var flere måtter af fletværk, der hovedsageligt var orienteret med vidjerne i samme retning som plankerne. Fletværksmåtterne lå direkte under plankerne og må være udlagt som underlag for disse. Hen over belægningerne lå et 10-20 cm tykt brugslag bestående af dyrefækalier og strå.

På baggrund af brugslaget tolkes huset som en stald. Makrofossilundersøgelserne viste, at der var en meget lille nedbrydningsgrad i brugslaget, hvilket indikerer en meget kort levetid for huset. ${ }^{47}$ Der var fire forløb af fletværk omkring huset, hvilket muligvis kan 


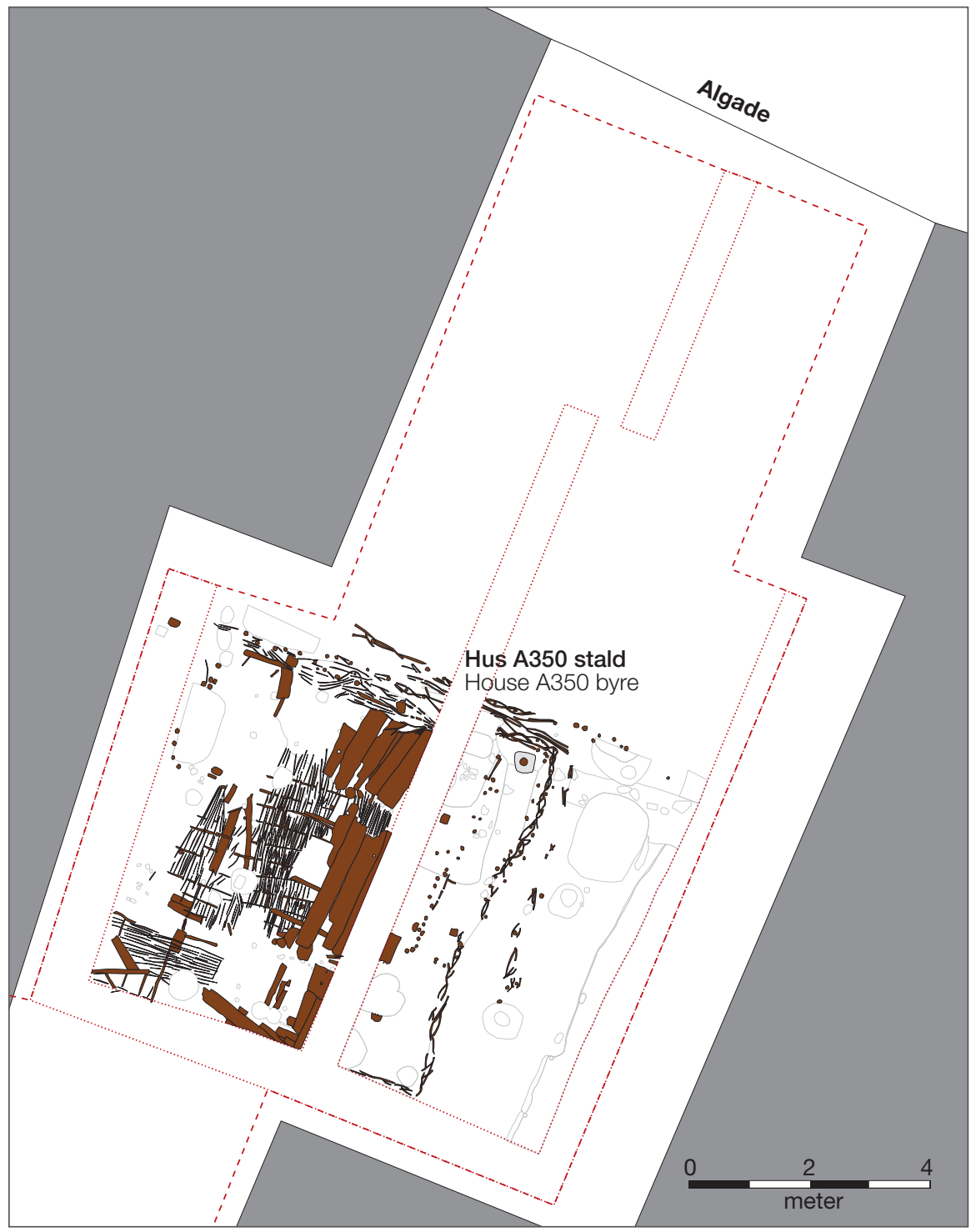

Fig. 22. Plan over hus A350 inklusiv tilhørende fletværkshegn, ca. 1350-1355. Planen viser registreringsniveau 5 .

Plan of house A350 including associated wattle fence, c. 1350-1355, at recording level 5. 
tolkes som en brugsperiode på fire år. I lagene blev der fundet flere fragmenter af hestesko, hvilket kunne tyde på, at det har været en hestestald. De øvrige genstandsfund var skår af gråbrændt hjemligt keramik, skår af hjemlige glaserede kander, skår af rhinsk stentøj, to låse, et remendebeslag, et stykke kobbertråd, jernknive, diverse søm og jernbeslag, tilvirket tak, en rebstump, en sko, en stav fra et stavbæger, en drejet træskål, et fragment af en hvæssesten og et intakt hønseæg.

Huset følger umiddelbart efter hus A376, der var i brug i 1300-tallet. Det respekterer ikke det skel, der havde været på grunden siden 1000-tallet. Et område af byen må derfor være blevet saneret og skellene ophævet. Den sorte død i 1349-1351 kan være årsagen. Huset har som nævnt sandsynligvis en meget kort brugsperiode. Omkring midten af 1300-tallet blev huset fjernet til fordel for huset A762 og smedjen A344. En sandsynlig levetid for hus A350 må være 1350-1355.

\section{Hus A762, ca. 1355-1400}

Ved opførelsen af A762 var der igen et beboelseshus på grunden (fig. 23). Det var mere end $5,2 \times 4,8 \mathrm{~m}$ stort. Den nordlige del af grunden var bortgravet af en renæssancekælder, og derfor kunne det ikke påvises, om huset var orienteret parallelt eller vinkelret på Algade. Hvis huset som de fleste øvrige huse på grunden havde nordgavlen ud mod Algade, har husets grundplan været ca. 10x5,5 m. De lag, der hidrører til huset, blev først udskilt fra hus A211 i bearbejdningsfasen, og det kan derfor ikke afvises, at der er sket en vis sammenblanding. Huset har sandsynligvis været samtidigt med smedjen A344.

Husets lergulv blev mod syd afgrænset af en grøft med enkelte kampesten og en enkelt stolpe. Dette var de eneste spor efter husets konstruktion. Sandsynligvis repræesenterede grøften sporet efter en fjernet fodrem. I det sydvestlige hjørne af huset var en stolpe, der kan have været en del af en nord-syd orienteret skillevæg eller en indre konstruktion i huset.

Der var mindst et ildsted i huset. Dette viste sig blot som et varmepåvirket område på $30 \times 50 \mathrm{~cm}$. De sparsomme spor efter ildstedet kan være et udtryk for, at ildstedet har været opbygget over gulvet $\mathrm{i}$ en konstruktion, der ved nedrivningen af huset var blevet fuldstændigt fjernet.

Hus A762 tolkes på baggrund af ildstedet som et beboelseshus. Huset var dog meget dårligt bevaret, og det kan derfor ikke afvises, at det har haft en anden funktion. Det meget sparsomme genstandsmateriale adskilte sig ikke fra de øvrige beboelseshuse. Der var keramikskår fra hjemlige gråbrændte potter, fra hjemlige glaserede kander og rhinsk stentøj, en lysestabel i jern, et spænde, et kobberbeslag og en ubestemt mønt.

Huset blev opført efter stalden A350 og var i brug samtidigt med smedjen A344. Smedjen blev bygget i midten af 1300-tallet. Opførelsen af hus A762 må derfor på dette lidt usikre grundlag dateres til midten af 1300-tallet. Det blev nedrevet i slutningen af 1300-tallet, hvor det efterfølgende hus A221 blev opført. Huset må da tilskrives perioden ca. 1355-1400.

\section{Hus A344, ca. 1355-1400}

Godt en meter syd for A762 fandtes huset A344, der blev tolket som en smedje (fig. 23). Da det var meget forstyrret af en yngre kælder, blev det i udgravningssituationen fejltolket, og hovedparten af tolkningen hidrører derfor fra efterbearbejdningen. Smedjen målte 4,3x7 $\mathrm{m}$ orienteret øst-vest, og den var i brug samtidigt med hus A762.

Den bærende konstruktion bestod af fire stolper i husets ydervægge mod nord og sandsynligvis det samme mod syd. Afstanden mellem stolperne var mellem 2 og 2,5 m. To af stolperne havde fuldkantet kvadratisk tværsnit på 16x16 og 13x13 cm. De øvrige var utilhuggede med en diameter på 15-18 cm. Det uensartede tømmer kunne tyde på, at der 


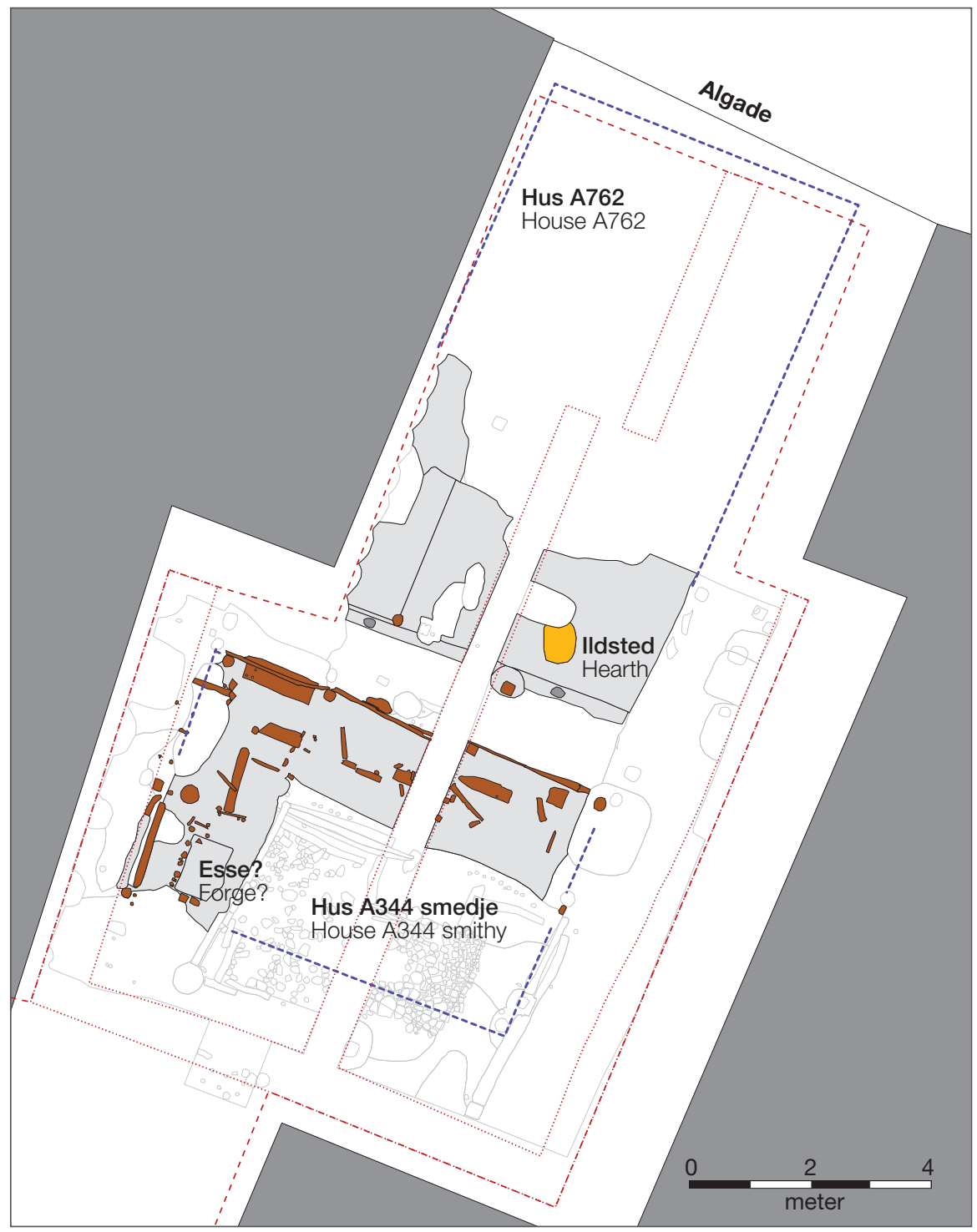

Fig. 23. Plan over hus A762, ca. 1355-1400 og hus A344, ca. 1355-1400. Planen viser registreringsniveau 4. Tolkningen af hus A762 som gavlhus og de manglende ydervægge ved hus A344 er stiplet ind.

Plan of house A762, c. 1355-1400, and house A344, c. 1355-1400, at recording level 4. The interpretation of house A762 as a gable house, and the missing outer wall of house A344, are shown with broken lines. 
i konstruktionen indgik genbrugstømmer. Omtrent midt for gavlene var der yderligere en stolpe, der også kan have haft en bærende funktion. Væggen bestod af planker fastgjort på stolpernes yderside, sandsynligvis var de naglet fast.

Husets funktionslag indeholdt store mængder slagger, og den vestlige del af huset bærer præg af, at der har været ild. I husets sydvestlige hjørne var der rester efter en rektangulær konstruktion, der var hævet over gulvet, og som kan være spor efter essen. Nord for denne var en stolpe med en diameter på $30 \mathrm{~cm}$, der var brændt i toppen og muligvis repræsenterer resterne af en armboltsstok. Spredt over brugslaget, men under husets nedbrydningslag, var en del tømmerstykker af uvis funktion. I huset var der foruden slaggerne, gråbrændt hjemlige keramikskår, skår efter hjemlige glaserede kander, skår af stentøj fra Rhinegnen og Sachsen, skår af et drikkeglas, en ravperle, nøglefragmenter i kobber, kobberbeslag, et kistelåg med jernbeslag, jernknive, diverse nagler og beslag i jern, en knage af tak, lædersko, tekstilfragmenter, spundet dyrehår og et stykke skibstømmer.

Smedjen blev opført, efter stalden A350 var nedrevet, og den var i brug i slutningen af 1300 -tallet. Tre træprøver fra tømmeret i husets nordvæg blev dendrokronologisk dateret til efter 1272, efter 1326 og efter $1329 .{ }^{48}$ Prøverne var uden splintved, og huset kan være opført af genbrugstømmer. Et stentøjsskår fra Waldenburg i Sachsen peger mod slutningen af 1300-tallet. Skåret blev fundet i et brandlag, der henføres til den sidste del af husets brugstid. Huset blev nedrevet inden hus A244, der blev bygget omkring år 1400. Hus A344 har da sandsynligvis været i brug i perioden ca. 1355-1400.

\section{Hus A221, ca. 1400-1475}

Dette hus lå centralt på grunden og respekterede grundens nuværende matrikelskel (fig. 24). Det har sandsynligvis været et gavlhus med nordenden ud mod Algade. Den nordligste del var dog bortgravet ved anlæggelsen af en kælder i 1574. Huset har været ca. 16,5 m langt og 5,5 m bredt og havde en kælder i den sydlige del. Dets ydervægge var sammenfaldende med det efterfølgende hus A55.

Huset var bygget med jordgravede stolper eller pæle i ydervæggene. I østvæggen var fem bevaret, mens der blot var én i vestvæggen. Hovedparten af de bevarede stolper/pæle var i sydendens kælder. Stolperne i den del, hvor der ikke var kælder, kan have været ført op til tagremmen, men kan også være piloteringspæle under en fodrem. Flere af stolperne/ pælene var meget formuldede, men det så ud til, at de alle har været fuldkantede med dimensionerne $18-25 \times 20-30 \mathrm{~cm}$.

Sydendens kælder var gravet ca. $70 \mathrm{~cm}$ ned i jorden, men da den blev nedgravet på skrånende terræn, svarede gulvniveauet i sydenden næsten til det omgivende terræn. Kælderen var $3,8 \times 5,5 \mathrm{~m}$ med en stolpe i hvert hjørne samt en midt for hver side. Stolperne var fuldkantede med dimensionerne $18-25 \times 20-30 \mathrm{~cm}$. Den vestlige side havde dog i stedet fire lidt mindre tætstillede stolper. Disse var ligeledes fuldkantede og var 9-11 x12-14 cm. Som ved den øvrige del af huset var det muligt, at stolperne blot var ført op til husets mulige fodrem.

På ydersiden af stolperne var der vandrette tømmerstykker, der har udgjort den nederste del af vægudfyldningen. Den nordlige væg bestod af fire tømmerstykker af kløvede stammer på 12-24 cm i diameter og den vestlige af to kløvede og en ukløvet stamme på ca. $15 \mathrm{~cm}$. Tømmerstykkerne var ikke fastgjort til stolperne, men blev holdt på plads af den bagvedliggende lerfyld i kældernedgravningen. Vægtømmeret i den østlige væg udgjordes af et enkelt vandretliggende tømmerstykke. Det var et oprindeligt fuldkantet tømmerstykke på $25 \times 25 \mathrm{~cm}$, der var tilhugget, så det passede ind i konstruktionen. Der var også hugget ud til stolpen midt for vestvæggen. Der var således ikke tvivl om, at dette tømmerstykke var genbrug. Af kælderens sydlige væg var der kun bevaret et enkelt tømmerstykke helt mod vest. Oven på tømmerstykkerne var der mod øst, vest og syd notriller, der kunne 


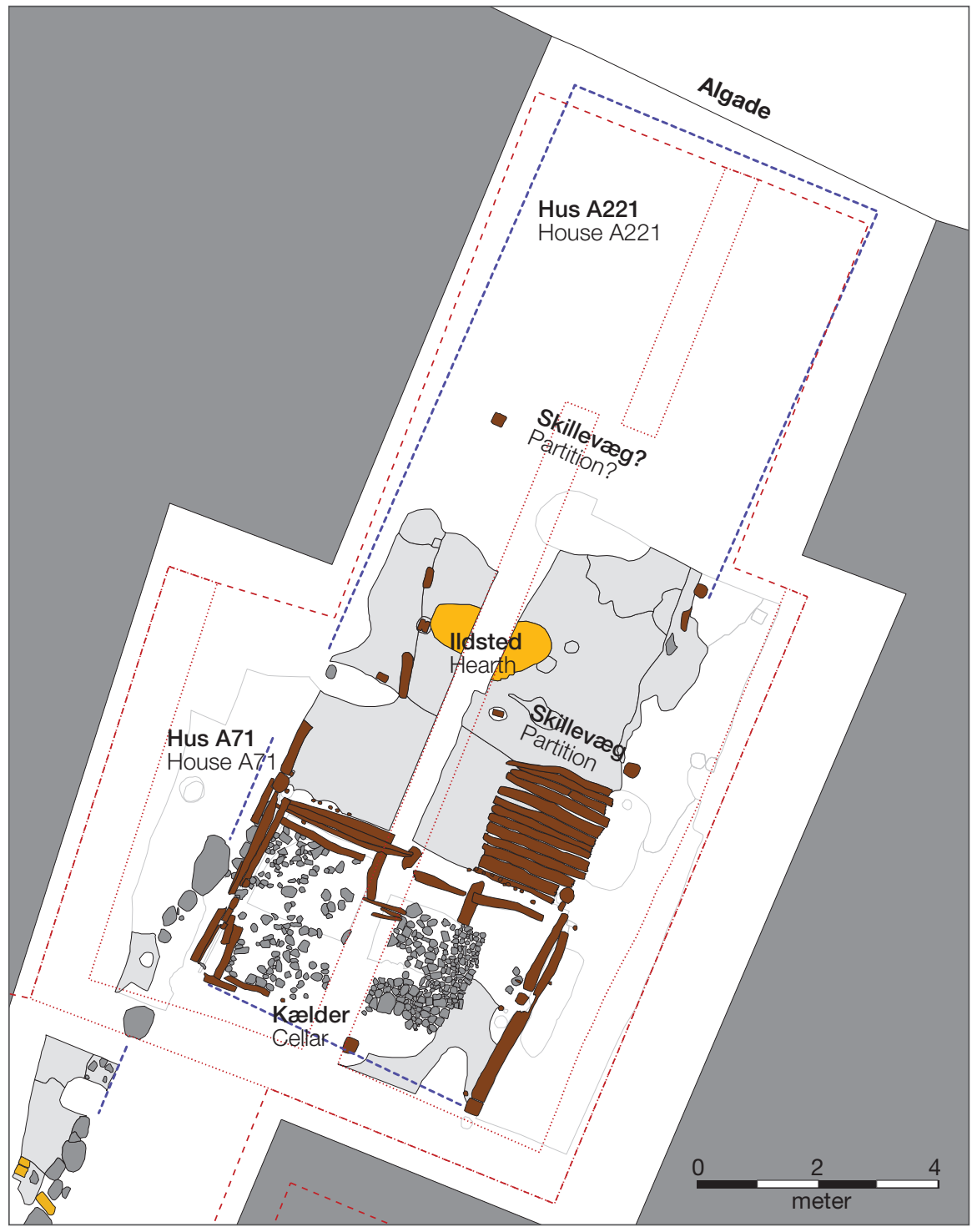

Fig. 24. Plan over hus A221, ca. 1400-1475 og hus A71, ca. 1425-1475. Planen viser registreringsniveau 3 med anlæg fra niveau 4. De sandsynlige vægforløb er stiplet ind. Teglsten er vist med gult.

Plan of house A221, c. 1400-1475, and house A71, c. 1425-1475, at recording level 3 and with features from recording level 4 . The likely course of the walls is shown with a broken line. Bricks are shown in yellow. 
tyde på, at væggen har været af fletværk. Kælderens nordlige væg op mod det resterende hus A221 var af fletværk. Vidjerne var flettet om støjler, der stod i gulvet over kælderens nedre tømmervæg. Fletværksvæggen levnede ikke umiddelbart nogen plads til en dør, og indgangen har derfor sandsynligvis været mod syd.

Gulvet i kælderen bestod af en pikstensbelægning, som bestod af næve- til hovedstore sten med et fåtalligt indslag af teglstensfragmenter. Der var ikke piksten langs væggene i kælderens østlige halvdel, hvor der blot var lergulv. Vinkelret på nordvæggen over lergulvsdelen var to tømmerstykker, der blev tolket som en trækonstruktion, der har skullet hæve tønder, kar eller lignende op fra gulvet. En lignende konstruktion har muligvis været langs den vestlige og sydlige væg.

Den øvrige del af hus A221 var af skillevægge delt i mindst to, men muligvis tre rum (fig. 12). Den sydlige skillevæg udgjordes af to jordgravede stolper, og begge var fuldkantede og rektangulære i tværsnit. Den mulige nordlige skillevæg blev tolket ud fra en enkelt fuldkantet stolpe, der niveaumæssigt bør tilhøre hus A221, men som i øvrigt var løsrevet fra stratigrafien.

Der var ikke bevaret kulturlag fra det mulige nordligste rum. Rummet syd herfor havde lergulv i to faser. I begge faser var der centralt på gulvet varmepåvirkede områder, der tolkes som rester af to ildsteder, der havde efterfulgt hinanden. Der blev ikke gjort iagttagelser, der kunne indikere, om der var tale om åbne ildsteder eller ovne. Rummet syd for var et smalt rum, der mod øst havde en belægning af 12 kløvede træstammer. Tømmerstykkerne var lagt parallelt og tæt sammen, således at de udgjorde en nærmest rektangulær flade, der målte ca. 210x $190 \mathrm{~cm}$. Stammerne var 12-20 cm i diameter og 180-188 cm lange. Resten af gulvfladen var dækket af brugslag af trækulsstykker og små slagger.

Rummet med ildstedet indgik sandsynligvis i beboelsesdelen som køkken og opholdsrum. Ligeledes må det mulige rum nord for ud mod Algade have været et beboelsesrum. Fund af gråbrændte kakkelskår vidner om, at der i beboelsesdelen kan have været en kakkelovn. Rummet mod syd var sandsynligvis ikke en del af husets boligdel, men har snarere været et gennemgangsrum eller værksted. Kælderrummet har sandsynligvis været brugt til opbevaring.

Fundene i huset var skår efter gråbrændt hjemligt keramik, skår fra hjemlige glaserede kander og trebenede potter, skår af rhinsk stentøj, skår af drikkeglas, et Skt. Hjælper pilgrimsmærke, en sølvmønt, nøden og en skinne til en armbrøst, knive og redskaber i jern, en lås, kobberbeslag, diverse søm og beslag af jern, en smeltedråbe af bly, rester af flere sko, diverse dele af tønder og skibe og diverse formsten i tegl. Fund af importeret keramik, glas og våben tyder pa, at husets beboere har været forholdsvis velstående.

Hus A221 blev sandsynligvis bygget omkring år 1400. Den fundne mønt er ældre end $1379 \mathrm{og}$ blev fundet $\mathrm{i}$ et af husets yngre smudslag. ${ }^{49}$ I en grube umiddelbart øst for husets kælder blev en kobbersterling fra 1420-35 fundet. ${ }^{50}$ Gruben blev dækket inden nedrivningen af huset, og mønten daterer derfor husets brugstid til 1400-tallet. Pilgrimsmærket fra Skt. Hjælper blev fundet i kælderens opfyldslag. Mærket kendes fra fire afstøbninger på danske kirkeklokker. Tre af klokkerne er dateret med årstal til henholdsvis 1458, 1465 og 1473. Den fjerde klokke er dateret til anden halvdel af 1400 -tallet. ${ }^{51}$ Huset blev derfor sandsynligvis nedrevet i slutningen af 1400-tallet. Hus A55 blev bygget umiddelbart herefter. Sandsynligvis var hus A221 i brug i perioden ca. 1400-1475.

\section{Hus A71, ca. 1425-1475}

Sydligt på grunden vest for hus A221 fandtes hus A71 (fig. 24). Det lå hovedsagelig på nabogrunden mod vest, hvorfor det kun blev delvist undersøgt. Længden var mere end 
7,7 m, og bredden var over 2,5 m. Huset kan som A221 have været et gavlhus til Algade og har da været ca. $22 \mathrm{~m}$ langt. Huset var i brug samtidigt med A221.

Huset blev opført på en syld af store kampesten, og der var ikke jordgravede dele. Huset må derfor have været et bindingsværkshus. Inden for syldstenene fandtes lergulve i to faser. I den sydlige ende af huset fandtes nogle halve munkesten, der var lagt i sand. Sandlagets udstrækning viste, at belægningen har været større. Den ene munkesten var sekundært varmepåvirket, og belægningen kan have været fra et ildsted.

Med den sparsomt undersøgte del kan det ikke afgøres med sikkerhed, hvorledes hus A71 skal forstås. Huset kan tolkes som et gavlhus med beboelse, der lå side om side med A221. Genstandsfundene fra huset mindede da også om genstandene fra de øvrige beboelseshuse fra udgravningen. Der var hjemligt gråbrændte keramikskår, skår af hjemlige indvendigt glaserede potter, stentøjsskår, flere skår af samme glaserede muligvis importerede potte, en jernøgle, en kniv og en sko.

Hus A71 blev bygget efter opførelsen af hus A221, og husene har fungeret på samme tid. Begge huse blev nedrevet samtidigt, ved opførelsen af hus A55 i slutningen af 1400-tallet. Husets brugstid kan dateres til ca. 1425-1475.

\section{Hus A55, ca. 1475-1574}

Hus A55 var meget lig hus A221 og havde også omtrent samme udstrækning (fig. 25). Den nordlige del af huset var bortgravet i forbindelse med anlæggelsen af en yngre kælder, men sandsynligvis var det et gavlhus med nordenden mod Algade. Det har været ca. $19 \mathrm{~m}$ langt og 5,5 m bredt. Som ved hus A221 havde huset i sydenden en kælder, som var 4x5,5 m stor. Huset var nedbrændt.

Huset havde i den sydlige del formuldede fodremme, der var lagt direkte på jorden. Ved enderne af fodremmen var der syldsten, der sandsynligvis har båret husets stolper. En sandsynlig tolkning er, at der har været syldsten under alle husets stolper.

Kælderen i husets sydende var bygget med jordgravede stolper - en i hver hjørne og en omtrent midt for hver langside (fig. 13). Mod nord var der en stolpe på hver side af kældertrappen. Stolperne var tilsyneladende ikke tilhuggede og var 19-28 cm i diameter. Væggen mod nord var repræsenteret ved tre vandrette kløvede stammer, der havde en diameter på ca. $20 \mathrm{~cm}$. Mod vest bestod væggen af lodrette tømmerstokke og mod syd af lodrette planker. På indersiden var der rester efter planker, og der kan således have været en indvendig vægbeklædning. En anden mulighed er, at den vandrette planke blot har fikseret de nedre ender af det lodrette tømmer. Den østlige halvdel af kælderen var ødelagt af et moderne trappetårn til det endnu stående baghus.

Kælderen var i den nordlige ende nedgravet $62 \mathrm{~cm}$, sandsynligvis lidt mindre mod syd, da terrænet skrånede. Der var sikkert adgang til kælderen fra nord og fra syd. Fra nord førte en trappe fra huset ned til kælderdøren. Trappens tre trin var $20-22 \mathrm{~cm}$ brede planker, der var naglet fast til to underliggende strøer. Trappen var $1 \mathrm{~m}$ bred, og det øverste trin svarede i niveau til husets gulv. Neden for trappen var der rester af en dørplade. Den var $95 \mathrm{~cm}$ bred og var samlet af fire planker med en tværgående revle af træ. Plankerne var $19-32 \mathrm{~cm}$ brede og havde en tykkelse på $3 \mathrm{~cm}$. De var samlet med fjer og not. Resterne af et muligt gangjern sad vestligt på dørpladen i en højde på $32 \mathrm{~cm}$. Dette tyder på, at døren var hængslet i den vestlige side. Et $10 \mathrm{~cm}$ bredt bundstykke var tappet ind i dørens karmtræ. Den anden mere usikre adgang befandt sig i det sydvestlige hjørne. Her var pikstensgulvet ført helt ud til væggen, hvilket kan ses som udtryk for, at der har været færdsel. Desuden fandtes der i kælderens opfyldslag to klinkefaldslåse, hvilket indikerer to døre.

Ud over kælderen var den bevarede del af huset delt i to rum. Skillevæggen har stået på en fodrem, der blot var bevaret i form af et omsat træspor. En syldsten vest for husets store 


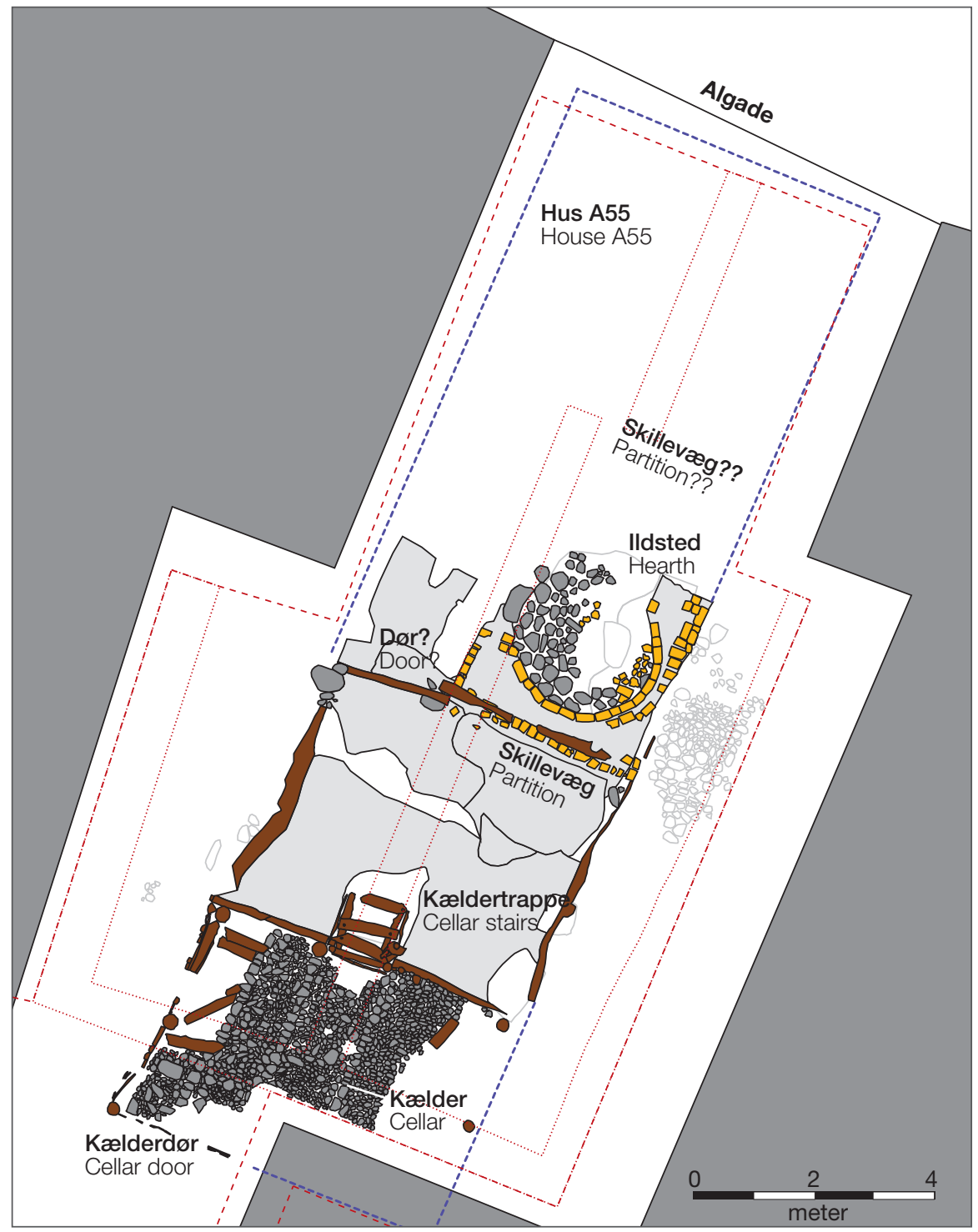

Fig. 25. Plan over hus A55, ca. 1475-1574. Planen viser registreringsniveau 1 og 2 med anlæg fra niveau 0 . De sandsynlige vægforløb er stiplet ind.

Plan of house A55, c. 1475-1574, at recording levels 1 and 2 with features from level 0. The likely course of the walls is shown with a broken line. 
ildsted kunne indikere en dørstolpe. Døren har da været $132 \mathrm{~cm}$ bred. En nærliggende tanke er, at også den ikke bevarede nordlige del af huset var delt i to rum, således at husets planløsning mindede om den, man finder ved 1500-tallets bindingsværkshuse. ${ }^{52}$ Denne tolkning kan dog ikke underbygges yderligere.

I husets mulige midterste rum var et $330 \times 340 \mathrm{~cm}$ stort ildsted, der var opbygget af munkesten og ler (fig. 14). Langs syd- og østsiden var en halvcirkulær opbygning af munkesten. Halvcirklen havde en indre radius på $110 \mathrm{~cm}$ og var bevaret i op til fire skifter. Kun få af stenene var hele, og de var desuden meget varmepåvirkede. Mod vest og nord afsluttedes opbygningen nogenlunde vinkelret på halvcirkelslaget, hvilket indikerer en vange til en åbning ind mod belægningen i halvcirklen. Ydersiden af ildstedet var opbygget med hele og halve munkesten. Imellem den indre halvcirkel og ydersiden var der leropfyldning. Mod syd gik leret lidt uden for teglvæggen til det formuldede spor efter skillevæggen. Fladen inde i ildstedet var belagt med sten dækket med fint sand. Belægning havde hele anlæggets kvadratiske udstrækning. Over den østlige del af stenbelægningen var halvanden munkesten, der viste, at ildstedets brugsflade formentlig har været på en belægning af munkesten. Ildstedet tolkes som et åbent ildsted med en skorsten eller halvcirkulær hvælvet overbygning.

Gulvene i de to rum i huset var af ler og havde spor efter mange reparationer og horisonter. Kældergulvet var dækket med piksten, nævestore sten med baner af større sten. Der var ikke smudslag på pikstensgulvet, som dermed må have været omhyggeligt renholdt. Mod syd-, øst- og vestvæggen var en ca. $80 \mathrm{~cm}$ bred kant uden piksten. Mod vest var der fire løstliggende tømmerstokke orienteret vinkelret på væggen. Tømmerdelene tolkes som rester af en konstruktion, der har skullet hæve eventuelle tønder, kar eller lignende op fra gulvet. I kælderen i det ældre hus A221 var en lignende konstruktion.

Hus A55 har foruden det store åbne ildsted sandsynligvis også haft en kakkelovn. Selvom der ikke blev fundet nogen konstruktion, var der i husets lag mere end 14 skår af glaserede og uglaserede pottekakler fra en kakkelovn. Det kan ikke umiddelbart afgøres, hvor ovnen har været, men den kan have stået i det mulige nordligste rum, som det ses ved flere af 1500-tallets huse i Aalborg. Hus A55 var brændt, men inden branden var kælderen fyldt op. Kælderen har derfor ikke været i brug i den sidste del af husets tid.

Genstandsfundene i huset var overordnet set de samme typer som ved hus A221. Der blev i huset fundet skår af rhinsk- og sachsisk stentøj, rudeglas, fragmenter af malmgryder og en armbrøstnød, fund der alle peger på en vis velstand. De øvrige fund fra husets lag var skår af gråbrændt hjemligt keramik, skår af hjemlige glaserede kander og potter, en kugle af keramik, der måske var et stykke legetøj, en synål, et kobberspænde, et fingerbøl, kobberbeslag, en knivendedup af bly, to gangjern, to låse, diverse søm og beslag af jern, en benkam, en benperle, et klædefragment og rester af en sko.

Hus A55 blev bygget umiddelbart efter, at hus A221 var nedrevet. Opførelsestidspunktet er derfor bredt dateret til i slutningen af 1400-tallet. Stentøjsskårene fra husets lag henføres alle til 1400- og 1500-tallet. Fra kælderens nordlige væg haves to dendrokronologiske dateringer. Den ene var uden splint og var fældet efter 1408 - en teminus post quem datering der stemmer overens med ovenstående datering. Den anden datering gav det højst uventede fældningstidspunkt $1139 .{ }^{53}$ Der må derfor enten være tale om meget gammelt genbrugt træ eller om en fejl i hele prøvetagnings- og dateringsprocessen. Denne prøve er derfor vanskelig at anvende i forbindelse med dateringen af huset. Huset brændte kort inden 1574, hvor det efterfølgende hus A100 blev bygget. Husets datering må da være ca. 1475-1574.

\section{Hus A100, 1574-2007}

Der er her tale om det bindingsværkshus, der havde stået på grunden Algade 9 i 433 år. 

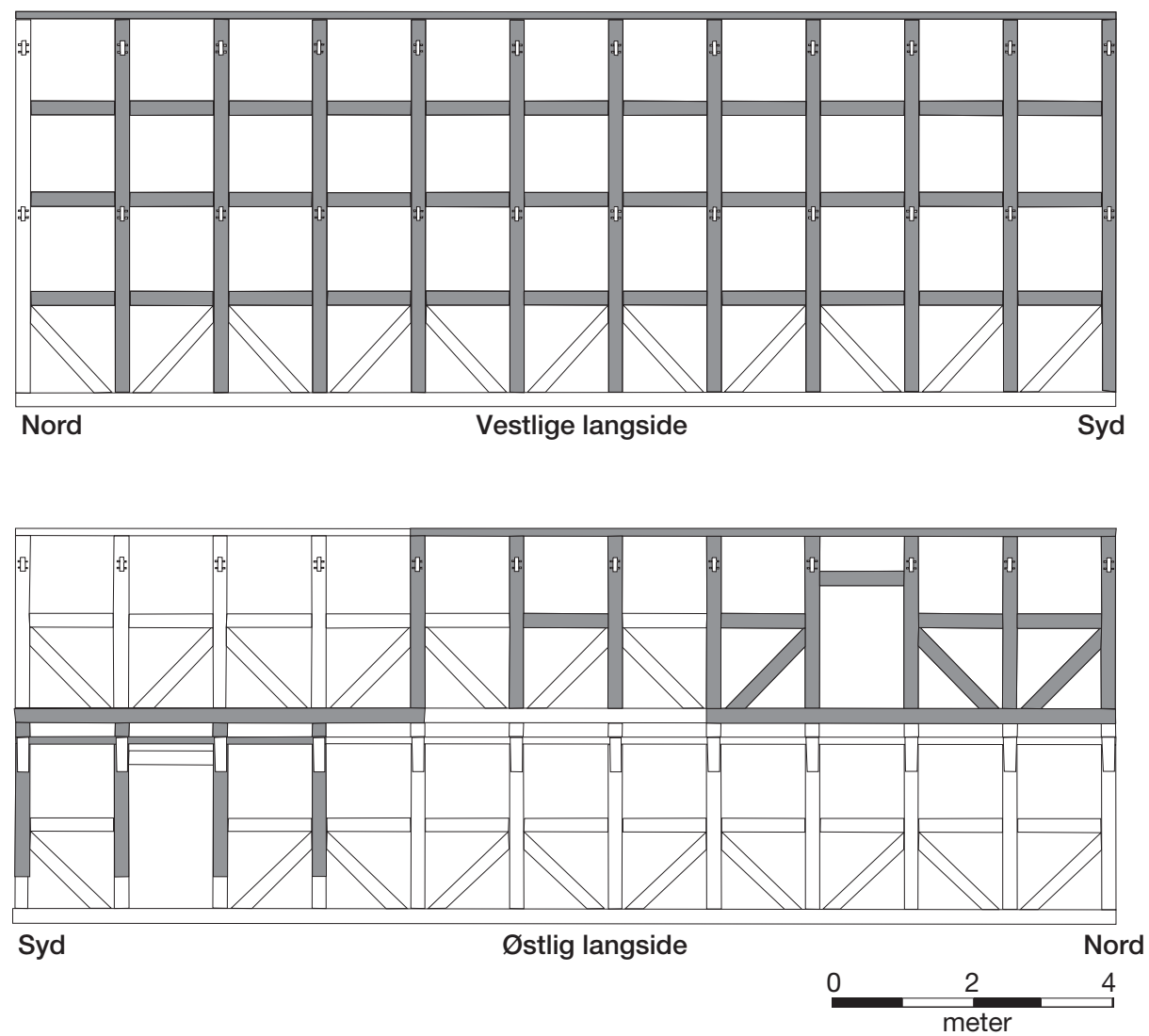

Fig. 26. Rekonstruktion af langsiderne ved A100. Bindingsværkskonstruktionen er set udefra. Med mørk udfyldning ses de dele af det oprindelige bindingsværk fra 1574, der stadig var bevaret ved nedrivningen i 2007.

Reconstruction of the sides of house A100. The half-timbered construction is seen from the exterior. The dark shading marks part of the original timber construction from 1574, which still survived on demolition of the building in 2007.

Det blev nedrevet i 2007. Huset var et 11 fag langt gavlhus i to stokværk. Huset havde en længde på 15,8 m. Bredden var i første stokværk 6,15 m. I andet stokværk var huset $23 \mathrm{~cm}$ bredere, da stokværket var udkraget mod øst. Under de tre nordligste fag havde huset en lav kampestensbygget kælder, hvortil der var adgang fra Algade. Huset blev ikke bygningsarkæologisk undersøgt ved nedrivningen, men enkelte skitser, opmålinger af enkelte fag og fotos fra nedrivningen gør det muligt at beskrive dele af husets oprindelige udformning (fig. 26).

Huset havde gennemgået store ændringer siden dets opførelse. Således var blandt andet nordgavlen, husets facade mod Algade, blevet udskiftet med en grundmuret gavl. Hele den vestlige langside og den sydlige gavl stod dog endnu i bindingsværk i 2007, mens en stor del af den østre langsides bindingsværk var blevet udskiftet med grundmur og jernkonstruktioner (fig. 27).

Bindingsværkstømmeret var af eg og havde generelt et rektangulært tværsnit på 22x15 cm. 


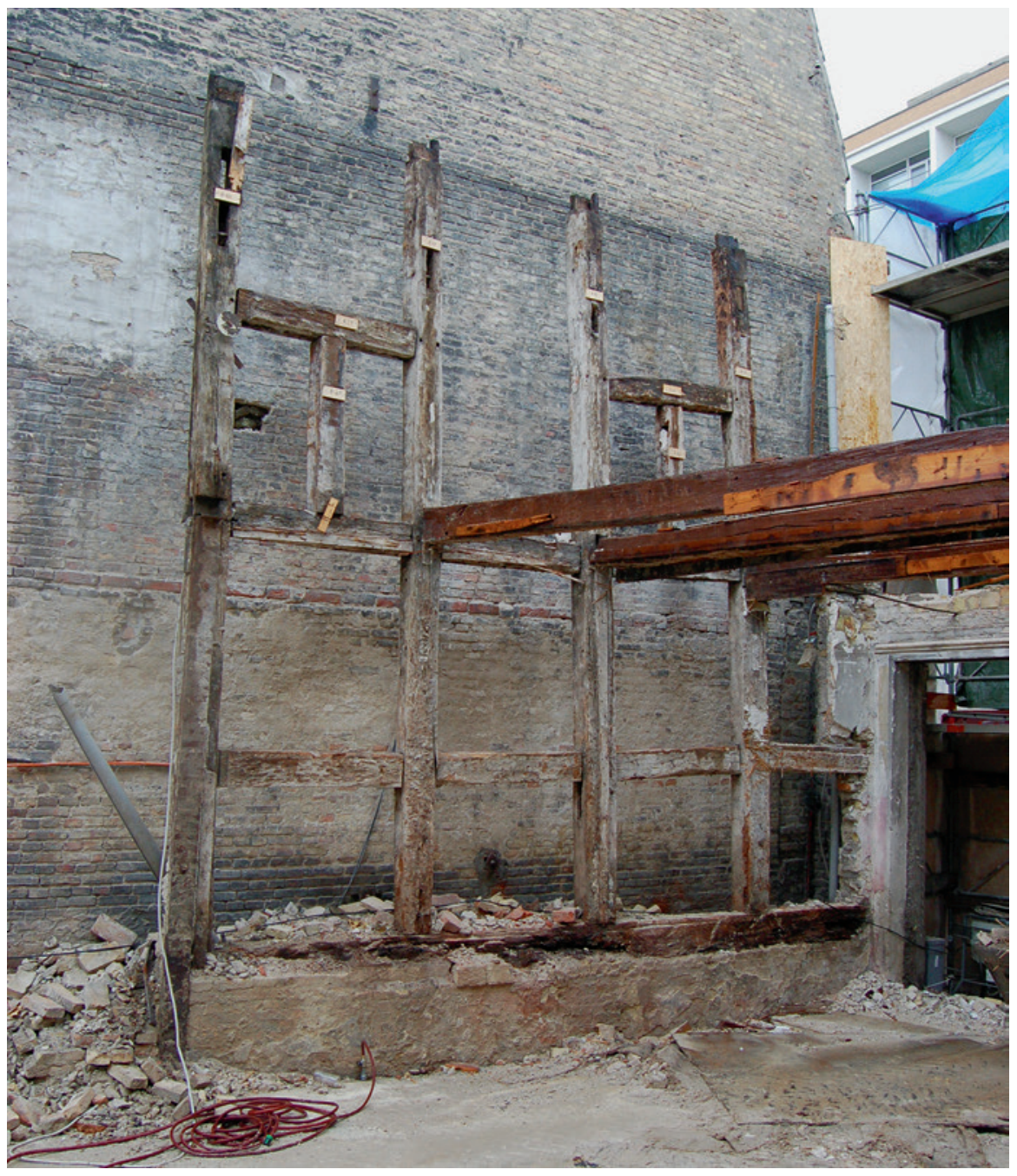

Fig. 27. Fra nedrivningen af hus A100 i 2007. Billedet viser de fire nordligste fag af vestvæggen set inde fra huset.

The demolition of house A100 in 2007. The picture shows the four northernmost bays of the west wall, seen from inside the building.

Alle samlinger var fornaglet med en enkelt gennemgående trænagle. Kun de gennemstukne bjælkeender var udvendigt fornaglet med to nagler.

Hele vestsiden var opført med højstolper, der alle var bevaret på nær den nordligste. Fagene var 1,4 m brede. Husets to bjælkelag var tappet gennem højstolperne. Desuden var der taphuller til indvendige kopbånd $15 \mathrm{~cm}$ under begge bjælkelag. Som nævnt var den østlige langside udkraget ved andet stokværk. Taphuller viste, at udkragningen var båret af knægte på ydersiden, og der var også her kopbånd på indersiden. Den øverste bjælke var som ved vestvæggen tappet gennem stolpen, også her var der kopbånd. Den oprindelige tagrem var 
bevaret i vest og delvist i øst, og huset havde et styrtrumsloft på $40 \mathrm{~cm}$. Hele fodremmen var i begge sider borte, så stolpernes oprindelige højde kunne ikke måles.

Vestsiden havde i hvert fag tre vandrette løsholter, der oprindeligt delte fagene i fire næsten kvadratiske tavl. Østsiden havde en løsholt i hvert stokværk. Taphullerne i stolperne viste, at vestvæggen oprindeligt havde enkelte skråstivere i første stokværk, og at østvæggen havde enkelte skråstivere i både første og andet stokværk. Flere tavl var ved nedrivningen delt af lodrette dokker, men de var alle sekundære. De var ikke tappet i løsholterne, og desuden dækkede de for de oprindelige støjlehuller. I oversiden af løsholterne var en udhugget rille, og i undersiden var der huller til støjler. Der var således ingen tvivl om, at begge langsider oprindeligt havde haft lerklinede tavl. Enkelte tavl havde stadig ved nedrivningen den oprindelige udfyldning. De fleste af tavlene var dog ved nedrivningen udmuret med moderne mursten. Kun fire af undertavlene i den vestlige væg var udmuret med munkesten, hvoraf mange var halve. Der var utvivlsomt tale om genbrugte sten. Alle havde et indstemplet aftryk, der viste, at stenene sandsynligvis var fremstillet i Lübeck, Gross-Wesenberg ved Trave. ${ }^{54}$

Sydgavlen stod ved nedrivningstidspunktet stadig i bindingsværk, men denne blev ikke undersøgt.

Kælderen under den nordlige del af hus A100 havde husets fulde bredde og var 4,3 meter i husets længderetning. Det svarede til husets tre nordlige fag. Kælderen var lav og havde en dybde på lidt mere end en meter under gadeniveau. Den var bygget i kampesten. Nedgangen til kælderen var fra Algade. Gulvet var et tyndt betongulv, der må have afløst et eller flere ældre gulve. Loftsbjælkerne vendte nord-syd og var af egetømmer med samme dimensioner som husets øvrige bjælker.

Huset havde utvivlsomt hovedindgangen i nordgavlen mod Algade. Foruden denne indgang var der to døre i østsiden. En dør i tredje fag fra nord i andet stokværk viser, at der har været en tilbygning på østsiden af huset op mod Algade. I tiende fag i første stokværk var, hvad der må have været en bagdør til gården.

Der blev ved nedrivningen ikke undersøgt, om der var spor efter skillevægge i husets første stokværk, men på grund af kælderen er det oplagt at tolke de forreste fire fag som et nordligt rum. De sydligste tre stolper i første stokværks østvæg blev opmålt, og her var der ikke spor efter skillevægge. En opdeling med yderligere en skillevæg skal da være fra sjette til ottende stolpe. I andet stokværk var der ingen spor efter skillevæge, der kan dog have været bræddevægge, som det kendes ved andre bindingsværkshuse fra samme periode. Bræddevægge ville ikke have sat sig bemærkelsesværdige spor. ${ }^{55}$

Indvendigt var væggene på nedrivningstidspunktet pudset. Der var på tømmeret sømmet diverse genanvendte træstykker. Et af disse var et panelstykke med påmalet skrift og spor efter lister. ${ }^{56}$ Det minder derved om et stykke fra en panelstue, som de kendes fra andre renæssancehuse. I en af de sydligste højstolper var der en lille deform blystump. Måske er der tale om en geværkugle, hvilket ikke vil være overraskende, da huset i tre generationer var beboet af bøssemagere i 1600 - og 1700 -tallet. ${ }^{57}$

Hus A100 blev dendrokronologisk dateret. Der blev fra husets tømmer udtaget seks prøver. Resultatet var entydigt. Dateringerne var efter 1536, efter 1547, efter 1557, efter 1563, 1573-1574 og ca. 1576. ${ }^{58}$ Prøven fra 1576 var fra kælderloftet og tilhører derfor ikke husets oprindelige konstruktion. Huset blev derfor bygget i år 1574 eller kort derefter. Huset stod på grunden i perioden 1574-2007. 


\section{NOTER}

Der skal lyde en særlig tak til Elisabeth Munksgaard Fonden for økonomisk støtte til udarbejdelsen af denne artikel!

1. Møller 2008, s. 200.

2. Jensen og Møller 2010, s. 100-103.

3. Jensen 2009, s. 27-28.

4. Strukturændringen ses blandt andet i ÅHM 4158 Bredegade 7.

5. Mårtensson 1976, s. 27-37.

6. Mårtensson 1976, s. 41-51.

7. Levin Nielsen 1969, s. 31-38.

8. Hansen 2015, s.90-92.

9. Klinge 2013, s. 120-123.

10. ÅHM 1239 Strandstien II (Algade 40), et eksempel; ÅHM 2481 Algade 19, et eksempel; ÅHM 4158 Bredegade 7, to eksempler; ÅHM 4439 Boulevarden etape 2, et eksempel med en lidt anderledes konstruktion og ÅHM 6488 Algade 33, et eksempel fra en profil.

11. Klinge 2013, s. 112 og 126-127.

12. Krongaard Kristensen 1987, s. 79-80.

13. ÅHM 5621 Algade 5. Fodremmen i konstruktionen blev dendrokronologisk dateret til 1424. Daly 2007, 5621X26 og 5621X60

14. ÅHM 4158 Bredegade 7: hvor der var en teglkælder fra 1400-tallet og to kampestenskældre fra midten af 1500-tallet; ÅHM 5457 Algade 3: hvor der var en teglkælder fra 1400-tallet og ÅHM 5750 Algade 5: hvor der var en kampestenskælder muligvis fra middelalderen.

15. ÅHM 4158 Bredegade 7: Den føromtalte teglkælder fra 1400-tallet erstattes efter midten af 1500-tallet af en kampestenskælder ud til gaden. ÅHM 5457 Algade 3: Den føromtalte teglkælder fra 1400-tallet erstattes i 1600-tallet af en ny teglkælder ud til gaden. Der er endnu ikke i Aalborg arbejdet med, hvorfor kældrene ændrer placering.

16. Søndergaard 1986, s. 15-22.

17. Engqvist 1986, s. 46-53.

18. Engqvist 1975, s. 55-56; Engqvist 1986, s. 47-48.

19. Engqvist 1968, s. 19-115. I værket omtales der i alt 20 bindingsværkshuse dateret til før år 1600.

20. Klinge 2013, s. 113 og 127-128; ÅHM 6483 Nørregade 25, hvor hele gulvniveauet i et hus fra 1400-tallet blev undersøgt i 2015.

21. Materialet må findes blandt de skifertyper, der i Kaupangmaterialet er henført til den Caledonske del af det norske grundfjeld - se Resi 2011, s. 374.

22. I artiklen Jensen \& Møller 2010 mangler hus A691 således som det ældste hus.

23. 5698X1746: England, Knud den Store, Pointed Helmet, North 787, 1024-1030, Ælfwine i Wallingford.

24. 5698X1499: Irland, fase III, SCBI 32, nr. 255, ca. 1035-1055. Og 5698X1639: Dinant, Dbg. 174, af Dannenberg på usikkert grundlag tilskrevet grev Albert III (10371105).

25. 5698X1941: Tilskrevet Jever, hertug Bernhard II (1011-1059). Dateres af Kilger med stor sandsynlighed til ca. 1010-1020, Dbg. 1298, Kilger Jev?B (s. 179). 5698X1942: Skandinavisk efterligning af engelsk mønt, starten af 1000-tallet. Mangler hos Hau- 
berg, Becker og Malmer. Forside sandsynligvis Long Cross buste, bagside Small Cross med cirkel. Halv.

26. AAR 12921, Report266, 2009 (5698R018). Der er anvendt en 68,2\% sandsynlighed.

27. Rapport FHM 4296/666, Konserverings- og naturvidenskabelig afdeling, Moesgaard Museum, 2008, 5698X2004 (5698R015).

28. AAR 12921, Report266, 2009 (5698R018). Der er anvendt en 95,4 \% sandsynlighed.

29. Roesdahl et al. 2014, s. 398.

30. Bonde 2012, 5698X1541 og 5698X964.

31. 5698X1499: Irland, fase III, SCBI 32, nr. 255, ca. 1035-1055.

32. 5698X1639: Dinant, Dbg. 174, af Dannenberg på usikkert grundlag tilskrevet grev Albert III (1037-1105).

33. 5698X1485: Muligvis Speyer, under Henrik III (1039-1056), Dbg. 830b-d, 1639-43, 2055-56. Og 5698X1456: Frisland, grev Bruno III (ca. 1050-), Dokkum, Ilisch 21.19 (el. evt. 21.20-22). Halv.

34. Bonde 2012, 5698X1536.

35. Bonde 2012, 5698X1503 og 5698X1501.

36. 5698X1337: Svend Estridsen, Lund, ca. 1060, Hbg. 28.

37. Moltsen 2010, s. 68.

38. Moltsen 2010, s. 68-71 og 75.

39. 5698X1337: Svend Estridsen, Lund, ca. 1060, Hbg. 28.

40. Bonde 2012, 5698X1521 og 5698X1509.

41. Moltsen 2010, s. 71

42. Moltsen 2010, s. 71-73.

43. Denne celleemaljefibel kommer fra det ældste gulvlag i hus A452. Den er én af blot to af denne type fibler, der er fundet i daterede lag. Baastrup 2009.

44. Bonde 2012, 5698X0479, 5698X0480 og 5698X0482.

45. Bonde 2012, 5698X0456, 5698X0457, 5698X0458, 5698X0460, 5698X0464 og $5698 \times 0465$.

46. Bonde 2012, 5698X062, 5698X0467 og 5698X0472.

47. Moltsen 2010, s. 74

48. Bonde 2012, 5698X0416, 5698X0424 og 5698X0425.

49. 5698X257: Sandsynligvis Stralsund, witten, før 1379, Jesse 310.

50. 5698X912: Kobbersterling, ca. 1420-35, Randers.

51. Liebgott 1971, s. $195 \mathrm{ff}$.

52. Engqvist 1986, s. 50-51.

53. Bonde 2012, 5698X0326 og 5698X0408.

54. Larsen 1986, s. 105.

55. Engqvist 1986, s. 48.

56. På planken stod der: ...OffNVNG [skilletegn] GLAVBE [skilletegn].

57. Værnfeld 1964, s. 155.

58. Hylleberg Eriksen 2007, 5698X0001, 5698X0002, 5698X0003, 5698X0005, $5698 \times 0027$ og 5698X0028. 


\section{LITTERATUR}

Bonde, N. 2012: Dendrokronologisk undersøgelse af tømmer fundet ved arkceologisk udgravning $i$ Algade 9, Aalborg. NNU Rapport 22. København.

Baastrup, M.P. 2009: Småfibler af karolingske og ottonske typer i Danmark. Aarbøger for Nordisk Oldkyndighed og Historie 2005, s. 209-255.

Daly, A. 2007: Algade, Aalborg. AHM 5621. Upubliceret rapport. (5621R004)

Engqvist, H.H. 1968: Aalborg bindingsverk. Aalborg.

Engqvist, H.H. 1975: Povl Pops Trefoldighedshus. Købstadsmuseet "Den gamle BY", s. 33-66.

Engqvist, H.H. 1986: Jyske gavlhuse. I: S.M. Søndergaard, P.K. Madsen, H.H. Engqvist \& O. Degn: Grønnegade 12 i Ribe. Ribe, s. 37-56.

Hansen, J. 2015: Landsbydannelse og bebyggelsesstruktur $i$ det 1. årtusinde - et bebyggelseshistorisk regionalstudie. Ph.d-afhandling afleveret 2015 ved Syddansk Universitet, Odense. Tilgængelig via www.academia.edu.

Hylleberg Eriksen, O. 2007: Dendrokronologisk undersøgelse af bindingsverk fra Algade 9, Aalborg. NNU rapportblad 2007. København.

Jensen, C.V. 2009: Vikingetid og middelalder i Algade 9 - den arkæologiske undersøgelse. Årsberetning 2008. Nordjyllands Historiske Museum, s. 19-29.

Jensen, C.V. \& S.B. Møller 2010: Algade 9 gør Aalborg ældre. Årsberetning 2009. Nordjyllands Historiske Museum, s. 99-105.

Klinge, C. 2013: Planløsninger og indretninger i træhuse fra Aalborg fra 1050-1600. Kuml, s. 107-143.

Kristensen, H. Krongaard 1987: Middelalderbyen Viborg. Århus.

Larsen, N.-H. 1986: Stemplede vingetagsten. Bygningsarkcoologiske Studier 1986, s. 101-110

Levin Nielsen, E. 1969: Pederstræde i Viborg. Købstadsarkæologiske undersøgelser i 1966/67. Kuml 1968, s. 23-81.

Liebgott, N.-K. 1971: Afstøbninger af pilgrimstegn på danske middelalderlige kirkeklokker. Aarbøger for Nordisk Oldkyndighed og Historie, s. 195-240.

Moltsen, A.S.A. 2010: Lag- og makrofossilanalyser fra Algade $9 i$ Ålborg (ÅHM 5698), NOK, Natur og Kultur, rapport nr. 21. Upubliceret rapport. (5698R031)

Møller, S.B. 2008: Aalborgs ældste tid: Perioden ca. 900-1200. I: H. Andersson, G. Hansen \& I. Øye (red.): De første 200 årene - nytt blikk på 27 Skandinaviske middelalderbyer. UBAS Nordisk, Universitet i Bergen Arkeologiske Skrifter 5. Bergen, s. 195-214.

Mårtensson, A.W. (red.) 1976: Uppgrävt förflutet för PKbanken i Lund. En investering i Arkeologi. Archaeologica Lundensia Investigationes de Antiqvatibus Urbis Lundae VII. Kulturhistoriska museet i Lund. Lund

Resi, H.G. 2011: Whetstones, Grindstones, Touchstones and Smoothers. I: D. Skre (red.): Things from the Town. Artefacts and Inhabitants in Viking-age Kaupang. Kaupang Excavation Project. Publication Series, Vol. 3. Norske Oldfunn XXIV. Oslo, s. 373-393.

Roesdahl, E., S.M. Sindbæk \& A. Pedersen 2014: Aggersborg i vikingetiden. Bebyggelsen og borgen. Nationalmuseet og Jysk Arkæologisk Selskab. Højbjerg.

Søndergaard, S.M. 1986: Bygningsarkæologisk undersøgelse og restaurering 1976-1983. I: S.M. Søndergaard, P.K. Madsen, H.H. Engqvist \& O. Degn: Grønnegade 12 i Ribe. Ribe, s. 9-25.

Værnfelt, K. 1964: Algade I Aalborg. Fra Himmerland og Kjer Herred, s. 149-188. 


\section{Algade 9 in Aalborg \\ Development of the settlement from the Viking Age to the present day}

In 2007, a half-timbered house dating from 1574 was demolished in the centre of Aalborg. In advance of the subsequent construction project, the Historical Museum of Northern Jutland excavated a $135 \mathrm{~m}^{2}$ area at the site. The cultural layers were up to $4 \mathrm{~m}$ in thickness and the dating frame extended from the Viking Age to 1574 . There proved to have been settlement on the site throughout this entire period, and one of the main results of the excavation was, consequently, a sequence of in all 19 buildings dating from the end of the 10th century to 1574 .

The site represents one of the best assemblages of urban buildings from the Viking Age and Middle Ages. The site was almost continually occupied by dwelling houses throughout the entire Middle Ages. The excavation findings therefore reflect developments in house morphology and internal organisation from the Viking Age until the early Renaissance. This article presents the excavation findings relating to the houses at the site.

The site was excavated stratigraphically and the excavated surface was recorded at 13 survey levels: The excavation plans presented in this article are digitalised, redrawn versions and interpretational levels. At one point, the excavation was very pressed for time and the houses from the period c. 1225-1350 in particular were affected by being excavated very rapidly. Machine excavation was, however, not employed.

For several of the earlier houses, up to two-thirds of the building lay within the excavation trench. It was therefore possible, in most cases, to investigate large parts of the houses' floor areas, and thereby demonstrate their internal organisation and layout.

The preservation conditions for organic material were good in the $4 \mathrm{~m}$ thick cultural layers at the site. Samples were therefore taken for dendrochronology from all suitable timbers and samples were taken for plant macro-remain analysis from the excavation sections.

Algade has been the main thoroughfare throughout Aalborg's history, and the town grew up around this street. For most of the Middle Ages, Algade 9 was a neighbour to the town's Franciscan monastery (fig. 1). The site's relatively large houses, situated on one of the town's most important streets, makes it likely that their occupants belonged to the wealthier part of Aalborg's population. Several finds, from all levels, can also be considered as high-status objects. Furthermore, the finds demonstrate contacts with an international trading environment, primarily in the form of imported ceramics, but also including other categories of finds.

The earliest dwelling houses at Algade 9 were built at the end of the 10th century. But they overlay earlier structures and features from the 8th and 9th centuries. From the end of the 10th century there is, accordingly, an almost unbroken series of habitations on the site, extending up to the present day (fig. 2). Of the 19 buildings, 17 were dwelling houses, with the two others being a byre and a smithy, respectively. The houses were primar- 
ily oriented with their north gable out towards Algade.

From the beginning of the 11th century there were two plots represented at the site, as the boundary was displaced c. 2 $\mathrm{m}$ to the east relative to the present-day cadastral boundary (fig. 3). In the mid13th century, the western plot was turned over to a churchyard, probably belonging to Aalborg's Franciscan monastery, which was founded in the 1240s. In the mid14 th century, the area was cleared and a brief period followed without dwelling houses on the site. During this short time span, byre A350 stood on the southern part of the plot (fig. 4). The monastery churchyard was also reduced. In general, a marked change took place in the structure of the plot, possibly the result of a brief reduction in population. The Black Death, or a famine resulting from the agricultural crisis of the 14th century, could have been the cause. Subsequently, it appears that the present plot division was re-established and gable houses were built on the site.

In the period c. 985-1075, five curvedwalled longhouses stood on the site: A691, A584, A657, A625 and A578 (figs. $5,15-17)$. Of the five houses, four were oriented north-south and not, as was the norm for this period, east-west. This is seen as a reflection of relatively dense settlement structure around these buildings. In the second half of the 11th century, houses became straight-walled, and during this period a curved-walled house and a straight-walled house stood side by side. This transition in the second half of the 11th century is also evident in Lund and Viborg.

The preserved timber and wood from the houses enables description of a number of constructional features. This applies in particular to the outer walls of the houses (fig. 6). There appears to have been two different constructional types.
Houses A584 and A691 have had stave walls, set in wall ditches, while houses A756, A625 and A587 had bole-like constructions. In the latter, the wall posts can be considered as double posts, because they consisted of two posts positioned closely together. The horizontal timbers occupying the spaces in between comprised cloven tree trunks with no further working. Their ends were though cut obliquely so they could be inserted into the gaps between the double posts (fig. 7). Houses A625 and A756 had external, sloping buttress posts. The angle of these revealed wall heights of at least about 2 $\mathrm{m}$. House A503, from the 12th century, also had external sloping buttress posts, but here the wall height proved to be less than $2 \mathrm{~m}$.

Various tree species had been employed in the curved-walled houses: oak, alder and birch timbers were observed. There had been some reuse of timber, which saw expression in the very different ages of dated timbers taken from the same wall.

In houses A756, A625 and A578 an internal division could be perceived in the form of a relatively large central room, flanked by smaller rooms at the gables (fig. 8). The hearths were found to be situated in this central room. This internal division and relatively slight construction corresponds in many ways to similar houses excavated in Lund and Viborg. Basically, these buildings can be perceived as variants of the so-called Trelleborg house. The date of this house type has previously been presented as c. 950-1050, something which the Algade 9 houses give no reason to adjust.

Houses A572, A504, A503, A452, A427, A428 and A376, which are dated to the period c. 1075-1350, had so many features in common that they probably represent a specific house type (figs. 17-21). The side walls were straight on all these buildings. 
They had three rooms, of which probably only the two northernmost ones, towards Algade, constituted living quarters. The rooms were connected by an internal door. The southerly, rearmost rooms were of unknown function. There was probably not internal access from the middle to the southern room (fig. 9).

The most striking common feature of the houses was that they had a jamb stove, which projected into the middle room of the building, but was fired from the northern room (figs. 10-11). Jamb stoves were observed in houses A504, A452, A427, A428 and A376. All the other hearths and fireplaces were in the room to the north too. The middle room had therefore offered a comfortable and smoke-free environment. It was of a more private character, because the only access was via the northern room. The jamb stoves found in the houses were all made according to the same pattern: A rectangular clay construction with an internal layer of stones immediately below the actual working surface. The stove cupula was then built up over a skeleton of withies that were pushed into the stove base.

On the basis of the findings from the Algade 9 excavation, the above house type has been identified at other sites in Aalborg and is very similar to some coeval houses excavated in Viborg. The evidence suggests that this was a common type of urban house in northern Jutland during the first half of the Middle Ages.

The latest houses on the plot, A221, A71 and A55, were probably halftimbered buildings, like the demolished house A100 (figs. 22-26). The houses were built using sill (foundation) stones and the latest had decayed traces of sill beams. In house A221, the sill was possibly founded using piles that were mortised into the sill beam's lower surface (fig. 12).
Houses A221 and A55 both had a cellar below their southern part. They were built of wood and had cobbled floors (fig. 13). A possible parallel to these houses with cellars is Grønnegade 12 in Ribe: This had a room over the cellar which functioned as a living room or hostel. The latter could also have been the case with the houses at Algade 9. The demolished house A100 from 1574 also had a cellar, but this was in the northern part of the building, out towards Algade.

There is evidence to suggest that houses A221 and A55 had an internal organisation, which corresponded to a northern Jutland pattern seen in several gable houses from the 16th century in Jutland. This type of internal organisation is characterised by very few rooms and the room out towards the street functioning as the entrance hall/anteroom. The kitchen hearth was in the living room behind this anteroom. In houses A221 and A55 at Algade 9 there were no definite traces of dividing walls between the two foremost rooms. But there were hearths in both houses in what was probably the second room in from the street (fig. 14). Fragments of tiles from a tiled stove were found in these two houses. From the results of several other excavations in Aalborg, it can be seen that the northern Jutland layout was probably common in the town as early as the end of the 14th century.

The almost continual occupation of the site over such a prolonged period provides an insight into developments in the building stock on a plot in the centre of a Medieval market town. It can be debated how representative this development is, but parallels have been presented which suggest that, when it comes to the internal layout of the houses, types are present that can possibly be recognised in other parts of Denmark. Consequently, these houses may perhaps represent general 
patterns in housing for ordinary tradesmen and merchants through the Middle Ages. The main aim here, however, has been to present the excavation findings and thereby create a foundation for these comparisons. At the time of the excava- tion in 2007 there was a lack of published information on Medieval houses that could help us to understand the excavated building remains. The present article is an attempt to redress this situation.

Christian Vrengmose Jensen

Christian Klinge Nordjyllands Historiske Museum 